Portland State University

PDXScholar

$1-1-2011$

\title{
The Binfords and Mort Publishing Company and the Development of Regional Literature in Oregon
}

Jeremy Skinner

Portland State University

Follow this and additional works at: https://pdxscholar.library.pdx.edu/open_access_etds

Let us know how access to this document benefits you.

\section{Recommended Citation}

Skinner, Jeremy, "The Binfords and Mort Publishing Company and the Development of Regional Literature in Oregon" (2011). Dissertations and Theses. Paper 156.

https://doi.org/10.15760/etd.156

This Thesis is brought to you for free and open access. It has been accepted for inclusion in Dissertations and Theses by an authorized administrator of PDXScholar. Please contact us if we can make this document more accessible: pdxscholar@pdx.edu. 
The Binfords \& Mort Publishing Company and the Development of Regional Literature in Oregon

\author{
by \\ Jeremy Skinner
}

A thesis submitted in partial fulfillment of the requirements for the degree of

Master of Arts

in

History

Thesis Committee:

David Johnson, Chair

Carl Abbott

William Lang

Caroline Litzenberger

Portland State University

(C)2011 


\section{ABSTRACT}

During the first half of the twentieth century there was a flourishing of publishers in the United States that specialized in books with content targeted for regional audiences. One of the largest regional publishers west of the Mississippi was the Binfords \& Mort publishing company of Portland, Oregon. In 1930, Binfords \& Mort began publishing works of fiction, history, poetry, children's literature, and natural history by Pacific Northwest authors with content focused on the Pacific Northwest. Between 1930 and 1984, when the Binford family sold the publishing company, Binfords \& Mort published around one thousand titles, and became a one of the leading influences on the Oregon literary scene. Although Binfords \& Mort did not publish books that received widespread critical praise from national literary critics, its books sold well to Oregon readers. This thesis examines the economic and cultural contexts for Binfords \& Mort, and its larger cultural impacts. The thesis also challenges the standard claim that Oregon literature underwent a major shift toward modernism after the publication of H.L. Davis's and James Stevens's critique of Oregon writing, Status Rerum in 1927. Instead, the thesis proposes that by looking at the output of Oregon's most popular publisher, Binfords \& Mort, one finds that an older style of writing focused on the pioneer period continued to be popular well into the twentieth century. These publications had a widespread impact on Oregon's cultural development. 


\section{ACKNOWLEDGMENTS}

This project benefited from the generosity of many. David Johnson, Jim Kopp, Paul Merchant, and Doug Erickson in particular were persistent in encouraging, teaching, providing me with sources, reading drafts, and shaping my ideas.

At Portland State University my thesis defense committee, including David Johnson, Carl Abbott, William Lang, and Caroline Litzenberger provided me with thoughtful suggestions necessary to complete this project.

Antiquarian booksellers, including John Henley (Portland), Charles Seluzicki (Portland), Elisabeth Burdon (Portland), Mark Wessel and Michael Lieberman (Seattle), Scott Givens (Albany and Corvallis), and Roger and Ilse Roberts (Portland) were indispensable in uncovering sources.

Numerous librarians provided essential access to research materials, including Gay Walker at Reed College, the University of Oregon Special Collections staff, Brian Johnson at the City of Portland Archives, the Oregon Historical Society staff, Jim Carmin at the John Wilson Room, the University of Washington Special Collections staff, and my own colleagues at Lewis \& Clark College.

Over the past ten years I have benefited from the friendship of a number of people who have challenged my ideas and engaged in thoughtful conversations about various aspects of this project. These individuals include Peter Kopp, Steve McQuiddy, David Milholland, Ralph Mort, Charles Seluzicki, Peter Sleeth, William Talbott, and Jean Ward.

Finally, thanks to Phoebe Skinner, who has lived with and supported this project since its conception. 
TABLE OF CONTENTS

ABSTRACT $\ldots \ldots \ldots \ldots \ldots \ldots \ldots \ldots \ldots \ldots \ldots \ldots \ldots \ldots$

ACKNOWLEDGMENTS $\ldots \ldots \ldots \ldots \ldots \ldots \ldots \ldots \ldots$ ii

LIST OF TABLES $\ldots \ldots \ldots \ldots \ldots \ldots \ldots \ldots \ldots \ldots$. . . . . . . . .

GLOSSARY OF BOOK AND PUBLISHING TERMINOLOGY $\ldots . . \mathrm{v}$

A NOTE ON SOURCES \& TERMINOLOGY .............

I. INTRODUCTION $\ldots \ldots \ldots \ldots \ldots \ldots \ldots \ldots \ldots \ldots \ldots$

II. THE BEGINNINGS OF PUBLISHING IN OREGON. . . . . . . 7

III. READERS AND WRITERS IN OREGON $\ldots \ldots \ldots \ldots \ldots \ldots . . .32$

IV. THE BINFORDS \& MORT PUBLISHING HOUSE ......... 56

V. THE BINFORDS \& MORT LITERARY SENSIBILITY . . . . . . . .85

VI. CONCLUSION: A PUBLISHER'S LEGACY ............. 113

REFERENCES

UNPUBLISHED SOURCES CITED . . . . . . . . . . . . 120

PRINT \& ONLINE SOURCES CITED. . ................ 121

BINFORDS \& MORT WORKS CONSULTED. ..............135 


\section{LIST OF TABLES}

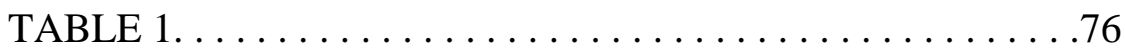




\section{GLOSSARY OF BOOK AND PUBLISHING TERMS}

Binding - The cover of the book.

Blind stamping - An impressed mark, decoration, or lettering, not colored or gilded, usually appearing on the binding. One way that the Book Clubs have marked their editions when they are otherwise identical to trade editions is to use a small square, round, or sometimes leaf-shaped blind stamp in the bottom right corner of the rear board.

Blurb - A comment from a review (often by another author praising the particular book) printed on the dust wrapper or covers of a proof copy, or on a wrap-around band.

Boards - The stiff binding material for most modern books.

Book Block - The entire book sewn together before it is bound.

Bookplate - A pasted-in sign of ownership. Modern bookplates are pressure sensitive (peel-and-stick) as opposed to the older bookplates, which were made with wateractivated adhesive (lick-and-stick). Some bookplates from the last century were quite elaborate with engravings.

Bound - A book with a cover of any type, or a periodical that has a cover other than its published wraps.

Broadside - A single sheet of paper, usually printed on one side only.

Buckram - A heavy linen cloth used in book binding. It is often starched or coated with some protective material.

Case-Bound - The book is hardbound as opposed to a paperback.

Cloth - A cloth-bound book. The covering can be linen, buckram or another textile.

Colophon - An identifying inscription or emblem from the printer or publisher appearing at the end of a book. Also the emblem at the bottom of the spine on both the book and dust-wrapper as well as a logo on the title or copyright page.

Covers - The binding of the book, particularly the front and back panels of the book.

Decorative Stamped Binding - A highly detailed impression stamped into the cover and/or spine of a book. 
Dedication Copy - The copy of the book inscribed by the author to the person to whom the book is dedicated.

Device - A printer's ornament. Also an insignia that is the publisher's identifying mark. Now interchangeable with Colophon.

Dummy- A mock-up of a book used by salesmen in the late $19^{\text {th }}$ and early $20^{\text {th }}$ century to show prospective buyers what the book would look like. It usually had a title page, 10 or 20 pages of text, and then blank pages to fill out the rest of the binding.

Dust Jacket - A term synonymous with Dust Wrapper, indicating the usually decorative paper wrapper placed around a book to protect the binding.

Edition - All the copies of a book printed from the same plates or typesetting.

Editor- A person who gathers material for a book, oversees text written by others, and/or makes the text more readable.

End Papers- The sheets of paper pasted onto the inner covers, joining the book block to the covers. One side of the sheet is pasted to the inside cover, the other is left free.

Ephemera - From the Greek work ephemeron, meaning something that disappears quickly. Examples are: manifestos, broadsides, programs, menus, tickets, playbills, etc.

Errata - Mistakes or errors. Generally encountered in the term "errata slip," a small sheet of paper laid into a book by a publisher who has discovered errors prior to publication.

First Edition - Generally used by book dealers and collectors to mean the first appearance of a work in book or pamphlet form, in its first printing.

First Trade Edition - The edition produced for general commercial sale, as distinguished from a limited edition.

Half-Title - The page carrying nothing but the title of the book, usually preceding the title page.

Impression - A much misused term, but one that, when accurately employed, means the number of copies printed during any given press run.

Imprint - A term that can refer either to the place of publication or to the publisher.

Incunabula - Books, pamphlets, calendars, and indulgences printed before 1501 .

Index- An alphabetical listing of names or topics mentioned in the book, with their page 
numbers. For serials and journals, the index is usually published after the volume is completed and is usually found in the last issue.

Inscribed - Usually indicates a book signed by the author, either with an inscription to a specific person or bearing some brief notation along with his signature.

Issue - Synonymous with State, referring to the priority of copies within the first edition.

Jacket - The printed or unprinted cover, usually paper, placed around the bound book. Sometimes called Dust Jacket (dj), Dust Wrapper (dw), dust cover or book jacket.

Juveniles - Books originally or primarily written to be read by (or to) children.

Laid Paper - A handmade paper showing parallel lines of the papermaking frame, visible when held up to the light.

Leaf - A single sheet in a book; each leaf contains two printed pages, one on each side.

Limited Edition - Any book whose publication is deliberately restricted to a small number of copies, usually numbered and often signed by the author and/or illustrator.

Marbled - Paper decorated with an imitation marble pattern.

Monograph - A work, generally short, dealing with a single subject and usually issued in pamphlet form.

No Date - No date of publication mentioned within the book.

No Place - No place of publication listed in the book.

Octavo (8vo) - A book of about five inches wide and eight inches tall to about six by nine inches. Octavo is the most common size for current hardcover books. To make octavo books, each sheet of paper is folded to make eight leaves (16 pages).

Offprint - A separate printing of a section of a larger publication; i.e., a periodical.

Page - One side of a leaf. The front side of a leaf is called the recto or obverse and the back side of the leaf is called the verso or the reverse.

Paperback - Books in paper wraps published since the 1930's, although it can describe any book with a paper cover.

Paper Boards - Stiff cardboard covered in paper. 
Perfect binding - Used in paperback books, trade paperbacks and magazines that have too many pages to be stapled. The page edges are glued together, and then placed in the covers. This is a less expensive process than traditional book binding and stapling.

Pictorial - Describes a book with a picture on the cover.

Plates - Whole-page illustrations printed separately from the text. Illustrations printed in the text pages are called cuts.

Printed Cover - Used to describe a dust wrapper or paper cover that is only lettered.

Printing - Another word for Impression.

Provenance - The history of ownership or possession of a given book.

Publication Date - The date a book is formally placed on sale.

Recto - The front side of a leaf in a bound book; in other words, the right-hand page of an opened book. Also called the Obverse.

Signature - In bookmaking, this does not mean the author's name written out in his hand. It refers rather to the group of pages produced by folding a single printed sheet, ready for sewing or gluing into a book.

Slipcase - A cardboard case covered in paper, cloth or leather, which holds a book with only the spine exposed.

Spine - book's backbone, where the signatures are gathered. The spine is covered with the backstrip.

State - Closely allied to the definition of Issue. State generally refers to a change other than a correction of a misprint.

Title Page - The title page, near the beginning of the book, lists the title and subtitle of the book, the authors, editors, and/or contributors, the publisher or printer, and sometimes the place and date of publication. The title page information should be used for cataloguing (not the half-title page or covers).

Uncut- The pages of the completed book have not been shaved down to a uniform surface.

Unpaginated - The pages are not numbered (although each signature may be designated by letter). 
Variant - A book that differs in one or more features from others of the same impression, but a positive sequence has not been established.

Vellum- A thin sheet of specially prepared skin of calf, lamb, or kid used for writing or printing, or for the cover.

Verso - The second, or rear, side of a leaf in a book; in other words, the left-hand page of an opened book. Also called the Reverse.

Wrappers - The outer covers of a paperbound book or pamphlet. Not to be confused with Dust Wrapper. 


\section{A NOTE ABOUT THE SOURCES AND TERMINOLOGY}

Researching the history of regional publishing in Oregon presented some difficult challenges. Initially I was unable to find any archival collections that focused on Oregon's most successful regional publisher, Binfords \& Mort. Fortunately, the company was documented in Portland newspapers and printing trade journals. The University of Oregon possessed the personal papers of many of Binfords \& Mort's key authors and editors, including Alfred Powers, Ethel Romig Fuller, and Ben Hur Lampman. I also benefited from a 1955 University of Washington library science master's thesis on Binfords \& Mort's children's literature by Leona Jacob Ayres, which included information from an interview with one of the second-generation owners of the company.

After piecing together a rudimentary history of the company from these initial sources, I sought out corporate records. In 1983 the Binford family sold the company to James Gardenier of Portland, Oregon, whose family still owns the company. I approached Polly Gardenier to ask for access to the corporate records, and she informed me that she did have them, but citing a staffing shortage and privacy concerns she firmly turned away my proposal to use the records for research.

Denied access to corporate records, I turned to libraries and bookstores where I examined Binfords \& Mort's publications. Colophons, title pages, paper stock, illustrations, bindings, and textual content provided valuable information. During this phase of my research, John Henley of Great Northwest Books connected me with company associates, including one of the Binfords' salesmen and a Marylhurst University development officer who had been a close acquaintance of one of the Binfords' key 
editors. Henley also acquired publisher's catalogs that helped me understand how Binfords \& Mort marketed their books.

Another local book dealer, Elizabeth Burden, informed me that Reed College had an unpublicized collection of books and other materials relating to the company, which had been donated by Janet Binford, a Reed alum and long-time librarian and the last member of the Binford family to own the company. Janet Binford was the daughter-inlaw of Peter Binford, the co-founder of the company. Over the years, Janet had collected materials to document the history of the company. Access to the Binford collection at Reed College allowed me to complete this thesis, a first step toward the comprehensive history of regional publishing in Oregon that can only be written when the Binfords \& Mort corporate archives are made available for research.

Publishing is a field with a specialized vocabulary that will be used throughout this paper. Terms that are particularly confusing have been defined in footnotes. A glossary of publishing, printing, and bibliographic terminology has also been included. Knowing what term to use when describing the Binfords \& Mort Company was a challenge, since its name changed more than once. From 1891 to 1930 , the company worked as a job printer under the name Metropolitan Press, and in 1930 the company expanded its operations to include publishing. For this period, the term Metropolitan Press will always be used to refer to the company's job printing operations, while the term Metropolitan Publishing Company will be used to refer to its publishing activities. Occasionally the term "the Binfords" is used to describe the collective activities of the two owners of the company, Peter and Maurice Binford. In 1937 the company changed 
the name of its publishing operation to Binfords \& Mort, while keeping the Metropolitan Press name for its printing operation. Each of these terms is used to describe its respective operation. Finally, the company changed its name to Binford (singular) \& Mort in 1974 when Thomas Binford bought out the stock of the other Binford family members. This term is used when referring to the company after 1974. When writing in general terms about the company, the shortened version Binfords, or the formal name Binfords \& Mort is used, since this name was used during the key years of the company's activity. 


\section{INTRODUCTION}

On the corner of Ninth and Couch Streets in Northwest Portland stands a threestory building from the 1920s adorned with Corinthian columns and the title "Graphic Arts Building" centered above its third story windows. True to its name, the building has been the home to numerous graphic artists over its ninety-year history, including printers, advertisers, engravers, and most recently the Portland filmmaker Gus Van Sant, but forgotten are the days when this building was the publishing hub of Oregon literature.

For a fifty-year period from 1921 to 1971, the publishing company known as the Metropolitan Press, and later Binfords \& Mort, operated a thriving business focused on works of Pacific Northwest history, fiction, natural history, juvenile literature, and poetry. Working out of the Graphic Arts Building, Binfords \& Mort fostered the careers of hundreds of Oregon authors and issued nearly one thousand books.

At a time when a handful of Oregon authors like H. L. Davis and James Stevens were striving for acceptance by east coast critics like H. L. Mencken, Peter and Maurice Binford took a more modest approach to presenting Oregon writing to the world. Working closely with Alfred Powers, the writer and director of the University of Oregon extension program, the Binfords created a publishing program that specialized in books by Oregon authors and books about Oregon. Although most of these books were never considered literary masterpieces, they were eagerly read by Oregonians, who found comfort in writings about their romanticized past and took pride in works that drew attention to Oregon. While publishers across the country failed during the economic hardships of the Great Depression, Binfords \& Mort thrived, eventually growing to be 
one of the largest publishers west of the Mississippi, all while catering to a primarily local audience. From 1930 to 1980, Binfords \& Mort published over 1,000 books and cast a large shadow over all kinds of social developments in Oregon from literary societies to civic engagement. ${ }^{1}$ Their publishing program thrived for its first thirty years and then declined over its next forty, but during its heyday, the company's publishing efforts were the lynchpin of Oregon literature.

Discussions of the intellectual development of twentieth century Oregon literature have ignored the popularity of locally published regional books and the importance of Binfords \& Mort. The standard version of the intellectual history of Oregon creative writing has tended to focus on works that received national critical acclaim, rather than books that were widely read, regardless of literary quality. Most literary scholars have described Oregon as a literary backwater until James Stevens, the author of the first collection of Paul Bunyan tales, and H. L. Davis, the Pulitzer Prize winning author of Honey in the Horn, burst onto the scene in the 1920s. Oregon literary scholar and general editor of the Oregon Literature Series (Oregon State University Press, 1993-1994), George Venn, described the early years of Oregon literature as being made up of three distinct stages. ${ }^{2}$ During the first stage writers described their encounters with a foreign territory. Venn dates this period as lasting from 1781 to 1868 . The second stage, from 1868 to 1919 , saw writers attempting to name and catalog the environment in the

\footnotetext{
${ }^{1}$ No other Oregon publisher even came close to producing the quantity of books issued by Binfords \& Mort. For comparison, the Oregon Historical Society, which was the second most prolific publisher in Oregon, only issued 144 titles between the years 1953 and 2006. Most Oregon publishers contemporary with Binfords \& Mort issued no more than ten books.

${ }^{2}$ Edwin R. Bingham and Glen A. Love, eds., Northwest Perspectives: Essays on the Culture of the Pacific Northwest (Eugene, OR: University of Oregon, 1979), 99-118.
} 
languages of the lands from which they immigrated, or as H.G. Merriam put it, in terms that came from "Greenwich Village dirt or Mid-west loam" rather than the rocky ground of the Pacific Northwest. ${ }^{3}$ The third stage started in the 1920 s when writers began to respond to their environment and describe it in regionally authentic ways. Venn claims that this third stage was marked by the publication of Status Rerum, Stevens's and Davis's critique of the "tripe" being produced by Pacific Northwest writers. ${ }^{4}$

Venn was not alone in his assessment of Status Rerum as a crucial publication.

Almost every other scholarly study of Oregon literature has pointed to Status Rerum as marking the transition of Oregon's literature to an original voice. An Anthology of Northwest Writing: 1900-1950 published by the Northwest Review Books in 1979, and Varieties of Hope: An Anthology of Oregon Prose published by Oregon State University Press in 1993, both reprinted Status Rerum. In Varieties of Hope Gordon Dodds claimed that Status Rerum "probably had the greatest influence on Pacific Northwest literature..." and "inspired younger authors to write more honestly about their region."

The importance of Status Rerum has been overstated. ${ }^{6}$ The eight page staplebound pamphlet was only printed in an edition of two hundred copies, most of which

\footnotetext{
${ }^{3}$ H. G. Merriam, "Editorial," The Frontier 8 (1927): 1. Venn chose 1919 as the end date for this period because it was the year H. G. Merriam established The Frontier, a magazine at the University of Montana dedicated to indigenous literary expression. Although short-lived, Oregon supported a number of similarly ambitious literary journals during this period including: Tumbleweed (Portland, OR, 1939-41); The Literary Monthly (Portland, OR, 1933-34); The Outlander (Portland, OR, 1933-34); and Northwest Literary Review (Portland, OR, 1935).

${ }^{4}$ H. L. Davis and James Stevens, Status Rerum: A Manifesto Upon the Present Condition of Northwestern Literature, Containing Several Near-libelous Uttrances, Upon Persons in the Public Eye (The Dalles, OR: Printed Privately for the Craft, 1927).

${ }^{5}$ Gordon Dodds, ed., Varieties of Hope: An Anthology of Oregon Prose (Corvallis, OR: Oregon State University Press, 1993), 100.

${ }^{6}$ Other examples of this interpretation and explanation of the importance of Status Rerum can be found in: Warren L. Clare, “'Posers, Parasites, and Pismires': Status Rerum, by James Stevens and H. L. Davis," Pacific Northwest Quarterly 61 (1970): 22-30; Glen A. Love, "Stemming the Avalanche of Tripe," in
} 
were mailed to regional newspapers and writers and promptly thrown in the trash. ${ }^{7}$ Today there are only eight surviving copies of the original in libraries. ${ }^{8}$ The pamphlet was not reprinted until the 1970s; few writers, likely, read Status Rerum. There is little doubt that Status Rerum and Stevens' and Davis's subsequent writings possessed literary qualities that differentiated them from the rest of the literature in the Pacific Northwest, but it seems unlikely that Status Rerum would have, in the words of Love and Booth, "accomplish[ed] its aims, blasting to rags and pulp the record of mediocre gentility in Pacific Northwest literature and signaling the region's first step toward recovery from a near terminal case of high-mindedness."9

A study of the history of Binfords \& Mort puts this theory in proper perspective. The authors that met the standards for regional literature put forth by Stevens and Davis in Status Rerum were Stevens and Davis. The two also happen to be the main examples provided by Venn and the other anthologists for the emerging voice of Pacific Northwest literature. Both Davis and Stevens had books published in New York that received high praise from literary critics, but the majority of Oregonians continued to write about the State in stilted language that lacked life and creativity. With the emergence of Binfords \& Mort as a local publisher willing to publish almost anything with local flavor, there was little incentive for writers to attempt to write to the standards of Davis and Stevens.

Collected Essays and Short Stories by H. L. Davis (Moscow, ID: University of Idaho Press, 1986), 321-40; Brian Booth and Glen Love, eds., Davis Country: H. L. Davis's Northwest (Corvallis, OR: Oregon State University Press, 2009), 14-15; George Venn, "Continuity in Northwest Literature," in Bingham and Love, eds. Northwest Perspectives, 99-118; Lars Nordstöm, "The Growth of Regionalism in the Early Poetry of the American Northwest," Studia Neophilogica 57 (1985): 191-201; and Harold Simonson, "Pacific

Northwest Literature-Its Coming of Age," Pacific Northwest Quarterly 71 (1980): 146-51.

${ }^{7}$ Clare, "'Posers, Parasites, and Pismires,"” 22-30.

${ }^{8}$ WorldCat, www.worldcat.org.

${ }^{9}$ Booth and Love, eds., Davis Country, 14-15. 
Occasionally a Binfords \& Mort author like Archie Binns or Nard Jones would garner national attention and be credited with an authentic Pacific Northwest voice, but the notion of a literary revolution in response to Status Rerum just does not hold up when one looks at the massive number of Binfords \& Mort's publications that Davis and Stevens would have considered inferior. These books sold well and were widely read within the Pacific Northwest because they featured recognizable settings and personalities, capitalized on the nostalgia of Oregonians who grew up during the pioneer period, and gave the reader a sense of belonging to a place of importance. They may not have possessed the qualities literary scholars desired, but they cannot be ignored. The works of H. L. Davis and James Stephens were exceptional, whereas the works of Binfords \& Mort authors like Ben Hur Lampman and Elizabeth Lambert Wood were the norm. These were not necessarily bad books, but their existence and the publishing record of Binfords $\&$ Mort make a compelling case that Oregon literature did not undergo a revolution in the 1920s. Oregon literature became more popular and more widely available, but its quality and intellectual underpinnings evolved gradually, and may have even been stunted by lack of editorial pressure that was inherent in Binfords \& Mort's willingness and desire to issue almost anything written about the Pacific Northwest.

To understand the significance of regional publishing in Oregon and the role played by Binfords \& Mort, this thesis begins with an examination of the development of the publishing industry in Oregon, where newspapers, magazines, and job printers were the primary publishers of Oregon literature until the early years of the twentieth century when job printers began to recognize the market for regional literature and Binfords \& 
Mort established itself as Oregon's largest publisher. The history of the publishing industry in Oregon is crucial to understanding why regional publishing was viable as an industry, and why the Binfords were able to start a publishing company in the midst of the Great Depression. While market factors made regional publishing potentially viable, cultural influences on readers and writers in Oregon made regional publishing successful in Oregon. These influences, including demographic factors and national cultural movements like the arts and crafts movement, are examined in the second chapter. Although Oregon was enthusiastic for regional literature, the state was only large enough to support one major regional publisher, which was Binfords \& Mort. The third chapter tells the story of the emergence of Binfords \& Mort as Oregon's primary regional publisher, while the fourth chapter focuses on the literary contributions of Binfords \& Mort and their authors. The final chapter assesses the overall influence of the Binfords \& Mort regional publishing endeavor. 


\section{THE BEGINNINGS OF PUBLISHING IN OREGON}

In the years leading up to 1930 and the founding of the Metropolitan Press as a regional publishing firm, there were a number of economic and social changes in Oregon that helped create an environment ideal for successful regional publishing. Key among these changes were the slow and steady growth of the local printing and publishing industry, the development of a literate population interested in cultivating a distinct regional identity, population growth, transportation and communications improvements, and the growth of a thriving paper industry.

The first stage in the development of the publishing industry in the Oregon was the establishment of newspapers. Unlike twentieth century newspapers, which were primarily filled with daily news, newspapers from the mid-nineteenth century in Oregon were rich in literary content. In fact, in the 1840s and 50s it was considered a matter of national importance to publish "native" writings that were not tainted by foreign ideas in newspapers and magazines. ${ }^{1}$ By the 1840 s, newspapers had become a crucial part of the lives of people throughout the United States. Newspapers provided a sense of national cohesiveness by allowing readers across a diverse territory to share information. Both settlers and boosters saw thriving newspapers as crucial to the success of new communities in the American West. This dynamic is best articulated by Barbara Cloud in The Business of Newspapers in the Western Frontier, where she notes:

The mountain men of the nineteenth century sought to escape civilization by disappearing into the wilds of the West. Those who came later, to mine, farm, ranch, or otherwise take advantage of the regions rich natural resources sought instead to establish civilization where none had been before. Indeed, could they

\footnotetext{
${ }^{1}$ Ann Fabian, "Amateur Authorship," in A History of the Book in America: The Industrial Book, 18401880, ed. Scott E. Casper (Chapel Hill, NC: University of North Carolina Press, 2007), 409.
} 
have tucked a bottle of instant-civilization elixir amongst their underwear when they packed for the westward journey, they no doubt would have done so. Lacking a magical potion, however, they looked to one of the most used conduits through which such influences could flow: the newspaper. ${ }^{2}$

Newspapers were always the first stage in the development of a local publishing industry for the reasons mentioned above, and for the simple fact that newspaper businesses were much less expensive to establish than book publishing firms, or even job printing offices. Newspaper publication required a minimum of equipment. A printer, an ink roller, a set of type, and ink was the extent of the initial investment. Low quality, newspaper grade paper could be purchased at far cheaper rates than book paper, and newspapers did not require any sewing or binding, an aspect of book publishing that required additional equipment or expensive sub-contracting. ${ }^{3}$

The cost of equipment and supplies was not the only economic consideration. Newspapers sales also held less risk for investors. Because the per-unit cost for newspapers was so low, print runs could be easily adjusted to accommodate subscription demands without a significant impact on the production costs. As a result newspaper publishers did not have to carry expensive back stock. Book publishers had a much more difficult distribution problem. Because costs per unit were so much higher, it was rare for

\footnotetext{
${ }^{2}$ Barbara Cloud, The Business of Newspapers on the Western Frontier (Reno, NV: University of Nevada Press, 1992), 3.

${ }^{3}$ Edward L. Glaeser and Claudia Goldin, Corruption and Reform: Lessons from America's Economic History (Chicago, IL: University of Chicago Press), 210. According to Glaeser and Goldin, excluding importation fees the average cost of newsprint in the United States from 1840 to 1870 was $\$ 25$ per pound, which equaled approximately one cent for a four-page newspaper. Paper for book publication started at the same price and increased according to quality (usually judged by percentage content of linen). See also: Alfred M. Lee, The Daily Newspaper in America: The Evolution of a Social Instrument (New York, NY: Macmillan, 1937); and the National Bureau of Economic Research (NBER) Macro History Database, wholesale price of newsprint paper, Series m04093a,b, http://www.nber.og/databases/macrohistory/contents/chapter04.html.
} 
a complete print run to be pre-sold. Book publishers usually had to carry stock over the course of multiple years, meaning that annual profit margins were much smaller.

Finally, newspapers had the advantage of revenue streams not regularly available to book publishers in the form of advertising and sponsorship. Frontier newspapers in particular capitalized on civic pride and boosterism, publishing so many advertisements, that there was often little room for news. The Gold Hill Daily News of Nevada (October 12, 1863) published the following disclaimer in its first issue:

UNEXAMPLED PRESSURE. -We have been 'out-generaled' in all our plans for the first issue of the News by the singular kindness of our advertising patrons. The pressure upon us in this respect is unexampled in our knowledge of newspaper starting, and it has driven us to the exclusion of several arrangements with which we had intended to occupy our columns. ${ }^{4}$

Given these economic realities, it is not surprising that the first profitable printing operations in Oregon were newspapers. In 1845 a group of Willamette Valley investors established the Oregon Printing Association, the first for-profit publisher in the Pacific Northwest. The purpose of this organization, according to its constitution, was to "promote science, temperance, morality, and general intelligence; to establish a printing press; to publish a monthly, semi-monthly or weekly paper in Oregon ..." Officers of the Association included: William G. T'Vault, president; J.W. Nesmith, vice president; John P. Brooks, secretary; George Abernethy, treasurer; and Robert Newell, John E. Long, and John R. Couch, directors. Oregon City, the first significant settlement of the

\footnotetext{
${ }^{4}$ Cloud, The Business of Newspapers, 52.

${ }^{5}$ Oregon Printing Association Records, MSS-950, Oregon Historical Society; and George Himes, "History of the Press of Oregon 1839-1850," The Quarterly of the Oregon Historical Society 3 (1902): 336 . The constitution of the Oregon Printing Association is published in the Oregon Spectator, February 5, 1846.
} 
region, was the location of the OPA's newspaper, which would be called the Oregon Spectator. $^{6}$

It is clear from the first issue of the Spectator on February 5, 1846, that there were already a number of available creative and expository writers in the territory. Cultivating this writing community and introducing its products to a wider audience was an important role for the Spectator and other Oregon newspapers in developing the local publishing economy.

Without easy access to national news, and with a shortage of local news, the fourpage paper filled its pages with fictional and historical writings by local authors. ${ }^{7}$ The first issue included a biographical essay on the life of Jason Lee by David Leslie, a poem by Margaret Jewett Bailey (also the author of Oregon's first book-length work of fiction, The Grains, or Passages in the Life of Ruth Rover), and an historical essay titled "The Fall of Empires." In the same issue, William G. T'Vault called for readers to submit writings for publication, and future issues of the Spectator show that many readers complied with T'Vault's request. ${ }^{8}$

The Oregon Spectator provided an early opportunity for local writers to publish their fiction and historical writings, and if it had sustained its growth it is possible that the OPA could have developed into a publishing operation that focused on regional literature. In fact, the Spectator was actually classified as a literary magazine for the U.S. Census of

\footnotetext{
${ }^{6}$ Ibid.

${ }^{7}$ George S. Turnbull, History of Oregon Newspapers (Portland, OR: Binfords \& Mort, 1939), 25. Turnbull provides a thorough examination of the Spectator, as does Himes in "History of the Press of Oregon."

${ }^{8}$ See Alfred Powers, History of Oregon Literature (Portland, OR: Binfords \& Mort, 1935) for reprints of poetry from the Spectator.
} 
1850. ${ }^{9}$ Newspaper operations were required to identify themselves as literary, neutral, political, religious, or scientific for the Census. The Spectator identified itself as literary, which is illustrative about how the OPA saw itself after four years of publishing. Perhaps because of its ambitious publishing schedule and size of the publication, the Spectator lasted only nine years, and for part of this time, during the California gold rush, its staff was absent and publication was erratic. The paper also experienced problems maintaining an editor because of clashes with the OPA over editorial content. ${ }^{10}$

Although it ceased operations in 1855, the Spectator had a distinct impact on the publishing economy by introducing readers to both news and local literature and fostering new literary markets. As the first major paper in the territory, it established distribution networks for printing supplies and publications that subsequent publishers would utilize. The Spectator's parent corporation, the OPA, experimented with the publication of books, and its failure provided future publishers with some important lessons about book pricing and distribution. ${ }^{11}$

As the Spectator faced editorial problems and eventual failure, the Weekly Oregonian, which would become the longest continually operating newspaper in the state, was established on December 4, 1850. Like the Spectator, the first issue of the Oregonian shows how local fiction was readily available and could be used to fill in gaps in newspapers when necessary. In a rush to get the first issue of the Oregonian printed

\footnotetext{
${ }^{9}$ United States Census Office. Statistical View of the United States ... Being a Compendium of the Seventh Census to Which are Added the Results of Every Previous Census, Beginning with 1790... (Washington: A.O.P. Nicholson, 1854), 154-157.

${ }^{10}$ Himes, "History of the Press of Oregon," 347-48.

${ }^{11}$ The Oregon Printing Association published: George Abernethy, Message of the Governor of Oregon Territory (Oregon City: Oregon Printing Association, 1846); The Oregon Almanac (Oregon City: Spectator Office, 1847); and Noah Webster, Abridged Edition of Our Elementary Spelling Book: Being an Improvement on the American Spelling Book (Oregon City: Oregon Printing Association, 1847).
} 
before local readers decided to subscribe to the newly founded Milwaukee Western Star (a Democratic party affiliated paper), the paper's editor, Thomas Dryer, filled the entire six columns of the front page with two fiction stories..$^{12}$ Both stories were anonymous; the first was titled "The Trapper: A Legend of the West," and the second was "The Fashionable Church." The placement of these pieces on the front page is noteworthy. One might expect to find filler on the fourth page of the paper, but to place it front and center indicates that editor felt the fiction would catch the readers' attention.

Despite steady growth in subscriptions, the Oregonian was struggling financially when Thomas Dryer sold the paper to Henry Pittock in $1860 .{ }^{13}$ One reason for these struggles was the emergence of numerous competitors encouraged by improved access to printing supplies. By 1856 paper mills had been established in the San Francisco Bay area, changing the entire cost structure for printing. ${ }^{14}$ Prior to the founding of West Coast paper mills, paper had to be imported by ship or overland from the East coast. By 1860 Portland was the home of three bookstores, including the Franklin store that distributed books and papers from all over the United States. ${ }^{15}$ Portland was also the home to four other newspapers including the Portland Daily and Weekly Times.

By January of 1861, Henry Pittock, who had worked as a printer for Thomas Dryer, had completely taken over operations of the Oregonian and was able to capitalize

\footnotetext{
${ }^{12}$ Robert C. Notson, Making the Day Begin: A Story of the Oregonian (Portland, OR: Oregonian Publishing Co., 1976), 6.

${ }^{13}$ Harvey W. Scott, History of the Oregon Country (Cambridge, MA: Riverside Press, 1924), 5:93.

${ }^{14}$ W. Claude Adams, History of Papermaking in the Pacific Northwest (Portland, OR: Binfords \& Mort, 1951), 2.

${ }^{15}$ Portland's three bookstores were: S.J. McCormick; J. L. Parrish \& Co.; and Charles Barrett, Sr. See advertisements in the Oregonian for 1860.
} 
on improved transcontinental transportation and advances in communications. ${ }^{16}$ By 1862 he was able to fill his paper with news about the American Civil War. In doing so, Pittock introduced the people of Oregon to the idea of reading a daily paper specifically for its news. The Oregonian was exceptional in its war news reporting. Although there was no direct trans-continental telegraph to Portland, Pittock made an arrangement to receive early telegraphic reports about the war by employing a series of couriers that delivered information exclusively from Yreka, California. ${ }^{17}$ Telegraph lines were finally completed from Yreka to Portland near the end of the Civil War in February of $1864 .{ }^{18}$

The transition of the Oregonian from a newspaper combining political discourse, literary contributions, and local news to a paper focused on national and local news marked the diversification of Oregon's publishing industry. This shift was made possible by the expansion of paper manufacturing on the west coast of North America. Paper costs continued to drop with the opening of paper mills in Oregon. In 1866, the Pioneer Paper Manufacturing Company was opened in Oregon City, and in 1868 Henry Pittock's Clackamas Paper Manufacturing Company opened a second mill at Park Place on the Willamette. ${ }^{19}$ It is possible that the Oregonian's financial success, as well as the success of other Oregon printers, was a result of Pittock's role as founder and owner of multiple paper mills in the Pacific Northwest. Notable among these mills was the Columbia River Paper Company opened at Camas, Washington, in $1883 .{ }^{20}$ This mill, which also included

\footnotetext{
${ }^{16}$ Turnbull, History of Oregon Newspapers, 110.

${ }^{17}$ History of the Oregonian (Portland, OR: The Oregonian, 1947), unpaginated pamphlet.

${ }^{18}$ Jeff W. Hayes, Tales of the Sierras (Portland, OR: F.W. Baltes, 1900), 74; and C. H. Chapman, "Western Personalities: The Oregonian Himself," Sunset: The Pacific Monthly 28 (1912): 597; and Scott, History of the Oregon Country, 3:187.

${ }^{19}$ Adams, History of Papermaking in the Pacific Northwest, 65.

${ }^{20}$ Ibid., 8.
} 
publisher and bookseller J.K. Gill as an investor and vice-president, featured the Pacific coast's first groundwood pulp mill and produced the region's first paper suitable for use in books.

The post-Civil War period was also marked by the rapid expansion of a transnational rail network and the growth of other more efficient transportation networks. The end result of the expansion of paper production and transportation networks was lower costs moving supplies like paper, ink, and finished printed goods. This resulted in lower costs for printing.

While newspapers provided printers with a stable income, Oregon printers were increasingly finding a secondary source of income through private printing jobs. The region's first printer, the Oregon Printing Association, which owned the Oregon Spectator, also utilized their press to print territorial government documents, broadside notices for private companies, almanacs, sermons, and school primers. The Oregonian also contracted with local organizations to print a variety of ephemeral items including organizational minutes and by-laws. ${ }^{21}$ Like newspaper printing, job printing did not require a serious investment on the part of the printer. As a result, it was common practice for newspaper publishers to use their press for job printing to supplement their income. During this period, authors like Cincinnatus H. Miller (later known as Joaquin Miller) began to pay printers for the printing of their own works. ${ }^{22}$ By the end of the

\footnotetext{
${ }^{21}$ See bibliographic entries 23, 36-40, 42, 48, 50, 51, 55, 60-62, 68, 72, 74, 77, 78, 97 134, 139, 145, 150, 230, 247, 298, 488, 498, 603, 671, and 734 in George Belknap, Oregon Imprints, 1845-1870 (Eugene, OR: University of Oregon, 1968).

${ }^{22}$ Miller paid for the printing of his first two books: Specimens (Portland, OR: George Himes, 1868) and Joaquin, Et Al. (Portland, OR: S.J. McCormick, 1869).
} 
1860s, Oregon had at least two bookbinders in addition to at least ten printers, providing potential authors with a variety of options for printing their own work. ${ }^{23}$

The costs involved in binding and distribution had been prohibitive for early Oregon printers. In 1847 the Oregon Printing Association made its first attempt at printing, binding, and distributing a book, an experiment that would end in financial disaster. The Abridged Edition of the Elementary Spelling Book by Noah Webster was printed on 95 pages, eleven by seventeen centimeters, much larger than the cheap Territorial Government pamphlets that would have been issued by the OPA. On November 16, 1846, the OPA printer reported to the OPA Board of Directors that the publication would cost an estimated $\$ 175$ for one thousand copies, a price that included thirty-four dollars for new equipment (presumably for stitching and binding) and an additional 1,000 copies for $\$ 62.50 .{ }^{24}$ The actual cost for printing was $\$ 235$, a bit less than the estimate. This cost did not include the charge of 12.5 cents per copy for hard binding, which the OPA paid to one of its printers, W.P. Hudson and a recent immigrant, Carlos Shane, who had learned binding in Ohio. Although the OPA only bound 720 copies, this was a significant cost. The unbound pages were sold for 25 cents. Therefore binding would have cost about fifty percent of the initial printing cost. Hard bound copies were initially offered for sale at 37.5 cents a copy, but in an effort to recoup cost, the prices were raised to fifty cents a copy in the course of a few months. Obviously binding costs were substantial, but distribution was equally problematic. The books were advertised in

\footnotetext{
${ }^{23}$ Figures on printers and binders were compiled from the Portland Directory for 1869: Embracing a Business and General Directory of Residents and a Directory of East Portland. Together with Other Statistical Information (Portland, OR: A.G. Walling, 1869).

${ }^{24}$ Oregon Printing Association Records, MSS. 950, Oregon Historical Society; Belknap, Oregon Imprints, 32 .
} 
the Spectator and sold in Oregon City stores, but the Oregon market could not absorb the full print run. Eventually two hundred fifty bound copies were sent to California for sale. Although it is impossible to say how many copies of the primer were sold in the end, surviving records show that less than 470 copies had been sold by the end of 1847 . After the publication of the primer, the OPA did not issue a single publication that required binding and distribution.

In 1852, the Oregonian printing office experimented with publication by printing Treason, Stratagems, and Spoils, a political satire of corruption within Oregon's Democratic Party, written in verse by William Lysander Adams. ${ }^{25}$ This is generally considered the first "literary" work to be published as a book in the Oregon Territory. A close look at the circumstances of this publication, however, shows that there was little risk involved in the publication of Treason, Stratagems, and Spoils. The work was originally published in serial form in The Oregonian. ${ }^{26}$ Thomas Dryer would have been well aware of the popularity of the work through reader responses to its serial publication. In re-issuing the work as a book, Dryer did everything possible to save on printing costs. The work was crowded into thirty-two pages, two columns per page, and was issued in cheap paper wraps. ${ }^{27}$ The book was sold directly through inquiries to the Oregonian and through the post-office. ${ }^{28}$

\footnotetext{
${ }^{25}$ David Alan Johnson, Founding the Far West: California, Oregon, and Nevada, 1840-1890 (Berkeley, CA: University of California Press, 1992), 55-6.

${ }^{26}$ William Lysander Adams, "Treason, Stratagems, and Spoils," Oregonian, February 14, 21, and March 6 and 13, 1852.

${ }^{27}$ Belknap, Oregon Imprints, 49, item 55. "Paper wraps" is the bibliographic term for glued, stitched, and stapled paperback bindings.

${ }^{28}$ Powers, History of Oregon Literature, 205.
} 
Simultaneous to the publication of Treason, the Oregon territory saw the establishment of its first legitimate publisher, Stephen J. McCormick. McCormick first established the Franklin Book Store as a distribution center for imported publications. ${ }^{29}$ With this part of his business in place, McCormick sought to develop a market for literature in the most cost-effective way possible. To this end, he acquired basic printing equipment and founded Oregon's first magazine, the Oregon [Monthly] Magazine in 1852, a work which attempted to capitalize on a developing market for literature in the Oregon territory, and according to Oregon literary scholar Alfred Powers, featured poetry and essays all by McCormick. ${ }^{30}$ A review of the magazine in the Salem Oregon Statesman complimented the production values of the magazine, but made no mention of the magazine's content. ${ }^{31}$

After establishing a readership and means of distribution, McCormick began work on his first book publication. His first step was the solicitation of A Comprehensive, Explanatory, Correct Pronouncing Dictionary, and Jargon Vocabulary by the Pacific Northwest Catholic priest, Francis Norbert Blanchet. McCormick was a practicing Catholic and close friend of Blanchet's, which made acquisition of the manuscript easy. ${ }^{32}$ This Chinook dictionary proved to be an astute choice for McCormick. During his twenty-seven years in Portland, McCormick published at least eleven editions of the work before selling the copyright to J. K. Gill, who published ten more editions between

\footnotetext{
${ }^{29}$ Ibid., 715.

${ }^{30}$ There appear to be no surviving copies of Oregon [Monthly] Magazine. In History of Oregon Literature, 714 , Powers states that the magazine was first issued in January of 1852, but he gives no information about the magazine's longevity.

31 Ibid.

${ }^{32}$ Gleanings of Fifty Years: The Sisters of the Holy Names in the Northwest, 1859-1909 (Portland, OR: Glass \& Prudhomme, 1909), 72.
} 
1881 and 1933. Surviving copies show that McCormick was thrifty in his decision to issue the work in wraps, saving the cost of hard binding and making the work more affordable in the modest and unproven Portland marketplace.

Over the next ten years, McCormick acted as the primary publisher and bookseller in the Oregon Territory. In 1854 he initiated an annual series of almanacs for Oregon and Washington, and in 1855 he issued the Franklin Advertiser, a semi-weekly magazine, which provided book reviews and information of the stock of McCormick's shop. In 1863 McCormick made another astute business decision and began the publication of a series of Portland city directories, which provided names, addresses, and professions of the city's citizens.

McCormick's almanacs, dictionaries, and directories were big sellers. According to Portland's Democratic Standard, the first installment of McCormick's almanac sold 5,000 copies. ${ }^{33}$ Perhaps this success made McCormick willing to gamble on fictional works that most job printers shied away from. In 1859, McCormick funded the publication of Captain Gray's Company by Abigail Duniway. ${ }^{34}$ Although the book was small in format (11 x 18 centimeters), McCormick did spend money on blind-stamped cloth bindings. ${ }^{35}$ Information about the number of copies that were sold is sketchy, but a notice in the Oregon Argus indicates that a print run of one thousand copies were stitched

\footnotetext{
33 [Portland] Democratic Standard, October 5, 1855.

${ }^{34}$ In History of Oregon Literature, Powers claims that most of the stock of Captain Gray's Company was destroyed in a fire. Oregon Imprints investigated this issue extensively and found no evidence to support this story. It is possible that the first print run of Duniway's later book, Path Breaking: An Autobiographical History of the Equal Suffrage Movement in Pacific Coast States (Portland, OR: James, Kerns \& Abbott, 1914), was destroyed in a fire. Copies of this book are all marked as "2nd edition," but the Oregonian does not feature any notices of a fire at the James, Kerns \& Abbott printing firm.

${ }^{35}$ A blind-stamp is an uncolored, impressed (de-bossed) mark or decoration on the binding of a book.
} 
and bound in smaller lots as dictated by demand. ${ }^{36}$ After a lapse of ten years, McCormick again tested the market for fiction with the publication of Joaquin Miller's second book of poetry, Joaquin, Et Al. (1869). Five hundred copies of this small book of poetry were printed and bound, but the publication can hardly have been considered a risk for McCormick. ${ }^{37}$ A year earlier, Joaquin Miller had financed the printing of his first book, Specimens (1868), with Portland printer George Himes as the printer. McCormick sold copies of the book in his Franklin Book Store, and there is no doubt that he saw the publication of a second Miller volume as a worthy investment. ${ }^{38}$

By the time McCormick left Portland for San Francisco in 1881 to become the editor of the Monitor, he had made great strides in developing a viable economic model for the publication of local literature through his bookstore, magazines, and sporadic publication of local literature..$^{39}$ Despite this progress, the publishing community remained small, and the local job printers were still dominated by the handful of firms that were established with the region's first newspapers.

One of these printing firms was the frequently renamed firm run by William D. Carter. Carter started his career in Oregon with the Milwaukee Western Star, first issued on November $21,1850 .{ }^{40}$ Early in 1851 Carter bought out Lot Whitcomb, the founder of the Western Star, and relocated the paper to Portland, where he changed the name of the newspaper to the Oregon Weekly Times. Shortly after setting up shop in Portland, the cash-strapped Carter sold the paper to his editor John Waterman. By 1854 Carter's

\footnotetext{
${ }^{36}$ Belknap, Oregon Imprints, 110.

${ }^{37}$ Ibid., 253; Powers, History of Oregon Literature, 235.

${ }^{38}$ Belknap, Oregon Imprints, 228.

${ }^{39}$ In Memoriam [Stephen James McCormick] (San Francisco, CA: 1891).

${ }^{40}$ Turnbull, History of Oregon Newspapers, 52.
} 
finances had improved and, in partnership with Russell D. Austin, he bought back the company. ${ }^{41}$ In buying back the company it appears that Carter had hopes of diversifying and printing books. Evidence of this new business model can be seen in Carter \& Austin's publication of a book within months of taking control of the press. The book was Margaret Jewett Bailey's The Grains, or, Passages in the Life of Ruth Rover, a work of historical fiction and poetic verse loosely based on Bailey's experiences living at the Willamette Mission. Bailey's writings had previously appeared in the Oregon City Spectator, and by the time The Grains was issued, she was a known figure in the Oregon territory. ${ }^{42}$ Although the book created a "great sensation" in the Oregon country, the economics of publishing made it difficult for Carter and Austin to profit on its publication. ${ }^{43}$ Carter and Austin economized by printing in two columns and issuing the work in paper wraps. They also advertised the book and took subscriptions as a way to gauge demand prior to printing. ${ }^{44}$ Without a storefront and distribution network like McCormick's, Carter and Austin had a difficult time selling Bailey's book, a matter made worse by the negative reviews of the book in local newspapers. ${ }^{45}$ Carter $\&$ Austin never again attempted such an ambitious project, but stuck to job printing of organizational bylaws, proceedings, and meeting minutes. In 1859 Carter sold his interest in the operation to Austin in order to focus on a new publishing partnership with another Portland printer, A.G. Walling. ${ }^{46}$

\footnotetext{
${ }^{41}$ Ibid., 53.

${ }^{42}$ Evelyn Leasher and Robert J. Frank, eds., The Grains or Passages in the Life of Ruth Rover... (Corvallis, OR: Oregon State University Press, 1985), 10.

${ }^{43}$ Obituary, "Margaret J. Crane [Margaret J. Bailey]," Puget Sound Weekly Courier, May 19, 1882.

${ }^{44}$ Oregonian, July 8, 1854.

45 Oregonian, August 5, 1854; and Oregonian, September 9, 1854.

46 Turnbull, History of Oregon Newspapers, 53.
} 
Carter's partnership with Walling appears to have been based on a shared ambition to be on the cutting edge of printing technology. Walling arrived in Oregon in 1850 as an ambitious twenty-two year old printer and initially found employment with the Oregonian ${ }^{47}$ Walling advanced quickly by utilizing his extensive knowledge of agriculture to write an agricultural science column that ran from 1854 through 1857 . The column ceased in December of 1857, and in August of 1858, Walling and Carter teamed up to issue the Oregon Farmer ${ }^{48}$ In 1859 , Walling joined a group of civic leaders in founding the Multnomah County Agricultural Society and the Oregon State Agriculture Society, which coincidentally helped the sales of Walling's paper. ${ }^{49}$ Carter and Walling worked together until they sold the paper to Henry Pittock in 1863. During this time period, Walling and Carter established a thriving job printing business, which used the most up-to-date engraving practices. For a short time they held the contract of printing the Portland City directories for McCormick under Walling's name. Walling continued to run a successful printing business after the two split.

With proceeds from the sale of the Oregon Farmer, Carter struck out on his own in 1864, and named his firm Carter's Job Office. ${ }^{50}$ Focusing on job printing, Carter achieved a fair measure of success. Oregon Imprints lists twenty-three titles printed by Carter between 1864 and 1870. Carter's eventual success as a job printer showed that by

\footnotetext{
${ }^{47}$ Powers, History of Oregon Literature, 738.

${ }^{48}$ Oregonian, December 29, 1897, p. 8.

${ }^{49}$ George H. Himes, "History of Organization of Oregon State Agricultural Society" Oregon Historical Quarterly 8 (1907): 317-328; and J.R. Cardwell, "The First Fruits of the Land: A Brief History of Early Horticulture in Oregon" Oregon Historical Quarterly 7 (1906): 31, 158-159.

${ }^{50}$ Oregonian, December 29, 1897, p. 8.
} 
the 1860s Portland could support multiple job printers that could operate without the support of newspaper or magazine publication as an additional revenue stream.

In 1866 Carter hired a young printer, George Himes, as a typesetter and printer. Himes purchased half of the company in 1867 , and by 1870 he was the sole owner of the firm, which became "George H. Himes, The Printer." ${ }^{51}$ Carter's sale of his business was the end of his career as a printer. He remained in Portland until his death in 1897. Himes continued the legacy of Carter's company through to the year 1900, when he retired from printing to serve as secretary for the newly founded Oregon Historical Society. According to Alfred Powers, during the nineteenth century, Himes "issued more books and separate publications than any other person or establishment in Oregon." ${ }^{52}$

By the end of William Carter's career as a printer in 1870, the market for print in Portland had grown to a point that allowed for specialization in all facets of the industry. Further proof of this market growth was the success of Leopold Samuel's elaborately illustrated West Shore magazine, which began publication in 1875, and remained in print for sixteen years. While the printers and publishers mentioned up to this point helped to shape public expectations for print, their contributions were gradual and muted. The West Shore, however, implemented technology for illustration on par with those in New York, Boston, and Philadelphia. These innovative illustrations enticed customers and introduced a large readership to the first large-scale publication of local creative writings and historical essays by Oregon authors, including Joaquin Miller, Belle Cooke, Samuel Simpson, George Himes, William Lysander Adams, Lindsay Applegate, and Frances

\footnotetext{
${ }^{51}$ Minnie Roof Dee, From Oxcart to Airplane: A Biography of George H. Himes (Portland, OR: Binfords \& Mort, 1939), 82-89.

${ }^{52}$ Powers, History of Oregon Literature, 738.
} 
Fuller Victor. The end result was that the West Shore helped feed an appetite for local material by forging connections between regional authors, readers, and the printed image of the Pacific Northwest.

Leopold Samuel was a German immigrant, who came to the United States as a twelve year-old boy in $1859 .{ }^{53}$ After two years of learning English and selling newspapers, Samuel left New York for San Francisco where he worked distributing hotel flyers, menus, and magazines in the goldfields. In 1871 Samuel moved again, this time to Portland, where he entered the publishing industry by printing and distributing travel guides and directories for the region. ${ }^{54}$

The ease with which Samuel entered the publishing industry in Portland, and then transitioned to publishing the first fully illustrated monthly literary magazine on the West coast, indicates just how much Portland had developed by 1875 . Unlike his publishing predecessors, Samuel had the advantage of developed shipping and transportation routes that provided him inexpensive supplies and access to a much more extensive regional, and even national market. The magazine was distributed to land offices and the Oregon Board of Immigration Commission, which had offices across the United States, and in Europe, New Zealand, and Canada ${ }^{55}$ Letters published in West Shore showed that regional postal networks helped ensure that the magazine received distribution in remote Oregon communities like Harrisburg, Ashland, and Jacksonville. Samuel made sure that these distribution networks operated to his advantage, advertising in West Shore: "We

\footnotetext{
${ }^{53}$ J. D. Cleaver, "L. Samuel and the West Shore: Images of a Changing Pacific Northwest," Oregon Historical Quarterly 94 (1993): 167.

${ }^{54}$ Interview with L. Samuel in Fred Lockley, History of the Columbia River Valley from The Dalles to the Sea, vol. 2 (Chicago, 1928), 916-18.

${ }^{55}$ Cleaver, "L. Samuel and the West Shore," 171.
} 
want a good local agent at every post office in Oregon and Washington Territory. We pay a liberal commission . .."56 By 1877 West Shore had built up circulation figures that exceeded all west coast publications except for the San Francisco dailies. ${ }^{57}$ What was most remarkable about this success was that the major content of the magazine, particularly in its formative years, was provided by Pacific Northwest authors.

Although successful in the beginning, Samuel suffered the same fate as other early Portland publishers. When Samuel's modern illustration techniques became available to more publishers, he was forced to enlarge, expand, and find increasingly expensive ways to make his magazine stand out. Under pressure from a new board of directors and criticism over his pro-immigration stance, Samuel left the magazine in 1891, and it ceased publication three months later. ${ }^{58}$ Despite its ultimate failure, Samuel's success promoting local authors bode well for the next generation of publishers. In fact, Samuel's business model was sound enough that one of his employees, William Bittle "pacific monthly" Wells implemented it with a new magazine, the Pacific Monthly, in 1898.

As an insider with West Shore, Wells believed that regional literature and politics had a large enough audience to support a magazine without the elaborate and expensive illustrations that were the calling card of West Shore. Wells' business model for Pacific Monthly reflected the continued expansion of the local literary community, as well as the growth of a reading market interested in local writings. Wells' first matter of business

\footnotetext{
${ }^{56}$ West Shore, January 1877, 217.

${ }^{57}$ S. M. Pettengill, Pettengill's Newspaper Directory and Advertisers' Hand-book for 1878 (New York, 1878), 196.

${ }^{58}$ Cleaver, "L. Samuel and the West Shore," 216.
} 
was to acquire the short-lived literary magazine Drift, which had put out a single issue under the editorial direction of Joaquin Miller's sister-in-law, Lischen M. Miller. ${ }^{59}$ Miller became an editor for the Pacific Monthly, and immediately called on her connections established through Drift to form a group of regular contributors that included Charles Erskine Scott Wood, Jack London, Joaquin Miller, Sara (Ergot) Bard Field, John Gill, and Frances Fuller Victor. ${ }^{60}$ After eight years as publisher, Wells sold Pacific Monthly to Portland's first banker, William S. Ladd in $1906 .{ }^{61}$ Ladd continued the operation of the magazine until 1912, when he sold it to Sunset Magazine, which gradually phased out its literary content.

Writing in 1952, after Binfords \& Mort had successfully sold hundreds of books by Oregon authors, many who had been published in the pages of Pacific Monthly, Wells wrote, "The most essential thing about Pacific Monthly is the influence it had on the development of the literature of the West." ${ }^{62}$ In economic terms, the Pacific Monthly served as an indicator of the strength of both the pool of writers and strength of the market for regional literature in the Pacific Northwest.

Additional signs that the publishing economy in Portland was primed for an explosion of regional publishing at the beginning of the twentieth century can be seen in the career of the job printer F.W. Baltes. Baltes arrived on the printing scene in Portland in 1888 just as the West Shore was beginning to flounder. Born in Ilwaco, Washington, in 1860, Baltes received training in printing in Astoria before relocating to Portland. Baltes

\footnotetext{
${ }^{59}$ The Pacific Monthly, October 1898, 35.

${ }^{60}$ Powers, History of Oregon Literature, 720.

${ }^{61}$ William Bittle Wells Papers, AX 95, University of Oregon, Box 9. This account of the Pacific Monthly is taken in large part from Wells's unpublished autobiography.

${ }^{62}$ William Bittle Wells Papers, Box 9, Folder 3, letter to Gerald Rasmussen, April 19, 1954.
} 
was probably the first printer in Portland to treat his business scientifically. He developed a reputation for never making mistakes in estimating prices, a reputation which was further enhanced with the publication of his own book on the subject titled, The Cost of Printing: A System in Practical Operation, with Forms and Books Especially Adapted to Large and Small Printing Concerns (1894). ${ }^{63}$

As a job printer, Baltes dominated the Portland market, particularly after the retirement of George Himes. He printed yearbooks for colleges and high schools throughout the Pacific Northwest, in addition to creating advertisement materials, business forms, and stationary for insurance companies, dental firms, furniture companies, The Oregonian, the Portland Chamber of Commerce, and the Oregon Historical Society. One correspondent wrote to Baltes with praise in 1935 that he must have had "every important printing contract in the city." 64

Perhaps the most interesting aspect of Baltes's business was the large number of poetry broadsides and fictional writings that he printed for local authors. It should be noted that Baltes was never a publisher, and did not finance or distribute any of these publications. Rather, authors came to him, and paid him to print their works. Baltes printed works for numerous Portland writers, and aspiring writers including: T.C. McCready, Helen Starret, Harvey Scott, Charles Erskine Scott Wood, Jeff Hays, Charlotte Parker, and Theodore Eckerson, to name a few. Charles Erskine Scott Wood's publications, including Maia (1918) and Sonnets (1918) in particular, are exemplary in their production values.

${ }^{63}$ Frank William Baltes Papers, MSS. 1592, Oregon Historical Society, Box 1. ${ }^{64}$ Ibid. 
Baltes's business in vanity printing (self-publication) is interesting for a number of reasons. First, it shows that there were still only a few viable outlets for aspiring writers in late nineteenth/early twentieth century Portland. The Pacific Monthly remained the main local publication that actively sought out regional authors. Baltes's success also showed that authors were willing to spend their own money on publications, lending credence to the assertion that over the previous fifty years the Pacific Northwest had developed a sense of appreciation and value for local writing. Before entering the publishing business, the Binfords were job printers, and through observing the success of vanity press books, they became aware of the market for regional literature. It is also worth noting that Baltes was recognized for his use of high quality papers, which by the 1880s had plummeted in cost, making it even more affordable for authors to fund the printing of their own books. Baltes printed up until his death in 1932, two years after Peter and Maurice Binford started Portland's first regional publishing firm.

Two other job printers of significance in Portland during the end of the nineteenth century and through the 1920s were Mann \& Beach and Glass \& Prudhomme. Both of these printers issued books for private clients in the absence of a local publisher, showing that there was substantial demand for a local publisher. Mann \& Beach was in business during the Lewis and Clark Centennial and American Pacific Exposition and Oriental Fair of 1905. During that time they issued numerous Exposition related publications, including those of the Sacajawea Statue Association. ${ }^{65}$ They also issued Dr. OwensAdair: Some of Her Life Experiences (1906), one of the most important early

\footnotetext{
${ }^{65}$ From a survey of Glass \& Prudhomme publications listed in the WorldCat First Search database, http://firstsearch.oclc.org.
} 
autobiographies written by an Oregon woman. Glass \& Prudhomme was a more substantial printing business that also produced books for private clients including Lydia Taylor's From Under the Lid (1913), an exposé on prostitution in Portland; E.T. Allen's The Ambitious Tree: A Story for Western Children (1912); Alfred Rice's An Oregon Girl: A Tale of American Life in the New West (1914); and Charles Botsford's Poems (1911).

The final piece of the economic landscape of publishing in Oregon was the development of adequate retail outlets for books. Stephen J. McCormick had laid the foundation for bookselling with his Franklin Book Store in 1852. Numerous small stationers and booksellers followed, but the watershed moment for bookselling was the opening of the J.K. Gill bookstore. In 1870 Joseph Kendall Gill, in partnership George Steel, opened what would become a Pacific Northwest icon. J.K. Gill served as a retail store for books, a publisher, a stationer, and a distributor for smaller publishers. ${ }^{66} \mathrm{~A}$ shrewd businessman, Gill, like Pittock at the Oregonian, invested in paper mills and went to great lengths to establish expansive distribution networks. The end result was a lower production cost for the books sold by J.K. Gill, as well as a greater market. In 1922 Gill expanded its operations to include the sale of office furniture, architectural supplies, engraving services, records, music, and leather goods. ${ }^{67}$ Gill's book endorsements became crucial to the success of locally published and written books. At the height of the regional publishing movement around 1950, J.K. Gill was described as "one of the largest retail and wholesale concerns of its kind on the Pacific Coast." ${ }^{68}$ Gill's function in relation to

\footnotetext{
${ }^{66}$ Howard McKinley Corning, Dictionary of Oregon History (Portland, OR: Binfords \& Mort, 1956), 99.

${ }^{67}$ Oregonian, August 22, 1943, p. 15.

${ }^{68}$ Corning, Dictionary of Oregon History, 99; Oregonian, October 2, 1931, p. 1; Portland Journal, October 2, 1931, p. 1 .
} 
regional publishers was particularly important because it provided publishers like Caxton (Idaho), Binfords \& Mort, and Superior (Seattle) with a stable and guaranteed market and a buffer to the risk previous publishers had to take on with distribution. J.K. Gill continued to expand and merge with national interests until 1980 when the firm was purchased by the Bro-Dart library supply company, ending its original function as a bookstore. ${ }^{69}$

The true measure of the health of the bookselling business in Portland cannot be measured solely by J.K. Gill's success. By 1892, there were twenty-five booksellers in the city of Portland, an increase from the five shops in the city just ten years earlier. ${ }^{70}$ Once again, further expansion of the paper industry helped both booksellers and a new crop of printers like the Binfords. In 1905 the Crown Paper Company of West Oregon City and the Columbia River Paper Company in Camas, Washington, were merged and purchased by investors in San Francisco, who went on to merge the Oregon mills with the Floriston Paper Company of California in 1911. From 1911 to 1928, the Crown Paper Company continued to purchase more mills in Oregon and California, and also began acquiring timberlands and water rights to support their operations. ${ }^{71}$ In 1928 Crown merged with another paper giant, the Zellerbach Corporation of San Francisco, to form Crown Zellerbach, a giant corporation with assets of one hundred million dollars, a manufacturing capacity of 1,450 tons of paper per day, and timber holdings of 350,000

\footnotetext{
${ }^{69}$ Oregonian, August 19, 1980, p. A11.

${ }^{70}$ Information taken from the Portland City Directory for the years 1863 to 1892.

${ }^{71}$ Adams, The History of Paper Making in the Pacific Northwest, 18-20.
} 
acres. ${ }^{72}$ At the time of its merger, Crown Zellerbach was the second largest paper manufacturer in the United States. ${ }^{73}$ It is debatable as to whether the consolidation of the paper industry was a long-term benefit for the publishing industry, but there is little doubt that the efficiencies, the timber holdings, and the increased capital for modernization allowed Crown Zellerbach to produce massive amounts of paper that had to be sold at a competitive price. Portland's location on the Columbia and Willamette rivers allowed printers access to locally produced papers without paying high transportation costs. It is no coincidence that many of Metropolitan Press's first books used Zellerbach paper. ${ }^{74}$

The development of the economy for publishing in Oregon was a gradual process. First newspaper publishers, who operated on small budgets and capitalized on advertising revenue, developed distribution networks for their publication, cultivated a readership base, established trade networks for the importation of supplies, and helped develop a pre-existing base of writers with an interest in writing about the region. With basic distribution networks in place, some newspaper publishers experimented with both job printing and book publication. Book publication proved to be an expensive and risky project for newspapers, as seen in the failure of the Oregon Spectator's attempt to publish a school textbook. The first successful book publisher in the territory, Stephen J. McCormick, established a book-selling business, which lessened the risk of carrying expensive book stock. Despite the moderate successes in book publishing exhibited by McCormick and Carter \& Austin, the Oregon market proved to be too small. As a result,

\footnotetext{
${ }^{72}$ From the chronology for The Lehman Brothers Collection at Harvard University, http://www.library.hbs.edu/hc/lehman/chrono.html?company=crown_zellerbach_corp.

73 Ibid.

${ }^{74}$ Based on an examination of colophons for Metropolitan Press books from 1931 to 1933.
} 
magazine publication, which did not require the expenses associated with book production and benefited from advertising revenue, became a popular medium for the publication of regional literature and history. Magazines like West Shore capitalized on developed transportation and distribution networks, but avoided the extra costs of binding associated with book publication. With the popularization of local magazine authors like Joaquin Miller and C.E.S. Wood, the interest of books by regional authors began to grow. Job printers like F.W. Baltes and Metropolitan Press were sought out by local authors who paid them to print their books. The authors then handled the sales and distribution of their own books, and even without the distribution networks available to a regular publisher, they were able to successfully sell their books. With a larger population and the presence of booksellers like J.K. Gill, this vanity publication business became a viable financial endeavor, and by the beginning of the twentieth century it was clear that economic conditions in Oregon were right for the establishment of regional book publishers. 


\section{READERS AND WRITERS IN OREGON}

Economic factors influenced the development of a thriving book publishing industry in Oregon. The specific character of these publishing programs was determined by a number of cultural factors. As a frontier outpost, the Oregon territory became the home of numerous educated and literate individuals including missionaries, military officers, and scientists. Many of these individuals were enthusiastic writers and supporters of cultural initiatives, whose endeavors helped create public interest in regional history and literature. In addition, national cultural movements like the arts and crafts movement, literary societies, the professionalization of higher education, and regionalism all influenced Oregon writers, who, in turn, shaped Oregon's publishing industry.

Oregon's first settlers were not primarily motivated by making a quick profit like those in other areas of the west. The first wave of immigrants was made up of missionaries who began arriving in the Oregon Territory in the 1830s. The printed word was important to this group, and in 1839 the $\mathrm{ABCFM}$ sent a press to its mission at Lapwai, Idaho. These missionaries believed that their religious teachings would be more effective if they were communicated in native languages. In 1838 the mission resolved that "we apply ourselves to the study of the Native Language \& reduce it to writing."." The Mission Press issued at least a dozen titles over the next eight years, including primers and bibles in Flathead, Spokane, Cayuse, and Nez Perce languages. ${ }^{2}$

\footnotetext{
${ }^{1}$ Howard Ballou, "The History of the Oregon Mission Press," Quarterly of the Oregon Historical Society 23 (1922): 39.

${ }^{2}$ George Himes, "History of the Press of Oregon 1839-1850," The Quarterly of the Oregon Historical Society 3 (1902): 330; WorldCat FirstSearch, http://firstsearch.oclc.org; and Wilfred Schoenberg, Jesuit
} 
Missionaries had an impact on the literary culture of the Pacific Northwest beyond the Nez Perce texts issued by the Mission Press. The first novel published in the Oregon territory, The Grains, or Passages in the Life of Ruth Rover was written by a member of the Willamette Valley Methodist mission, Margaret Jewett Bailey, in 1854. Bailey also penned poems for the Oregon Spectator. Edwin Bingham, a scholar of Pacific Northwest literature, describes Bailey as one feminist determined "not to be cowed in a male-dominated frontier community."33 Although a controversial figure during her lifetime, Bailey was the first of many Oregonians to turn explore religion and society through literature.

The first attempt at a complete history of Oregon was also penned by a missionary, Dr. William H. Gray. Gray arrived in Oregon in 1836 with the Whitman mission, and relocated to the Willamette Valley in $1838 .{ }^{4}$ Despite its strong moral overtones, the book became one of the early standard histories of the state of Oregon. The work was originally planned to be printed in Portland; a prospectus for the work was issued by George Himes in 1867 and in 1869, but the 624 page folio-sized work proved too much of a financial risk for Himes. ${ }^{5}$ By 1870 , Gray agreed to allow the risk of the publication to be shared by three companies. Harris \& Holman of Portland handled local distribution of the book; H.H. Bancroft \& Company of San Francisco was responsible for

Mission Presses in the Pacific Northwest: A History and Bibliography of Imprints, 1876-1899 (Portland, OR: Champoeg Press, 1957).

${ }^{3}$ Margaret Jewett Bailey, The Grains and Passages in the Life of Ruth Rover, eds. Evelyn Leasher and Robert J. Frank (Corvallis, OR: Oregon State University Press, 1986), v.

${ }^{4}$ Howard McKinley Corning, Dictionary of Oregon History (Portland, OR: Binfords \& Mort, 1956), 103.

${ }^{5}$ George Belknap, Oregon Imprints, 1845-1870 (Eugene, OR: University of Oregon, 1968), 252. 
the printing and wider western distribution of the book; and the American News

Company of New York distributed the book east of the Mississippi. ${ }^{6}$

Although not a part of the early missions, Thomas Condon, who arrived in

Oregon in 1853, was an ordained congregational minister who followed in the literate tradition of the missions. Condon moved among a number of Oregon communities and churches until he arrived at the Dalles, where he found an ideal location to combine his interest in geology and theology. ${ }^{7}$ From the Dalles, Condon became aware of the John Day Fossil beds, which became the primary research material for his geologic history of Oregon, The Two Islands, published by J.K. Gill in 1902.

Whether through religious texts, fiction, science, or history, Oregon missionaries were interested in both writing and reading. The text-based focus of the missionary communities would be passed on to future generations of Oregon's population, laying the foundation for the future emergence of widespread amateur authorship in the Oregon. The literature in nineteenth century Oregon would have been far less developed without the contributions of missionaries and clergy. Their motivation to seek and share knowledge through writing was the starting point for the growth of regional literature.

The second group that had a significant impact on the development of literary culture in Oregon were the U.S. Army officers sent to the Pacific Northwest to maintain

\footnotetext{
${ }^{6}$ Hubert Howe Bancroft founded the Bancroft publishing company in San Francisco in 1852. In 1868 he shifted his focus to writing and transferred management of the company to his brother Albert Little Bancroft, and it became known as the A. L. Bancroft Company. Although regional in nature during its early years, the Bancroft publishing venture rapidly expanded its scope. H. H. Bancroft's never saw California as an isolated region, but rather the center of a much larger connected Pacific empire. For more information see: John Walton Caughey, Hubert Howe Bancroft: Historian of the West (Berkeley, CA: University of California Press, 1946); and Harry Clark, A Venture in History: The Production, Publication, and Sale of the Works of Hubert Howe Bancroft (Berkeley, CA: University of California Press, 1973).

${ }^{7}$ Alfred Powers, History of Oregon Literature (Portland, OR: Binfords \& Mort, 1935), 111.
} 
order between settlers and Native Americans. Many of the officers who chose to remain in the region beyond their service were highly educated and held enlightened views about the treatment of Indians and other social issues of the time. Regardless of whether the men were scientists or poets, they wrote and were instrumental in establishing a literary culture. The main source of educated soldiers was West Point, which had a reputation for providing the best training among institutions of higher learning for scientific studies like engineering, mathematics, and medicine. ${ }^{8}$

Among the officers who settled in the Oregon Territory, one of the most prominent was Dr. Rodney Glisan. Glisan graduated from the Medical School at the University of Maryland in $1849 .{ }^{9}$ Rather than practicing medicine, Glisan opted for a military medical career by gaining an appointment as an officer with the U.S. Army. During the 1850s, Glisan was stationed at various locations on the Great Plains, and in 1855 was ordered to report to Fort Orford on the Southern Oregon coast. ${ }^{10}$ While in Oregon, Glisan witnessed the Rogue River Indian Wars and the removal of the Rogue Indians from their ancestral lands to the Grand Ronde reservation in the northwest part of the state. In 1861, Glisan left the army, settled in Portland, and began a medical career. ${ }^{11}$

Glisan had a stellar reputation as a doctor, but it was his curiosity and skill as a writer that made him particularly interesting. Throughout his time in the military, Glisan

\footnotetext{
${ }^{8}$ Discussions of the Army and science in the American West can be found in: A. Hunter Dupree, Science in the Federal Government (Cambridge: Harvard University Press, 1957); James P. Ronda, Beyond Lewis \& Clark: The Army Explores the West (Tacoma: Washington State Historical Society, 2003); and Bonnie Hardwick, "Science and Art: The Travel Writings of the Great Surveys of the American West after the Civil War" (PhD diss., University of Pennsylvania, 1977).

${ }^{9}$ Corning, Dictionary of Oregon History, 100; Olaf Larsell, "The Development of Medical Education in the Pacific Northwest," Oregon Historical Quarterly 27 (1926): 66; Joseph Gaston, Portland Oregon: Its History and Builders (Portland: S.J. Clarke, 1911), 206-09.

${ }^{10}$ Rodney Glisan, Journal of Army Life (San Francisco: A. L. Bancroft, 1874), 205.

${ }^{11}$ Gaston, Portland Oregon, 206-209.
} 
kept a meticulous journal, which he published as Journal of Army Life with A.L. Bancroft of San Francisco in 1874. In the sections of the book relating to Oregon, Glisan provided a history of the Indian wars, as well as one of the only detailed descriptions of the lifeways of the Tututni Indians written before their removal to the Grand Ronde and Siletz reservations. ${ }^{12}$ Glisan's discussions of the culpability of settlers in the Oregon territory in the conflicts with the Indians was unusual for the period. In addition to Journal of Army Life, Glisan published two other books: Textbook of Modern Midwifery (1881) and Two Years in Europe (1883).

As the husband of Elizabeth Couch, daughter of one of Portland's founders, and the city's pre-eminent physician, there is no doubt that many Portlanders would have read Glisan's books. Given the prominence of Glisan and his writings in Portland, one can assume that he influenced others to keep journals, write, and most likely take an interest in the history of the Pacific Northwest prior to European settlement.

Two officers that never achieved the elevated social status of Glisan were August V. Kautz and Benjamin Alvord. Stationed primarily at Ft. Steilacoom in Washington, Kautz became the first American to survey and climb Mt. Rainier. ${ }^{13}$ Kautz was an active writer, who kept a careful journal in which he recorded Native American customs and observations on the natural and social history of the Pacific Northwest. His account of climbing Mt. Rainier and history of the region was published in the Overland Monthly in

\footnotetext{
12 Jeremy Skinner, "The United States Army and the Development of Science, 1848-1861" (BA thesis, Lewis \& Clark College, 1999).

${ }^{13}$ Fred Beckey, Range of Glaciers: The Exploration and Survey of the Northern Cascade Range (Portland: Oregon Historical Society), 298-302.
} 
1875. ${ }^{14}$ Benjamin Alvord, a West Point graduate, also took the opportunity while serving in Oregon during the Indian Wars to write and publish his observations on a variety of topics. While commander of Fort Dalles, Alvord published a number of mathematical treatises and at least one historical/sociological piece about the native Wasco-Wishram Indians for Harpers Magazine. ${ }^{15}$ Neither Alvord nor Kautz ever received the regional attention given to Rodney Glisan, but their efforts provide further evidence of the high levels of education introduced to the Pacific Northwest through the military presence.

Three other soldiers, who were read throughout Oregon, were Major Theodore J. Eckerson, Henry H. Woodward, and Charles Erskine Scott Wood. Not coincidentally, all three published works of poetry, a genre that enjoyed great popularity in the United States during the nineteenth century. Major Theodore J. Eckerson was stationed in the Oregon territory from 1838 to $1865 .{ }^{16}$ After retiring from the military and settling in Portland, Eckerson began writing poetry. In 1881 Eckerson's book, When My Ship Comes In, and Other Rhymes of Camp and Hearth, was published by the Riverside Press in Cambridge, Massachusetts. The book sold out within ten years and Eckerson commissioned F.W. Baltes in Portland to print a second edition. According to Eckerson's introduction to the work, many friends urged him to print the work, which may explain how he was able to fund printing the work by Baltes. There are no surviving records on how well the second printing sold, but he seems to have gained a certain amount of local

\footnotetext{
${ }^{14}$ August V. Kautz, “Ascent of Mount Rainier,” Overland Monthly 14 (1875): 393-403.

15 Benjamin Alvord, “The Doctor-Killing Oregons," Harpers New Monthly Magazine 68 (1884): 364-65.

${ }^{16}$ Francis B. Heitman, Historical Register of the United States Army: From its Organization September 29, 1789, to September 29, 1889 (Washington D.C.: National Tribune, 1890), 249.
} 
notoriety. In 1903 one of his poems, "Oregon," was deposited in the cornerstone of the Lewis and Clark monument at Forest Park. ${ }^{17}$

Like Eckerson, Henry H. Woodward was a military officer who spent his retirement writing poetry. From his southern Oregon home in Roseburg, Woodward wrote The Pioneer's Offering (1867) and Lyrics of the Umpqua (1889). ${ }^{18}$ Woodward funded the printing of The Pioneer's Offering, a sixteen-page pamphlet. Despite what George Belknap describes as the "poor" quality of his poetry, Woodward found a New York publisher for Lyrics of the Umpqua. ${ }^{19}$ In 1875 he found a London publisher for a collection of his works titled Select Poems. George Belknap, the author of Oregon Imprints, speculates that Woodward's success beyond Oregon was a result of publishers being eager to capitalize on his potential to be an international sensation from the wilds of Oregon like Joaquin Miller. ${ }^{20}$ Ultimately, Woodward's readership was primarily local in nature. His poems about the Rogue Indian Wars, the Umpqua River, and the geology of Douglas County were key contributions to the growing body of Oregon literature. ${ }^{21}$

The most influential Oregon military poet was Charles Erskine Scott Wood. In 1875 he arrived as an officer stationed at Fort Vancouver. Highlights of Wood's military career included participating in the 1877 Taylor Expedition to Alaska, serving as General Howard's aide-de-camp during the U.S. Army's war with the Nez Perce Indians, and

\footnotetext{
${ }^{17}$ Powers, History of Oregon Literature, 465.

${ }^{18}$ A Century of Oregon Poetry: From the Private Collection of Brian Booth (Portland, OR: Friends of the Aubrey Watzek Library, Lewis \& Clark College, 2004), 11; The Henry H. Woodward Papers, 1885-1905, MSS. 873, Oregon Historical Society.

${ }^{19}$ Belknap, Oregon Imprints, 220.

${ }^{20}$ Ibid.

${ }^{21}$ Henry H. Woodward, Lyrics of the Umpqua (New York, NY: John B. Alden, 1889) and The Pioneer's Offering (Roseburg, OR: Ensign Printing, 1867).
} 
translating Chief Joseph's famous surrender speech. ${ }^{22}$ In 1884 Wood left the Army and opened a successful law practice in Portland, which allowed him to focus on writing and his patronage of the arts. Wood's contributions to the literary and artistic community went far beyond that of his military contemporaries. Wood utilized his connections to New York to introduce Portland to a number of popular artists, including the New York sculptor Olin Warner, who was commissioned to design the Skidmore fountain, as well as a bronze sculpture of Chief Joseph. Wood sponsored the residency of New York impressionist Childe Hassam at the Portland Art Museum, and served as director of the Library Association of Portland, where he led a fundraising campaign that resulted in the construction of the library's first owned building. ${ }^{23}$ Wood was also instrumental in founding the Portland Art Museum and arranging purchases and gifts for the museum's permanent collection. ${ }^{24}$ As a writer, Wood was a regular contributor to, as well as editor and shareholder of the Pacific Monthly. ${ }^{25} \mathrm{He}$ also self-published in Portland a number of works of poetry, including Poet in the Desert (1915), which was issued in multiple printings, including a mass market edition by the Vanguard Press of New York in 1929. It is difficult to measure precisely the overall influence of Wood on Oregon literature, but it is possible to get a general sense by looking at his involvement with Pacific Monthly. Wood was the journal's most frequent contributor. From 1904 to 1911

\footnotetext{
${ }^{22}$ General information on Wood's life was gathered from Robert Hamburger, Two Rooms: The Life of Charles Erskine Scott Wood (Lincoln, NE: University of Nebraska Press, 1998); Erskine Wood, Life of Charles Erskine Scott Wood (Vancouver, WA: Rose Wind Press, 1991); Edwin Bingham and Tim Barnes, eds., Wood Works: The Life and Writings of Charles Erskine Scott Wood (Corvallis, OR: Oregon State University Press, 1997); George Venn, Soldier to Advocate: C.E.S. Wood's 1877 Legacy: A Soldier's Unpublished Diary, Drawings, Poetry, and letters of Alaska and the Nez Perce Conflict (La Grande, OR: Wordcraft of Oregon, 2006).

${ }^{23}$ Hamburger, Two Rooms, 88.

24 Ibid.

${ }^{25}$ Bingham and Barnes, eds., Wood Works, 19.
} 
he published in the journal as least 136 times. ${ }^{26}$ As editor of Pacific Monthly Wood worked hard to support the publication of poetry. ${ }^{27}$ The magazine published an average of twenty-four poets a year, and the poetry served as models for amateur local poets like Ada Hastings Hedges, a future author and editor for the Binfords \& Mort publishing company, who modeled a series of poems about the Oregon desert after Wood's own poetry. ${ }^{28}$ This new generation of Oregon poets and readers of poetry were a key part of the market on which Binfords \& Mort would capitalize in coming years.

Without Wood's writings and his support of Portland's printing community, the local literary scene might have remained stagnant. In a letter to Wood's son Erskine, Harry Corbett summarized Wood's contribution, writing, "the whole of Portland as it once was owes much of its culture to him ... There are few who can shape the trend of thought of a whole city. Certainly he did that for this town and just as certainly that same extraordinary influence of his moved into the most unexpected places." ${ }^{29}$

The military presence in Oregon boosted the percentage of authors in the region and helped support the literary growth in Oregon communities. The writings of this population group were clearly attempts to describe a new environment in the manner George Venn described in "Continuity in Northwest Literature." ${ }^{30}$ The best of these attempts would serve as models for the regional literature that would be published by Binfords \& Mort well into the twentieth century. Despite the perception of this type of

\footnotetext{
${ }^{26}$ Ibid., 105.

${ }^{27}$ Ibid.

${ }^{28}$ In his Oregon Encyclopedia (www.oregonencyclopedia.org) entry for "Ada Hastings Hedges," Ulrich Hardt claims that Hedges worked as an assistant editor for Binfords \& Mort and describes the relationship between Hedges' and Wood's poetry.

${ }^{29}$ Harry Corbett to Erskine Wood, n.d. [photocopy], Charles Erskine Scott Wood Papers, box 125, folder 2, Huntington Library, San Marino, CA.

${ }^{30}$ Bingham and Love, eds. Northwest Perspectives, 99-118.
} 
writing as antiquated, its popularity lasted far beyond the appearance of more modern writings, like those of H. L. Davis.

Beyond the local impact of individual writers, there was a much larger cultural change taking place throughout the United States that had a significant influence on Oregon's literary marketplace at the beginning of the twentieth century. This change was the increasing demand for books from the middle class. This demand was a part of a much larger American phenomenon. In Why the American Century? Olivier Zunz described the ways in which corporations scientifically manipulated the culture of American consumption during this period. According to Zunz, corporate officials came to the realization that consumers required money to buy products, which prompted companies like Ford to gradually increase wages, allowing a wider population to have an expendable income, and leading to greater demand for manufactured products. ${ }^{31}$ Higher wages paired with aggressive advertising that employed scientific studies designed to identify the needs and attitudes of the "average" American resulted in growth in sales for all kinds of products, including books. Entire publications like Ladies Home Journal and Good Housekeeping became vehicles for promoting lifestyles of consumption. ${ }^{32}$

The effect of consumer culture on the publishing industry was magnified further by the movement for educational improvement, which demanded that new demographic groups read and own books. As a result, publishers created entire sets of books like the Harvard Classics and Dr. Eliot's Five-Foot Shelf of Books that were available at affordable prices and meant to be read by the average American. Public figures like Vice

\footnotetext{
${ }^{31}$ Olivier Zunz, Why the American Century? (Chicago, IL: University of Chicago Press, 1998), 81.

${ }^{32}$ Megan Benton, Beauty and the Book: Fine Editions and Cultural Distinction in America (New Haven, CT: Yale University Press, 2000), 14.
} 
President Calvin Coolidge implored the general populace to read, and in the process equated books with success. Coolidge wrote:

Do you want a mind that is keen, straight-thinking, well balanced? Then you must read books. Do you want to be efficient, up-to-date, successful in your work? Then you must read books. Do you want to develop the spiritual side of you sympathy, imagination, love? Then you must read books. . . you must do more than read them. You must own them, make them part of you. And you must choose the right books. ${ }^{33}$

Despite the public outcry about the importance of reading, many people had no real interest in reading. Most were content to simply demonstrate to their peers that they owned the books that were expected of someone of intelligence and means. A sarcastic editorial written by Thomas Masson in the Independent, a Harper's literary magazine from 1923, illustrated the extent to which the public would attempt to use books to appear intellectual; the editorial also showed the contempt held for this behavior by social elites. Masson wrote that it was possible to exhibit one's intelligence by grouping . . .

a few high brow books at a strategic point, so that as the guest enters his eye will fall upon them at once. ... Anyone entering and seeing these flowers of literature carelessly disposed on a near-mahogany table just inside of the living-room bounds, would say to himself at once: "Here we have culture! Here we have literary delicacy!" ... Thus, with the judicious expenditure of a few hundred dollars, you can erect an intellectual entanglement that will keep you quite safe in your domestic trenches. ${ }^{34}$

One of the most popular writers of the period, Emily Post, took the notion of maintaining social appearances with books to an even more superficial level, instructing her readers on how to re-cover books that did not match their home decor. ${ }^{35}$

\footnotetext{
${ }^{33}$ Calvin Coolidge, "Books for Better Homes," The Delineator 103 (August 1923): 2.

${ }^{34}$ Thomas L. Masson, "Domestic Bookaflage," Independent, April, 14 1923, 256.

${ }^{35}$ Benton, Beauty and the Book, 19.
} 
Closely related to a greater social emphasis on reading was the emergence of women's literary clubs in the wake of the Civil War. ${ }^{36}$ Women's groups that had organized to promote the abolition of slavery evolved into social organizations focused on reading and social advocacy. The sociologist Elizabeth Long claims that these literary associations involved thousands of women from across the United States. The demand for books created by these associations resulted in a rapid expansion of the book trade in frontier regions. ${ }^{37}$ In Oregon, various women's clubs that placed an emphasis on literacy, education, and self-improvement were founded in Pendleton, LaGrande, and Portland. The Portland Woman's Club founded in 1896 formed a special library committee with the sole purpose of promoting the adoption of legislation that would allow taxation for local libraries, which proved to be a benefit to readers and the publishing industry ${ }^{38}$ By 1900, the Portland Woman's Club offered its members the opportunity to study German, Oregon history, parliamentary law, Shakespeare, the home, French, ancient poetry, modern poetry, and the writings of Robert Browning. ${ }^{39}$ Based on this list one can see the demand for books generated through the women's clubs, and in Portland there was clearly a specific interest in and demand for books about the history of Oregon.

While consumerism, literacy, and women's groups fostered book sales among new readers, the book buying habits of well-educated and wealthy readers also began to

\footnotetext{
${ }^{36}$ Elizabeth Long, "Aflame with Culture: Reading and the Social Mission in the Nineteenth-Century White Women's Literary Club Movement," in Print in Motion: The Expansion of Publishing and Reading in the United States, 1880-1940, eds. Carl F. Kaestle and Janice Radway (Chapel Hill, NC: University of North Carolina Press, 2009), 480.

${ }^{37}$ Long, "Aflame with Culture," 480-81.

${ }^{38}$ Works Progress Association, History of the Portland Woman's Club (Portland, OR?: n.d.); and Oregon Federation of Woman's Clubs, Fifty Years of Progress, 1899-1950 (Portland, OR: 1950).

${ }^{39}$ Sandra Haarsager, Organized Womanhood: Cultural Politics in the Pacific Northwest 1840-1920 (Norman, OK: University of Oklahoma Press, 1997), 137-8; and 1901-2 Yearbook, Portland Woman's Club Records, 1895-1995, Mss. 1084, Oregon Historical Society, Portland, OR.
} 
change. The popular embrace of the book bred a market for expensive, limited edition volumes among the social elite looking to distinguish themselves from the middle classes.

The search for social distinction through books was memorialized in what is arguably the quintessential book of the 1920s, F. Scott Fitzgerald's Great Gatsby. At one of Gatsby's elaborate parties, a guest expressed his admiration for the fact that Gatsby's books are "bona-fide piece[s] of printed matter," an illusion of intelligence which was perceived as intended by the self-conscious cultural pretender Jay Gatsby. ${ }^{40}$

As Lawrence W. Levine points out in Highbrow Lowbrow: The Emergence of Cultural Hierarchy in America, this process of differentiation was not limited to book purchasing habits. Levine describes other cultural institutions such as the theater, opera, and art museums as the means by which high culture differentiated itself from popular culture. In the publishing world, the motivations of upwardly mobile socialites like Gatsby were critical to the success of the fine press movement.

By the 1920s, printers and artists reacted against what they perceived to be the deleterious effects of industrial publishing and began to raise the standards for book production. The new books known as fine press editions were distinct in form from the standard trade books of the period. They could be easily identified by their handmade paper, carefully selected handset type, superior artistic design with original illustrations, and their sturdy bindings. Fine press books began to be printed in America during the early years of the twentieth century, and saw an explosion of popularity in the 1920s.

${ }^{40}$ F. Scott Fitzgerald, The Great Gatsby (New York: Scribner's, 1925), 55. 
The most visible and acknowledged English influence on the American fine press movement was the Kelmscott Press, the most influential of a group of English presses that applied pre-industrial printing techniques to their work. William Morris, director and designer at the Kelmscott Press, was revered by American fine printers for his stunning medieval-style printing. ${ }^{41}$ In 1891 he founded the Kelmscott Press, where Morris printed on handmade paper and vellum, designed his own typefaces, and used a hand press that was a direct descendant of the one first employed by Johann Gutenberg. Rather than seeking to publish the writings of cultural icons, Morris issued editions that fit his preference for medieval design such as Chaucer and Beowulf. The Kelmscott Press printed their books in extremely small editions, usually selling out its print runs before the books had even come off the press. This saved the press from having to extensively publicize or pay for distribution. Later American book designers regularly attempted to mimic Morris's style. It is almost impossible to overstate Morris's influence on the American fine press movement. ${ }^{42}$

The two seemingly contradictory strains of the English fine press tradition were the elaborately produced, expensive, for-profit publications that targeted class-conscious elites, and books that were designed as a return to artistic hand-made publications. Though seemingly at odds, the two traditions were crucial to the development of the American fine press movement. The exploitation of class-consciousness would allow the movement to survive in an exclusively capitalist economy, while the artistic focus

\footnotetext{
${ }^{41}$ Morris is better known as a print designer and key figure in the Arts and Crafts movement. ${ }^{42}$ Susan Otis Thompson, American Book Design and William Morris (New Castle, DE: Oak Knoll Press, 1996); William S. Peterson, The Kelmscott Press: A History of William Morris's Typographical Adventure, (Berkeley and Los Angeles: University of California Press, 1991).
} 
allowed the creation of a product that could not be mass-produced for a large middleclass, thus creating its own exclusivity through production methods.

In Portland during the first quarter of the twenty-first century, the first signs of the fine press movement were seen with the elaborate book and broadside designs of F.W. Baltes for C.E.S. Wood. Throughout his life, Wood was interested in hand printing. When his son Maxwell was young, Wood helped Maxwell and his friend, Lewis A. McArthur, establish a printing press in the family attic, which printed a small newspaper called "The Bee" and a collection of Pacific Northwest Indian stories assembled by C.E.S. Wood titled Book of Tales. ${ }^{43}$ According to Wood scholar Edwin Bingham, Wood envisioned a production in the style of William Morris for Book of Tales (1901). He purchased special type in New York and hand-made paper in Holland. It is not clear whether or not the boys bound the 105 printed copies themselves, but in the end, half of the books were bound in morocco leather and half in vellum. ${ }^{44}$ Wood was caught up in the fine press movement, and desired to have more of his works printed in an artistic manner. In 1904 Wood submitted a manuscript to Walter M. Hill, a bookseller from Chicago, who commissioned the Elston Press of New Rochelle, New York, one of the early American fine press printers, to print A Masque of Love (1904). ${ }^{45}$ Wood's fine presswork lapsed over the next eight years as he focused on writing for the Pacific Monthly, but in 1912 he began a close relationship with the Portland printer, F.W. Baltes.

${ }^{43}$ Erskine Wood, Life of Charles Erskine Scott Wood (Vancouver, WA: Rose Wind Press, 1991), 102; and Charles Erskine Scott Wood, A Book of Tales: Being Some Myths of the North American Indians (Portland, OR: McArthur \& Wood at the Attic Press, 1901).

${ }^{44}$ Bingham and Barnes, eds., Wood Works, 87.

${ }^{45}$ Throughout his career as bookseller, Walter M. Hill commissioned the publication of numerous fine press books. In addition to the Elston Press, Hill worked with John Henry Nash and the Torch Press. For a thorough overview of this early period of American fine press printing, see Will Ransom, Private Presses and Their Books (New York, NY: R. R. Bowker, 1929). 
Among the Baltes publications for Wood were a series of Christmas publications that Wood gave away as gifts. These included: The Legend of King Luke of Brittany (1912); The Beggar at the Gate (1913); and A Christmas Cantata (1915). Wood also commissioned Baltes to print four major literary works: Circe (1919), The Poet in the Desert (1915); Sonnets (1918); and Maia (1918). Maia was the pinnacle of Baltes's fine presswork. The folio-sized book was printed on hand-made paper, each page blindstamped with a symbol that included Wood's date of birth and two dolphins under the setting sun. Presumably the dolphins represented Wood's genius by linking him with the famous printer's mark of Aldus Manutius. The book was illustrated with intricate engravings and bound in boards with a cloth spine standard for fine presswork of the time.

Although Oregon was not a center of fine presswork, Oregon's printers did find artisan print jobs with a handful of wealthy clients like Wood, Harvey Scott (editor of the Oregonian), Helen Ekin Starrett (suffrage leader and founder of Chicago's Starrett school for girls), and Charlotte Parker (socialite and wife of Portland banker Alfred F. Parker).

While the fine press movement affected the physical production of books in Oregon, the professionalization of American universities and academic societies had an impact on the types of books written by Oregon authors. ${ }^{46}$ As scientific research became integral to academic studies, it became necessary for scholars to share their findings with their colleagues and to maintain current knowledge of their subject. By the end of the

\footnotetext{
${ }^{46}$ Cecile M. Jagodzinski, "The University Press in North America: A Brief History," Journal of Scholarly Publishing 40 (2008): 1-20. See also: Arthur M. Cohen, The Shaping of American Higher Education: Emergence and Growth of the Contemporary System (San Francisco, CA: Jossey-Bass, 1998); Laurence R. Veysey, The Emergence of the American University (Chicago, IL: University of Chicago Press, 1970); and John Tebbel, A History of Book Publishing in the United States (New York, NY: R.R. Bowker, 1981).
} 
nineteenth century, university officials had concluded that the best way to facilitate this was through the publication of journals and monographs. The first universities to establish university presses were Johns Hopkins (1878), Chicago (1891), and the University of California at Berkeley (1893). ${ }^{47}$

In Oregon, university presses struggled to carry out the basic functions expected of modern university presses. The University of Oregon's first foray into publishing came in 1894, when it began to issue the Bulletin of the University of Oregon, which featured faculty writings. From 1894 to 1919 the University commissioned numerous college publications like yearbooks and academic catalogs, as well as a handful of faculty writings. In 1919 the University established a fund for the publication of academic monographs, a critical step in raising research standard for Ph.D. candidates, which formed the basis for a University press program ${ }^{48}$ From 1920 to 1930 the program expanded to include the publication of the Commonwealth Review, the Oregon Law Review, Oregon Exchanges (journalism), Extension Monitor, and the Old Oregon. While this group of publications was thought of as a publishing program by the University of Oregon, it never expanded to the point of publishing peer-reviewed monographs by scholars from outside of the University. The University of Oregon still issues a handful of scholarly journals, but lacks a fully functional university press.

While Oregon State University never claimed to have a university press until 1961, like the University of Oregon it sponsored the publication of a series of

\footnotetext{
${ }^{47}$ Contrary to popular belief, the prominent Ivy League schools like Yale and Harvard were quite late in establishing modern university presses dedicated to publishing the research of its faculty. Yale's press was established in 1908 and Harvard's in 1913.

${ }^{48}$ Henry D. Sheldon, History of the University of Oregon (Portland, OR: Binfords \& Mort, 1940), 204-6.
} 
monographs started in 1939 and continued until 1973. The series included studies in botany, economics, education, entomology, geology, history, literature, mathematics, and zoology. Almost all of the authors in this series were faculty at Oregon State. While the series served the vital function of getting the work of OSU faculty in print, the series failed to include the top research in its fields of emphasis, and it never gained widespread circulation. $^{49}$

The modest performance of Oregon's university presses was important to the early success of Binfords \& Mort. Scholars seeking to publish on topics relating to Oregon had limited options. Before 1939, Oregon State University was not an option. The University of Oregon was only interested in its own scholars, and that interest was limited in scope. The University of Washington began to issue books in 1915, but it maintained a focus on the state of Washington. Some scholars chose to publish their works at the University of California, but most turned to Binfords \& Mort. ${ }^{50}$ In addition to poetry and fiction written by scholars at Oregon universities, Binfords \& Mort became the foremost publisher of natural history works relating to Oregon. Works published by the firm between 1930 and 1939 included Birdwatching in the West (1931); Roadside Flowers of the Pacific Northwest (1932); Northwest Nature Trails, A Natural History of Oregon and Washington (1933); Ferns of the Northwest (1934); Wild Flowers of the

\footnotetext{
${ }^{49}$ Since 1961 the Oregon State University Press has established itself as the primary university press in the state of Oregon. They issue about fifteen titles per year with an emphasis on "the intellectual, cultural, and social development of Oregon and the West." Oregon State University Press website, http://oregonstate.edu/dept/press/.

${ }^{50}$ The University of California Press issued approximately 90 books about Oregon between 1930 and 1970 including works by John Galbraith, Philip Drucker, Sherburne Cook, and Clifford Drury.
} 
Pacific Coast (1934); Handbook of Northwest Flowering Plants (1936); Animals of the

Seashore (1936); Nature Rambles in the Wallowas (1937).

Like the universities, historical societies began to professionalize in the late nineteenth century. Societies that had traditionally been meeting places for social elites and antiquarians began to be centers for serious scholarly study. ${ }^{51}$ This movement was apparent in Madison, Wisconsin, where Reuben Gold Thwaites established a scholarly research and publication program, and brought the Wisconsin Historical Society to national prominence. Oregon attempted to implement the Wisconsin model. Historians and antiquarians agreed that it would be in everyone's best interest if the Oregon Pioneer Association, an organization founded in 1872 to memorialize the contributions of Oregon's white settlers, was re-organized as the Oregon Historical Society. The new society's mission statement, adopted in 1898, had a distinct focus on the publication of professional historical research. ${ }^{52}$

In its early years the Oregon Historical Society sponsored the publication of historical research through its magazine, Oregon Historical Quarterly. The magazine was instrumental in inspiring extensive historical projects. Since the society did not have the ability to publish books in its early years, the new surplus of historical writings created a printing and publishing market for printers like Binfords \& Mort. Historical publications were the bread and butter of Binfords \& Mort's publishing firm throughout its existence.

\footnotetext{
${ }^{51}$ Peter Novick, That Noble Dream: The "Objectivity Question” and the American Historical Profession (Cambridge, MA: Cambridge University Press, 1998); John Higham, et al. History (Englewood Cliffs, NJ: Prentice-Hall, 1965); Amanda Laugesen, "George Himes, F.G. Young, and the Early Years of the Oregon Historical Society” Oregon Historical Quarterly, 101 (2000): 18-39.

52 Proceedings of the Oregon Historical Society (1898-1899): 1-23; and Amanda Laugesen, "George Himes," 18-39; and Amanda Laugesen, "Making Western Pasts: Historical Societies of Kansas, Wisconsin and Oregon, 1870-1920" (PhD diss., Australian National University, 2000), 221-25.
} 
In the early twentieth century there was a desire among Oregonians to be modern in all aspects of society, including in their education system. ${ }^{53}$ Supporting a modern university publishing program, however, required extensive capital. Neither the Oregon university system nor the Oregon Historical Society could support comparable publishing programs. Binfords \& Mort, and to a certain degree other regional publishers, reaped the benefits of the inabilities of these organizations to publish.

A final cultural movement that influenced the ideas of Oregon writers and readers was regionalism. During the nineteenth century, historians, geographers, sociologists, and literary scholars began to question the role of the environment and local circumstances on the development of local history and culture. By the early twentieth century in the United States, these questions and concerns had moved beyond the academic community to form a tangible movement in the arts, which one scholar described as an "outpouring of regional novels, poems, and painting. ${ }^{, 54}$ In Oregon, this could be seen in numerous new books, both fiction and non-fiction, that drew on the pioneer experience and the geography of the region.

Regionalism had its roots in the professionalization of the study of history, which began in nineteenth century Germany. Some of the earliest historians to argue the influence of local environment on the development of human history were Leopold von Ranke (1795-1886), who applied his ideas to argue that the history and environment of

\footnotetext{
${ }^{53}$ One example of education rhetoric in Oregon is the following editorial: H. S. Lyman, "Teaching History: Paper Contributed by Professor H. S. Lyman, of Astoria, to Oregon Teachers' Monthly," Oregonian, November 24, 1901, p. 22.

${ }^{54}$ Michael Steiner, Region and Regionalism in the United States: A Source Book for the Humanities and Social Sciences (New York, NY: Garland Press, 1988), 334. For information about the history of regionalisms, see Merrill Jensen, ed., Regionalism in America (Madison, WI: University of Wisconsin Press, 1951); and Tom Lutz, Cosmopolitan Vistas: American Regionalism and Literary Value (Ithaca, NY: Cornell University Press, 2004).
} 
Prussia made it a unique situation, and Achille Loria, who proposed the idea of economic sociology, in which local environmental circumstances dictate economic outcomes. ${ }^{55}$

These ideas about the influence of regions were a good fit in North America, where from its very beginnings the British had governed colonies as a clearly defined group of regions. It was natural for historians to describe the United States as a group of regions.

One of the earliest and most significant American historians to apply these ideas to great effect was Frederick Jackson Turner (1861-1932). ${ }^{56}$ Throughout the nineteenth century, geographers like Samuel Morse and scientists like John Wesley Powell had experimented with different schemas and terminology to define the various regions of the United States. ${ }^{57}$ Turner attempted to incorporate these regional definitions into his historical analysis. Turner's 1893 frontier thesis argued that the success of the United States as a nation was the result of a uniquely "American" character. This character was forged in rugged wilderness of the West, and fostered individualism, democracy, and widespread opportunity for economic autonomy. Turner also argued that as the American West became settled, these American characteristics would gradually fade. ${ }^{58}$

\footnotetext{
${ }^{55}$ See Georg G. Iggers and James M. Powell, eds., Leopold von Ranke and the Shaping of the Historical Discipline (Syracuse, NY: Syracuse University Press, 1990); Leonard Krieger, Ranke: The Meaning of History (Chicago, IL: University of Chicago Press, 1977); Lee Benson, Turner \& Beard: American Historical Writing Reconsidered (New York, NY: The Free Press, 1965).

${ }^{56}$ Turner referenced Loria, and later in life acknowledged the influence of Loria's ideas on his thinking, Benson, Turner \& Beard, 21-34.

${ }^{57}$ See John W. Powell, "Physiographic Processes," in The Physiography of the United States (New York, NY: National Geographic Society, 1896); Jedediah Morse, The American Geography or, a View of the Present Situation of the United States of America (Elizabeth Town, NJ: Printed by Shepard Kollock, for the author, 1789); Fulmer Mood, "The Origin, Evolution, and Application of the Sectional Concept, 17501900" in Regionalism in America (Madison, WI: University of Wisconsin Press, 1951).

${ }^{58}$ Although Turner's ideas about the frontier were influential, they have been the subject of extensive criticism, including the argument that the idea of the frontier and free land ignores the realities of native peoples. See Ray Allen Billington, Frederick Jackson Turner: Historian, Scholar, Teacher (New York, NY: Oxford University Press, 1973); Frederick Jackson Turner, The Frontier in American History, with a Foreword by Ray Allen Billington (New York, NY: Holt, Rinehart and Winston, 1962).
} 
Regional publishing and regional literature followed the historical movement, and during the early years of the twentieth century experimental "advance guard" or "little magazines" emerged across the United States. ${ }^{59}$ These magazines rarely had large circulation and they were notorious for lasting for a just a few issues, but they were crucial in launching the writing careers of numerous authors.

Another important influence on regionalism were the policies of the federal government, which compiled census data based on region, and distributed federal funds by region. New Deal programs in particular, like the Tennessee Valley Authority, Bonneville Power Administration, and Works Projects Administration, imposed a regional structure on working class citizens, artists, and intellectuals.

Whether through the influence of academic trends or actions of the federal government, it was clear that artists, writers, and critics had adopted a strong appreciation for work with regional identity by the 1920s. Universities began establishing regional creative writing programs, and numerous influential literary magazines like the Saturday Review of Literature supported the movement. ${ }^{60}$ Prominent literary critics like H. L. Mencken began look for signs of regional dialect as an important aspect to quality literature. While this quality was evident in the popularity of writers like William Faulkner and John Steinbeck, it was also evident in some of the lesser-known Pacific Northwest authors like H. L. Davis. A review of Honey in the Horn published in The Saturday Review claimed, "Slow, unsmiling, mournful-voiced humor which seems to

\footnotetext{
${ }^{59}$ The most comprehensive treatment of advance guard literary magazines is Frederick J. Hoffman, et al., The Little Magazine: A History and Bibliography (Princeton, NJ: Princeton University Press, 1946).

${ }^{60}$ Vernon Carstenson, "The Development and Application of Regional-Sectional Concepts, 1900-1950" in Regionalism in America (Madison, WI: University of Wisconsin Press, 1951), 109.
} 
have come from our backwoods or our ranches - that is the spirit of this book, and for that, above all the other reasons, it deserves all the praise it is certain to receive as 'authentic Americana."”61

National acclaim for works about Oregon was not limited to Davis. Mencken also praised the scholarly compendium, Oregon Geographic Names (1928) as a "truly admirable work..." of "extraordinary resourcefulness. ${ }^{62 "}$ Numerous New York and Chicago publishing firms began producing book lists with large numbers of Pacific Northwestern books. In 1936 Macmillan of New York published Mansions in the Cascades by Anne Shannon Monroe and Elizabeth Lambert Wood, which although a fictional novel set in Oregon, argued that descendants of Oregon Trail pioneers were endowed with a "wildness" reminiscent of Turner's thesis. The idea that a novel such as Mansions in the Cascades could be marketed to a national audience shows the wide acceptance of regional literature in early twentieth century America. This interest in all things regional by readers across the United States, as well as intense local interest in regional literature, led to the emergence of strong regional publishing houses during the first four decades of the twentieth century.

Binfords \& Mort was not the only Pacific Northwest publisher to focus on regional publishing during the early years of the twentieth century. In Caldwell, Idaho, the Caxton Printers began printing regional literature in $1907 .{ }^{63}$ The Caxton Printers made

\footnotetext{
${ }^{61}$ The Saturday Review of Literature, May 9, 1936.

${ }^{62}$ H. L. Mencken, The American Language: An Inquiry into the Development of English in the United States: Supplement Two (New York, NY: Knopf, 1948), 550-51.

${ }^{63}$ Paul Emigh Johnston, A History of the Caxton Printers, Limited of Caldwell, Idaho (M.A. thesis, University California, Berkeley, 1956), 55-56; Leo W. York, The Caxton Printers Ltd. of Caldwell, Idaho: A Study in Regional Publishing (M.S. thesis, Florida State University, 1956); Wallace Stegner, "Decade of Regional Publishing: Caxton Printers of Caldwell, Idaho," Publishers' Weekly 135 (March 15, 1939):
} 
money through job printing and through its role as the textbook depository for the state of Idaho, which it used to print local fiction and poetry. ${ }^{64}$ James Gipson, the Caxton Printers' manager, felt that regional literature was important enough that he could ignore profitability for certain books as long as his business broke even. Gipson claimed, "Books are not accepted by us primarily because we think they will sell, but because they should, in our opinion, be published." ${ }^{65}$ Caxton's greatest success was their discovery of Vardis Fisher, whose books were bestsellers throughout the United States. ${ }^{66}$ Seattle's Superior Publishing Company also capitalized on interest in regional history and literature. From 1945 to 1983 , Superior specialized in large format illustrated works of regional history. ${ }^{67}$ In 1930, when Binfords \& Mort decided to start publishing books about the Oregon, the United States was mired in the Great Depression. Nonetheless, Peter and Maurice Binford confidently invested in the creation of books. To the Binfords, it was obvious that Oregonians had not only become literate and interested in reading, but that the cumulative impact of nineteenth century social movements had led Oregonians to crave books that told stories about the Pacific Northwest.

1060-1064; Vardis Fisher, The Caxton Printers in Idaho, A Short History (Cincinnati: Society of Bibliosophers, 1944).

${ }^{64}$ Johnston, A History, 14-15.

${ }^{65}$ Ibid., 3.

${ }^{66}$ Caxton Printers have operated continuously to the present using a business model similar to the one they developed in the early twentieth century.

${ }^{67}$ Ralph W. Andrews, "Pioneering Pictorial Histories: First Twenty-five Years of Superior Publishing Company," Journal of the West 11 (April, 1972): 367-78; Archie Satterfield, "Publisher Has Keen Interest in Northwest," The Seattle Times, September 8, 1968; Boyd Burchard, "40 Titles Later: Book House Proves Experts Wrong," The Seattle Times, March 5, 1961. 


\section{THE BINFORDS \& MORT PUBLISHING HOUSE}

Peter and Maurice Binford were experienced printers and businessmen when they started their publishing company in 1930. Their career began at a young age and was shaped by pioneer experiences they shared with many of the characters in the books they would publish.

On the tenth of January, 1879, a forty-five year old farmer by the name of Caleb Binford was buried in the Oak Hill Cemetery of Crawfordsville, Indiana. ${ }^{1}$ At the time of his death, Caleb's family included his wife Emily, two adult children, and nine children still living at home and ranging in age from two to nineteen years old. ${ }^{2}$ After Caleb's death, his wife Emily attempted to manage the sizable family farm and take care of the young children, but this task proved to be too much. Seven months after her husband's death, Emily was also dead. ${ }^{3}$ The eldest Binford child still living at home was nineteenyear-old Julia, who took on the responsibility for the household until 1884, when she and her husband Frank Lee relocated to Oregon with the two youngest boys, Peter and Maurice (pronounced Morris). ${ }^{4}$

The move placed the two Binford boys in a radically different environment, physically and culturally. Peter and Maurice had daily contact with Native Americans

\footnotetext{
${ }^{1}$ Find A Grave, "Caleb W. Binford," http://www.findagrave.com/cgibin/fg.cgi?page $=$ gr\&GRid $=21016360$.

${ }^{2}$ Courtland Matthews, "Binfords \& Mort: A Publishing Dream Come True," Sunday Oregonian, December 28, 1947, 3; and Genealogy.com, http://genforum.genealogy.com/scudder/messages/1062.html.

${ }^{3}$ Find A Grave, "Emily J. Binford," http://www.findagrave.com/cgi-bin/fg.cgi?page=gr\&GRid=21016382.

${ }^{4}$ Matthews, "Binfords \& Mort," 3; FamilySearch, https://www.familysearch.org/s/recordDetails/show?uri=http\%3A\%2F\%2Fpilot.familysearch.org\%2Frecor ds\%2Ftrk\%3A\%2Ffsrs\%2Frr_373818\%2Fp2\&hash=HloWXpZgU9zB10k5M56iYku8TUc\%253D; and Richard Mort, interview by author, July 2007.
} 
and even attended school at the Chemawa Indian school for a short time. ${ }^{5}$ Frank Lee was a well-read man who exposed the boys to literature and folklore throughout their childhood. ${ }^{6}$ A Binfords \& Mort company newsletter from 1950 described the impact of the Oregon landscape on the brothers saying, "This was the region they knew-the land of green hills, rugged mountains, giant forests, and mighty rivers where the pioneers had come to settle and found life good. .. . They [the Binfords] would publish books, books that would come out of this country that had so much to tell and was so big.""

When Frank and Julia Lee moved to Oregon in 1884, Frank found work teaching agricultural science at the government Indian school in Forest Grove. Shortly after Lee's arrival, the school closed, and the Lees moved to Chemawa Indian School near Salem. ${ }^{8}$ In 1887 the Lees relocated to High Prairie, Washington, in the Klickitat County Cascades, about halfway between Lyle and Goldendale. The Lees and the Binford children shared a house with Frank Lee's cousin until he was able to build a house, which, according to Nelia Binford-Fleming, was "frail and poorly built, with walls of a single thickness of boards." 9

After a few years of homesteading, Lee moved his family twenty miles east to Goldendale, Washington. Lee had purchased the Goldendale Tribune, thinking that printing would be a better fit for his interests than teaching or farming. ${ }^{10}$ Even as young

\footnotetext{
${ }^{5}$ Leona Ayres, “The History of Binfords and Mort, a Regional Publishing Company, in Portland, Oregon with Critical Annotations of Its Juvenile Books in Print in December, 1954" (MLS Thesis, University of Washington, 1955), 30.

${ }^{6}$ Richard Mort, interview by author, July 2007.

${ }^{7}$ Janet Binford, ed. Of Books \& Mortals: A Small Informal Magazine Issued Free and Occasionally. 1 (January-March 1950): 1.

${ }^{8}$ Matthews, "Binfords \& Mort," 3; and Ayres, "The History of Binfords and Mort," 30.

${ }^{9}$ Nelia Binford-Fleming, Sketches of Early High Prairie (Portland, OR: Binfords \& Mort, 1949), 35.

${ }^{10}$ Ayres, "The History of Binfords and Mort," 30.
} 
boys Peter and Maurice took an interest in the printing operation. The two worked for one year as printer's devils (formal apprentices) on the small weekly paper and shared duties including ink preparation and type setting. Although the boys only lived in Klickitat County for four years, the place left an indelible mark on them. There the boys developed a passion for regional lore and history, as well as for printing. Frederick Homer Balch, who later wrote Bridge of the Gods and was an early compiler of regional lore, lived in the vicinity of the Binfords and worked as a preacher in both Hood River and Klickitat County. There is little doubt the Binfords were acquainted with Balch, and developed a deep appreciation for him as the first chronicler of the Klickitat region. In later years, the Binfords acquired the copyright and republished Bridge of the Gods (1938). They also issued Balch's last unpublished work, Genevieve: A Tale of Oregon (1932). In addition to works by Balch, the Binfords published other important historical works about Klickitat County, including Robert Ballou's Klickitat Valley Days (1938), Clarence Orvel Bunnell's Legends of the Klickitats (1933), and Nelia Binford-Fleming's Sketches of Early High Prairie (1949).

In 1888 the Goldendale Tribune office was destroyed by a fire that burned the entire town. ${ }^{11}$ In the wake of the fire Frank Lee relocated his family to Portland, and purchased a weekly newspaper, the Northwest Pacific Farmer, previously owned by Joseph Gaston, who later was the author of a number of books about Portland and the surrounding area. ${ }^{12}$ After settling in Portland, the Binford brothers worked

\footnotetext{
${ }^{11}$ Paula Becker, "Fire Destroys Seven Blocks of Downtown Goldendale on May 13, 1888," HistoryLink, www.historylink.org; and Pete May, ed., History of Klickitat County (Goldendale, WA: Klickitat County Historical Society, 1982).

${ }^{12}$ Alfred Powers, History of Oregon Literature (Portland, OR: Binfords \& Mort, 1935), 566.
} 
apprenticeships at the Northwest Pacific Farmer. An annual subscription to the paper was just $\$ 1.00$, which meant marketing and selling advertisements was an important part of the business. ${ }^{13}$ The boys completed their apprenticeships and attained journeyman status in 1891. Pooling their earnings from the previous three years, the Binfords purchased a \$25 Excelsior Hand Platen Press and rented space in the Rookery building located on a pier overhanging the Willamette on Morrison Street. ${ }^{14}$

The Binfords' first imprint was a small monthly magazine issued in 1891 . The magazine was titled the Young American and bore the slogan, "Published by Boys for Boys and Girls." Peter and Maurice managed to assemble a subscription list of around one hundred readers, which allowed them to continue printing the magazine for eight years. While publishing the Young American, the Binfords also began to build a job printing business, which eventually occupied so much of their time that the brothers suspended publication of the Young American in 1899. It was clear that the Binfords had the skills and experience to make money as printers, but they did not have the equipment and financing to expand. With the aid of Frank Lee, the brothers purchased the Metropolitan Printing Company of Portland at a sheriff's auction in $1899 .{ }^{15}$ The Binfords kept the name Metropolitan Press and opened their print shop at Second and Morrison streets. In 1902 the Binfords relocated the business to 147 Front Street because of noise complaints from a neighbor, and in 1908 the firm moved again to 211 Oak Street. ${ }^{16}$

\footnotetext{
${ }^{13}$ Information taken from issues of The Northwest Pacific Farmer, December 11, 1902, December 18, 1902, and December 25, 1902.

${ }^{14}$ Matthews, "Binfords \& Mort," 3.

${ }^{15}$ Ibid.; and Ayres, "The History of Binfords and Mort," 30; and Irving Petite, "Binfords \& Mort Preserves Pacific Northwest's History," The Seattle Times, November 15, 1953.

${ }^{16}$ Matthews, "Binfords \& Mort," 3.
} 
During their initial ten years of job printing, the Binfords developed a customer base that stretched across the Pacific Northwest, including large corporations like the National Copper Mines Company and the Alaska Steamship Company. The majority of the firm's work consisted of ordinary print jobs like stationery, advertising materials for businesses such as the Multnomah Hotel, and corporate letterheads, but it also included a handful of books, including two works in 1909 and 1917 for the local Portland author, Marion Cook Stow.

The job printing business at the end of the nineteenth century was quite competitive. Maurice Binford, business manager for Metropolitan Press, attempted to protect the Metropolitan Press by joining an association of printers in the Pacific Northwest engaged in price fixing. In 1902 a large number of Portland's printers formed a group known as the Franklin Association, which included prominent printers such as F.W. Baltes, S.C. Beach, W.S. Duniway, and W.E. Prudhomme. ${ }^{17}$ At a 1904 banquet hosted by the Franklin Association, the printer Lee Clark described the goals of the association.

We as members of the Franklin Association should lay aside all personal differences. I feel that our organization has been a great benefit to all; the employer with a small plant reaping advantages as well as those maintaining more extensive establishments. ... I desire emphatically to assert that the Franklin Association is not a printing combine or trust. It is merely an aggregation of firms and individuals working along common lines in a common cause for the good of all. ... We do not desire to be unfair or to make unfair prices, but to produce work at a figure which will cover cost of production with a reasonable margin of profit. ${ }^{18}$

\footnotetext{
${ }^{17}$ Oregonian, February 24, 1904, p. 16.; and Ibid., October 21, 1906, p. 12.

${ }^{18}$ Ibid., February 24, 1904, p. 16.
} 
There is some truth to Clark's assertion that members were simply working for the greater good of all members. To assist members with budgeting and planning print jobs, one of the Franklin Association's leaders, F.W. Baltes, wrote and published, The Cost of Printing. Baltes claimed that by utilizing his forms and tables the printer could "conduct the business of a regular book and job printing establishment, show actual time of producing work, the cost of production and operating expenses, and furnish uniform and just prices." ${ }^{19}$ Another Franklin Association member, W.E. Prudhomme, provided guidance on graphic design in a twenty-page booklet titled Catalogues that Escape the Waste Basket (1912). ${ }^{20}$

While members benefited from the expertise of their peers, the Association was only marginally legal in the minds of many customers and unaffiliated printers. In 1907 the Oregonian reported on the practices of the Franklin Association in these terms:

Bitter complaint concerning the methods of the Franklin Association, which they say is one of the closest combines ever operated in the Pacific Northwest, is being made by owners of the few remaining independent printing establishments, who say regular trust methods are in vogue and that the Franklin Association, of which C.W. Hodson, State Senator, was president last year, is anything but legitimate. ${ }^{21}$

The Franklin Association functioned by establishing close ties to Pacific

Northwest paper companies. The Association negotiated exclusive contracts with these manufacturers and threatened to purchase paper elsewhere if the paper companies sold to printers that were not part of the Association. As a result, printers who were not members had to absorb the higher cost of importing paper.

\footnotetext{
${ }^{19}$ F. W. Baltes, The Cost of Printing (Portland, OR: F. W. Baltes and Company, 1894).

${ }^{20}$ Glass \& Prudhomme, Catalogues that Escape the Waste Basket (Portland, OR: Glass \& Prudhomme, ca. 1912).

${ }^{21}$ Oregonian, February 8, 1907, p. 10.
} 
Customers seeking a print job who asked for a bid from any Association member were told that a bid would be ready the next day. Before the customer returned for the bid, the printer would set a price and let every Association member know about the job and the price they were planning to quote. Once a bid was established, if the customer was unhappy with the quoted price and went to another Association member for a secondary bid, the member would be compelled by the Association to quote an even higher price. The only option for the customer was to try to find a printer who was not an Association member, and few printers could survive in Portland without the backing of the Franklin Association. Additionally, binders were so afraid of losing the business of Association members that they would often decline jobs from non-Association printers. ${ }^{22}$ In 1906 a Franklin Association lawyer named Ralph W. Wilbur addressed the widespread anti-trust charges, claiming,

There are a great many associations of this character here and all over the United States, and the question of their legality is constantly being brought into litigation. We had an example of that kind here in the City Retail Lumbermen's Association, which was forced down and out by the court decision that it was operating in restraint to interstate commerce, and therefore illegal. It was illegal, but I believe there are many associations here now that are sound. The test as to whether they are legally sound is. Are they morally sound? They must be formed to protect legitimate business. When they have an honest, legitimate object, they are not against the law. ${ }^{23}$

Wilbur's interpretation of the law was in line with legal precedent. Although the Sherman Antitrust Act of 1890 was intended to curtail monopolistic practices, enforcement of the Act was limited to large interstate businesses where competition had been entirely

\footnotetext{
${ }^{22}$ Ibid.

${ }^{23}$ Ibid., October 21, 1906, p. 12.
} 
eliminated. ${ }^{24}$ According to the legal scholar, Felix H. Levy, in the wake of U.S. v. C. Knight Co. (1892), the Sherman Act was, "virtually a "dead letter upon the statute book" until the Roosevelt administration began prosecuting violations of the Act in $1902 .{ }^{25}$ Even after enforcement began, local association like the Franklin Association avoided prosecution by not being an absolute monopoly. Ultimately the Franklin Association was compelled to curtail its price-fixing when the Clayton Antitrust Act (1914) extended the scope of the Sherman Antitrust Act to include price discrimination and exclusion. ${ }^{26}$

While the public may have been unhappy with the Franklin Association, its practices were crucial for the Metropolitan Press. From 1902 to 1914 the Binfords maximized the benefits of the Franklin Association to build strong bonds with their professional peers and clients, while remaining sheltered from the potential dangers of an oversaturated and highly competitive industry.

By the mid-1910s and the collapse of the Franklin Association, the Binfords were relatively well established as printers, but business still came in waves. During 1918, Peter Binford kept a journal that detailed the daily operations of the Metropolitan Press. The main source of steady income for the company was a contract with the Portland YMCA. ${ }^{27}$ The YMCA newsletter was issued twice a month and was usually formatted as

\footnotetext{
${ }^{24}$ Felix H. Levy, "The Federal Anit-Trust Law and the Rule of Reason," Virginia Law Review 1 (1913): 188-209; Felix H. Levy, "Should the Sherman Law Be Revised?" Virginia Law Review 6 (October 1919): $1-19$.

${ }^{25}$ Levy, "Should the Sherman Law Be Revised?" 191-93.

${ }^{26}$ Ibid.; Robert S. Schlossberg, ed., Mergers and Acquisitions: Understanding the Antitrust Issues (Chicago, IL: ABA Section of Antitrust Law, 2004); Douglas F. Broder, U.S. Antitrust Law and Enforcement: A Practice Introduction (New York, NY: Oxford University Press, 2010).

27 Journal of Peter Binford, June-August 1918, the Binfords \& Mort Papers, Box 1, Folder 4, Reed College Archives, Portland, OR.
} 
a four-page, single folded $11 \times 17$ inch sheet. ${ }^{28}$ Each finished newsletter was folded to standard letter size for mailing. This was a sizable job for the Metropolitan Press. ${ }^{29}$ The Binfords also secured a number of print jobs from the Portland Jewish community including the Jewish Tribune, a weekly paper printed from 1903-1922, which had the distinction of being the only Jewish paper in the Pacific Northwest during this period. ${ }^{30}$ At peak times, the Binfords had to hire temporary staff to run their presses. These workers were usually men that were employed by other print shops, but were willing to work nights to supplement their income. Peter Binford described staffing as a continual problem, particularly during World War I. Peter noted in his journal that women often applied for temporary work, but that he did not like hiring them because they lacked the physical strength and agility to operate the press properly. ${ }^{31}$

Although staffing the Metropolitan Press was difficult during peak printing days, on many days there was a shortage of work. On July 13, 1918, Peter Binford noted that he was having a hard time securing regular printing contracts. During the summer of 1918 Maurice Binford took a month-long vacation to the Oregon Coast, leaving Peter to run the entire operation on his own. The workload during this month was so light that during the weeks Peter was not working on the YMCA newsletter, he regularly took extended four-day weekends to go on family drives to the Columbia River Gorge, Mount Hood, and Stayton, where his wife's family lived. ${ }^{32}$

\footnotetext{
${ }^{28}$ YMCA Newsletters, the Records of the Portland YMCA, Lewis \& Clark College Special Collections, Portland, OR.

${ }^{29}$ Ibid.

${ }^{30}$ Journal of Peter Binford, June-August 1918, the Binfords \& Mort Papers, Box 1, Folder 4, Reed College Archives, Portland, OR.

${ }^{31}$ Ibid.

${ }^{32}$ Ibid.
} 
Despite the up and down nature of its business, the Metropolitan Press gradually expanded. In 1919 Peter and Maurice decided they had the resources and the need for another regular employee, and they hired their nephew Ralph Mort as an account manager. Mort had been working as a pressman for the Portland firm of Glass \& Prudhomme, with which he was considering a management job. ${ }^{33}$ The Binfords knew that Mort was a skilled printer and savvy businessmen and that, if he accepted a position elsewhere, they would lose a trusted colleague. To sweeten the deal, Peter and Maurice made Ralph Mort a full partner. ${ }^{34}$

As the business expanded, it moved to a brand new building named the Graphic Arts building on Ninth and Couch streets in northwest Portland. The Binfords financed the construction of the building, which was opened on April 9, $1921 .^{35}$ Initially, the threestory building housed the Metropolitan Press on the main floor, and the Portland Electrotype \& Stereotype Company on the second, while the Hall \& Emory Advertising agency shared the third floor with Peterson \& Schon Engraving. ${ }^{36}$ The new building completely changed the business model for the Metropolitan Press, and ownership of the building helped make the business profitable well into the second half of the twentieth century. The building included a print shop, editorial offices, and space for storing stock and supplies for the press, and provided regular monthly rental income. ${ }^{37}$

With expanded facilities, the ability to make greater investments in projects, and increasing demand, the firm expanded their operations to include books of varying

\footnotetext{
${ }^{33}$ Ibid.; and Richard Mort, interview by author, July 2007.

${ }^{34}$ Richard Mort, interview by author, July 2007.

${ }^{35}$ Oregonian, April 10, 1921, p. 8.

${ }^{36}$ Ibid.

${ }^{37}$ Binford, ed. Of Books \& Mortals, 2.
} 
quality, some of which were comparable to the fine press works produced by the Portland firm of F.W. Baltes. While many of the books produced by the firm were glorified promotional materials for companies and municipal organizations, some, like Bethenia Owens Adair work, Human Sterilization: Its Social and Legislative Aspects (1922), were central to social and scientific discussions of the period.

After Ralph Mort was made full partner, the three partners began to specialize in different phases of the business. Ralph Mort increasingly managed the presswork, and in 1930 he took over all facets of the job printing part of the company. ${ }^{38}$ Maurice increasingly oversaw the business side, including ordering supplies and marketing. When needed, he ran the press. ${ }^{39}$ Peter channeled his efforts into design, composition, typography, and proofreading. ${ }^{40}$ Without any formal training in design, Peter had a surprisingly good design sense, which he developed through collecting and studying fine press publications. ${ }^{41} \mathrm{He}$ even developed his own collection of books from various countries covering all eras of print including incunabula. ${ }^{42}$ Peter used this collection to develop a classic sense of typography and page layout, which was evident in many of the books published by the Metropolitan Press during the 1930s. In a 1947 interview with the Oregonian, Peter Binford remarked that he loved books for their, "binding, well-balanced typography, and above all, for the title page." 43

\footnotetext{
${ }^{38}$ Matthews, "Binfords \& Mort," 3; and Richard Mort, interview by author, July 2007.

${ }^{39}$ Matthews, "Binfords \& Mort," 3.

${ }^{40}$ Ibid.; and Richard Mort, interview by author, July 2007.

${ }^{41}$ Matthews, "Binfords \& Mort," 3.

${ }^{42}$ Records at Reed College show that Peter Binford owned an edition of Horace printed by Johann Gruninger in 1498. The Binfords \& Mort Papers, Box 1, Folder 6.

${ }^{43}$ Matthews, "Binfords \& Mort," 3.
} 
By the late 1920s Peter Binford, who always dreamed of publishing books that he liked to read had concluded that the Metropolitan Press could profit as the publisher of books about the Pacific Northwest. The number of self-published works that were being issued by Metropolitan Press and other job printers indicated that there was a ready market for local authors. The academic presses in the Pacific Northwest had failed to make an impact, and both general and scholarly audiences began to demand regional historical studies and regional fiction.

The Binfords were careful not to jump into a publishing endeavor that they could not sustain. In 1929 Peter Binford consulted with friends in Oregon's literary community about the viability of a publishing company in Portland. One of the Binfords' closest associates during these early years was Alfred Powers, the Dean of the Extension Program for the University of Oregon. Powers had taken an active interest in the publishing program at the University of Oregon, but the scope of this operation was limited to specialized academic works. Powers had a vision of a regional publishing operation that would issue works of fiction and non-fiction focused on the Pacific Northwest by local authors. It was little surprise that Powers reacted enthusiastically to Peter Binford's inquiry. Powers encouraged Binford to focus his publishing firm on works of regional importance that east coast publishers typically avoided. ${ }^{44}$ Even after Binfords \& Mort had established itself, Powers continued to insist that "Not enough western books are being published—certainly not enough in the big eastern publishing

\footnotetext{
${ }^{44}$ Ibid.
} 
centers. ${ }^{, 5}$ While H. L. Davis called for a more sophisticated brand of Oregon writing, Powers was the spokesperson for quantity over quality to help readers connect to their local history. Ultimately, Peter Binford's trust in Powers' vision would lead to financial success for Binfords \& Mort and shape Oregon literature in a way that permeated the Pacific Northwest much deeper than the Davis model.

In addition to Powers, Peter Binford consulted with the Portland author Sheba Hargreaves, John D. Guthrie of the U.S. Forest Service, Harriett C. Long of the Oregon State Library, and Howard McKinley Corning, a Portland poet and writer. ${ }^{46}$ All the consultants believed there was a healthy market for a publisher of this material. Peter Binford's business partners, Maurice Binford and Ralph Mort, also agreed that the project was worth pursuing if Peter assumed primary responsibility for it. Given the state of the economy in 1929 and 1930, Metropolitan's confidence in the success of this operation was remarkable. This confidence was rooted in the popularity of regional literature and the safety net provided by the job printing division of Metropolitan.

In 1930 the Metropolitan Publishing Company launched its regional publishing division. The company encountered a few initial problems. It was probably a mistake to choose to use the same name (Metropolitan) for both the publishing and job printing parts of the company. The distinction between the two was blurry, but generally, when the company published books, Metropolitan edited and funded the printing, distribution, and advertising for the book. Authors of published books usually signed a contract that assigned sole and exclusive publication rights to the Binfords and stipulated royalty

\footnotetext{
${ }^{45}$ Alfred Powers, "Chronicle of Western Books Published in 1941," Oregon Historical Quarterly 43 (1941): 66.

${ }^{46}$ Ibid.
} 
payments of ten percent per book for every book sold after initial sales of five thousand dollars. ${ }^{47}$ Books that were "printed" rather than "published" were edited and completely paid for by the client. Usually the client was also responsible for distribution, and Metropolitan did not make any money from sales. Many of the books the company printed as job printers, particularly religious and philosophical works like James Lively's Science of Mind or Individual and Communal Knowledge (1933) William Radke's Time and Space Relative to the Recorded History in the Span of Human Existence (1937), and Frank Robinson's Gleams Over the Horizon (1939), were of poor quality, and as a result the reputation of the publishing operation may have suffered in the eyes of readers and critics. This problem was eventually remedied by replacing the name Metropolitan with Binfords \& Mort.

The structure of the Binfords standard publishing contract was carefully designed to minimize risk. They made it standard practice to publish in large print runs. One of the largest expenses in printing was in typesetting and the setup of the press. By printing large numbers of books, the company ensured that when a book sold well, they would maximize their profits by not having to repeat these tasks when reprinting. Usually the company would further save money by binding only a small part of the print run, and waiting for initial sales income before binding the rest. ${ }^{48}$ The downside of this strategy was that it required a larger initial investment in printing, which was one of the main reasons the Binfords stipulated that royalties would only be paid after initial sales of five thousand dollars. This was roughly equivalent to 1,000 copies at a retail cost of five

\footnotetext{
${ }^{47}$ Based on the Binfords \& Mort contract for the Dictionary of Oregon History at the Oregon State Library Special Collections, WPA Collection, Series 3, Box 109, Salem, OR.

${ }^{48}$ The binding practices were determined after examining numerous Binfords \& Mort books.
} 
dollars, or 1,666 copies for copies sold at a wholesale rate to bookstores like J.K. Gill and Meier and Frank. ${ }^{49}$ The structure of these contracts was shrewd and realistic, and it was probably one of the main reasons that the company remained financially viable for at least thirty years. It should also be noted that, although none of Binfords' authors became rich through the publications of their books, the standard contract would have been considered more than satisfactory to most authors. In most cases the books would not have been accepted by other publishers, and most Oregon authors during this era were used to financing the printing and distribution of their books. The contract offered by the Binfords was quite favorable given the alternative.

While Peter Binford could take credit for the high quality of the Metropolitan Press's book designs, the content was directly attributable to Alfred Powers. Shortly after opening publishing operations, Peter Binford retained Alfred Powers as a contract editor. He was eventually given a permanent position and an editor's office in the Graphic Arts building. For the first twenty years of the company Powers' influence on both manuscripts and book format was immense. ${ }^{50}$ While it is difficult to document the extent of Power's influence, there is ample evidence that Powers and Peter Binford were extremely close. A letter written toward the end of Powers' life to Peter Binford's widow Sylvia notes how much he missed his work and his friendship with Peter. ${ }^{51}$ Surviving copies of books by Powers inscribed to Binford attest to the closeness of their

\footnotetext{
${ }^{49}$ Although the wholesale rates for books have fluctuated, for most of the twentieth century they were consistently set near forty percent. Michael Winship, "The Rise of a National Book Trade System in the United States," in Print in Motion: The Expansion of Publishing and Reading in the United States, 18801940, eds. Carl Kaestle and Janice A. Radway (Chapel Hill, NC: University of North Carolina Press, 2009), 62.

${ }^{50}$ Ayres, "The History of Binfords and Mort," 35; and Binford, ed. Of Books \& Mortals, 2.

${ }^{51}$ Letter from Alfred Powers to Sylvia Binford, August 10, 1960, Binfords \& Mort Papers, box 1, folder 3. Reed College Archives, Portland, OR.
} 
relationship. An inscription in Powers' Redwood Country reads, “To Peter Binford who for twenty years has had a special place in my affections and admiration." 52

The first book published by Metropolitan was Marooned in Crater Lake by Alfred Powers, which retailed for $\$ 1.75$. This work of Oregon fiction was intended for school libraries and a general juvenile audience, for which there was a shortage of quality titles set in Oregon. Organizations like the Inland Empire Council of Teachers of English had been making a concerted effort to encourage the publication of regional titles and were committed to alerting teachers through newsletters and bibliographies to regional books worthy of use in the classroom. ${ }^{53}$

Praise for Marooned in Crater Lake was immediate. George Halling of Portland's leading bookseller, J.K. Gill, wrote, "The order for Marooned in Crater Lake was the largest ever placed by the school libraries of Oregon for a single book." ${ }^{54}$ Oregon's Assistant State Superintendent of Public Instruction, James Burgess, wrote, "At last a real book of real Oregon stories by a real Oregon author." Schools "cannot afford to be without the book." ${ }^{55}$ As educators swooned, reviewers for the Oregonian, Oakland Tribune, and Salt Lake Tribune also found the book well written, enjoyable, and filled with a sense of Oregon, without resorting to the familiar formula of the Western novel. ${ }^{56}$

\footnotetext{
52 This inscription is from the copy of Alfred Powers, Redwood Country (New York, NY: Duell, Sloan \& Pearce, 1949) in the Marylhurst University Library. Marylhurst was the recipient of 870 books given by one of Binfords \& Mort's most senior editors, Laura Phillips. The Phillips gift included many of Peter Binfords personal copies of books printed by the company.

${ }^{53}$ See Northwest Books: Report of the Committee of Books of the Inland Empire Council of Teachers of English (Portland, OR: Binfords \& Mort, 1942).

${ }^{54}$ From promotional quotes printed on the inside of the jacket for Paul Hosmer, Now We're Loggin' (Portland, OR: Metropolitan Press, 1930).

55 Ibid.; and James M. Burgess, “New Books,” Oregon Education Journal 5 (October 1930): 37.

${ }^{56}$ From reviews of Marooned in Crater Lake printed on the inside of the jacket of: Hosmer, Now We're Loggin.'
} 
There is little doubt that Marooned in Crater Lake was a financial success for Metropolitan Press. It was issued in three separate printings in 1930. The first printing sold out almost immediately, and a second printing followed in the same year. A third limited edition printing of three hundred copies bound in myrtle wood, an ornamental wood native to Southern Oregon, was also issued in 1930. These deluxe copies retailed for six dollars.

Metropolitan's second publication was a reprint of Cathlamet on the Columbia (1930), a short historical recollection of the Chinook Indians by Thomas Nelson Strong, who had been born at the Cathlamet village in $1853 .{ }^{57}$ The Holly Press of Portland had printed the original edition in a small leatherette edition of two hundred copies in 1906. Copies of the work had long ceased to be available from booksellers. Peter Binford's own experience of growing up in an Indian community mirrored Strong's and contributed to his sense of the book's importance. After obtaining rights to it from Strong, Metropolitan commissioned the distinguished University of California anthropologist A.L. Kroeber to write a preface to the book. Peter Binford carefully handset and designed the entire book. The pages were printed on high quality paper made by Blake, Moffit, \& Towne in Portland. The text included chapters with ornate colored initial capitals. The end result was a beautiful book that received compliments from America's leading fine press printer, John Henry Nash. ${ }^{58}$ Despite its high production values, it was priced at only two dollars, making it comparable in price to books with inferior production values published

\footnotetext{
${ }^{57}$ Powers, History of Oregon Literature, 375-377.

${ }^{58}$ Matthews, "Binfords \& Mort," 3.
} 
by major eastern publishers. ${ }^{59}$ Cathlamet went into multiple printings, and Peter Binford proved with his first publication that the Metropolitan Press could produce a high quality book of regional literature at a price attractive to the consumer.

Other titles issued during Metropolitan's inaugural year included two small poetry books, The Mountain in the Sky by Howard McKinley Corning, and Desert Poems by Ada Hastings Hedges. These books retailed for $\$ 1.25$ each. The firm also issued a personal narrative about the logging industry titled Now We're Loggin' by Paul Hosmer, which retailed for two dollars. In 1930 the Binfords published only five titles (the firm would average twelve titles a year from 1930 to 1960), but the range of material, which included poetry, juvenile literature, history, and native American studies, was reflective of what the firm would produce in the future.

Despite initial successes with books like Marooned in Crater Lake, the Great Depression and a lack of spending money among the general population put a damper on Metropolitan's sales during the early nineteen thirties. Richard Mort, the son of Ralph Mort, remembered months in the early thirties when the paychecks of the three partners had to be used to pay the salaries of the company's employees. ${ }^{60}$ But just as the YMCA contract had provided steady income during the early years of the Metropolitan Press, securing contracts for the publication of WPA state guidebooks for Oregon, Nevada, and Washington now provided reliable income for the publisher.

After seven years of building a national reputation as a publisher, the Metropolitan Publishing Company began to attract the attention of some east coast

\footnotetext{
${ }^{59}$ As a point of comparison, a year earlier Ernest Hemingway's A Farewell to Arms retailed at \$2.50.

${ }^{60}$ Richard Mort, interview by author, July 2007.
} 
publishers and critics. The William Morrow Company of New York sought a closer business relationship with Metropolitan. In 1937 officials from Morrow strongly encouraged the Binfords to change the name of their company ${ }^{61}$ Almost every city in the country had a "metropolitan press," and the name did nothing to help market the books or make them stand out in any way to potential buyers. Taking this advice to heart, the three partners changed the name of the publishing company to Binfords \& Mort. They retained the name Metropolitan Press for their job printing business. The first title to bear the new imprint was a small pamphlet by Wert Emmit Moore titled Home Again, which was undated except for a note that the essay had been written in 1937; it was likely published in early 1938. At the same time that they changed their name, the company also adopted the logo of a circuit rider with Mount Hood in the background and the slogan "By the Pacific." The circuit rider logo paid homage to Oregon's missionary heritage. It was modeled after a statue by A. Phimister Proctor that was given to the State of Oregon for display on the capitol grounds in 1924.

In 1938, shortly after the company name was changed, the William Morrow Company made a formal agreement with Binfords \& Mort to be their "sales agents and distributors." The agreement only lasted for one year. Presumably Morrow did not make enough money to continue. For Binfords \& Mort, however, the short relationship placed their books in the hands of readers far beyond the Pacific Northwest. ${ }^{62}$

${ }^{61}$ Matthews, "Binfords \& Mort," 3; and Ayres, "The History of Binfords and Mort," 35; and Binford, ed. Of Books \& Mortals, 2.

${ }^{62}$ Matthews, "Binfords \& Mort," 3; and Ayres, "The History of Binfords and Mort," 35; and Binford, ed. Of Books \& Mortals, 2. Many of the Binfords \& Mort titles issued during the year 1938 included a note on the copyright and jacket stating, "Morrow \& Company, Sales Agents and Distributors, 386 Fourth Avenue, New York." Details of this relationship remain elusive. Documentation probably exists in the Binford \& 
Operations for Binfords \& Mort remained fairly stable during World War II, which was consistent with national publishing trends. ${ }^{63}$ Across the United States, the sales of many publishers actually increased as war-workers flush with cash and eager for information bought books. ${ }^{64}$ For Binfords \& Mort, the number of titles issued each year during the War dropped by around ten to twenty percent, mainly because the Binfords were conservative in projecting sales and, as a relatively small publisher, paper shortages caused by a decrease in forestry work and paper production and paper rationing by the War Production Board made book production more expensive. ${ }^{65}$ By 1944 , the War Production Board had restricted paper usage to thirty-five percent of pre-war levels. ${ }^{66}$ Instead of issuing the occasional elaborately hand-printed and bound editions they had issued in the 1930s, the Binfords stuck with standard size books with plain bindings and lower grades of paper. Overall, the firm did surprisingly well at maintaining its readership and the quality of its publications during this time of paper shortages, restricted budgets, and an overall drain of literary talent.

\footnotetext{
Mort corporate archives, but these are not open for research. William Morrow is now a subsidiary of the Harper Collins conglomerate and their archives are also unavailable for research.

${ }^{63}$ James L. W. West III, "The Expansion of the National Book Trade System" in Print in Motion: The Expansion of Publishing and Reading in the United States, 1880-1940, eds. Janice A. Radway and Carl F. Kaestle (Chapel Hill, NC: University of North Carolina Press, 2009), 81.

${ }^{64}$ Ibid.

${ }^{65}$ Beth Luey, "The Organization of the Book Publishing Industry," in The Enduring Book: Print Culture in Postwar America ed. David Paul Nort, et al. (Chapel Hill, NC: University of North Carolina Press, 2009), 29; and Gordon B. Neavill, "Publishing in Wartime: The Modern Library Series During the Second World War," Library Trends 55.3 (2007): 583.

${ }^{66}$ Neavill, "Publishing in Wartime," 587.
} 
Table 1: Binfords \& Mort Titles Published from 1940 to 1947

\begin{tabular}{|l|r|r|r|r|r|r|r|r|}
\hline & 1940 & 1941 & 1942 & 1943 & 1944 & 1945 & 1946 & 1947 \\
\hline $\begin{array}{l}\text { Number } \\
\text { of Titles } \\
\text { Published }\end{array}$ & 13 & 13 & 13 & 7 & 6 & $10^{*}$ & 13 & 10 \\
\hline
\end{tabular}

The totals in this table do not include books that were job printed, or pamphlets that were not casebound. Years shaded in gray are the years that the United States was engaged in World War II.

* Four of these titles were children's books of less than 50 pages.

At the close of World War II Binfords \& Mort underwent major changes. In 1947 the Binfords and Ralph Mort decided to sell their interest in the job printing part of the business, still known as the Metropolitan Press. The purchaser was a local newspaper publisher, Sheldon F. Sackett. Sackett made an initial down payment of $\$ 290,000$, and over the course of the next fifteen years he paid the Binfords and Ralph Mort an additional $\$ 710,000$ plus three and a half percent interest. ${ }^{67}$ Terms of the sale also stipulated that Peter and Maurice Binford, as well as Peter's son, Thomas, and Maurice's sons, Maurice, Jr. and Ormond, would remain as advisors for the printing company. Ralph Mort was retained as general superintendent of the Metropolitan Press. ${ }^{68}$

Although the Binfords maintained a close relationship with the Metropolitan Press, after the sale was finalized they were able to channel more of their time and energies into the Binfords \& Mort publishing company. With cash from the sale, they began construction on a new building next door to the Graphic Arts building, which was finished in $1949 .{ }^{69}$ This building was specially designed to house a one-half block-long perfect binder that allowed the Binfords to print paperback editions of their books, giving

${ }^{67}$ Oregonian, April 4, 1947, p. 10.

${ }^{68}$ Ibid.

${ }^{69}$ Binford, ed. Of Books \& Mortals, 2. 
the company a larger profit margin. They were also able to bid on contracts for telephone directory printing. ${ }^{70}$ By 1958 the firm had contracts for phone books with thirty-six cities across the Pacific Northwest. ${ }^{71}$

As the terms of sale for the Metropolitan Press indicated, the second generation of Binfords transitioned into the management of the publishing company. Thomas Binford, Peter's son, had studied journalism and printing at the University of Oregon prior to World War II. In 1934 he collaborated with another University of Oregon student, Myron Ricketts, to design, set, and print Memaloose, a small edition of three poems and two prose pieces by Frederic Homer Balch, author of The Bridge of the Gods. ${ }^{72}$ The project was done under the direction of the distinguished fine press printer John Henry Nash, who ran the printing program at the University of Oregon from 1938 to $1943 .{ }^{73}$ The Memaloose project benefited from the assistance of Alfred Powers, who wrote the introduction to the book and solicited the unpublished manuscript from Balch's sister Gertrude Balch Ingalls. ${ }^{74}$ Although Thomas studied under one of the greatest American book designers, Memaloose was probably the only book Thomas ever helped design that could be considered beautiful in the fine press tradition. Later examples of Thomas's design work exhibited a poor sense of typography and graphic design. ${ }^{75}$ Despite these

\footnotetext{
${ }^{70}$ Ibid., 3.

${ }^{71}$ Oregonian, January 12, 1958, p. 7A.

${ }^{72}$ Frederic Homer Balch, Memaloose (Portland, OR: Privately Printed by Myron Rickets \& Thomas Binford, 1934). This book was issued in an edition of 105 copies.

${ }^{73}$ Robert Harlan, John Henry Nash: The Biography of a Career (Berkeley, CA: University of California Press, 1970), 107.

${ }^{74}$ Balch, Memaloose; the manuscripts for this book and the correspondence between Gertrude Balch Ingalls and Alfred Powers are included in the Alfred Powers Papers, 1834-1963, Mss. 2907, Box 2, Folder 3, Oregon Historical Society, Portland, OR.

${ }^{75}$ Most of the books issued by Binfords \& Mort during Thomas Binford's tenure employed gaudy colors and crude illustrations, but Martha Montague's Lewis and Clark College, 1867-1967 (1967) is a
} 
shortcomings, Thomas was interested in Pacific Northwest literature and the publishing business. After he returned from the war in 1946, Thomas was promoted to general manager of Binfords \& Mort. ${ }^{76}$

Maurice Binford had two sons who also became employees of the company after the war. Ormond Binford had studied printing at the Carnegie Institute in Pittsburgh. In 1946 Ormond was made assistant manager of Binfords \& Mort, and for a time during the 1950s he became the public face of the company through extensive public service with the Portland Junior Chamber of Commerce, the Portland Retail Trade Bureau, March of Dimes, Red Cross, Community Chest, United Fund, and Portland City Club. ${ }^{77}$ Maurice, Jr. returned after the war to a job as general manager of the Metropolitan Press and became well known throughout the Portland area for his work in developing foreign exchange programs for high school students. ${ }^{78}$

Although the sons were given high-level positions within the company, Peter and Maurice, Sr. remained intimately involved with the company for a number of years (until 1959 and 1953 respectively), which kept the book quality at a high level. During the 1950s, when the first and second generations worked together, Binfords \& Mort produced some of its most important books. During this period they acquired the copyright for Washington Irving's Astoria and Adventures of Captain Bonneville. Sales of these

particularly ugly book. The book features a jacket with a sickly colored green background. The text on the back panel has a 1.5 inch margin on the top and a .25 inch margin on the bottom, making it obviously offcentered. The case binding is covered in a metallic gold buckram material that has developed a white filmy coating over time that is sticky and resembles mold. The typography of the book makes the text appear crowded and the house typeface has a blocky typewriter-like appearance.

${ }^{76}$ Matthews, "Binfords \& Mort," 3.

${ }^{77}$ Ibid.; Oregonian, January 18, 1953, p. 24; Ibid., December 12, 1942, p. 5; Ibid., November 13, 1950, p. 10; Ibid., January 14, 1951, p. 21; Ibid., October 29, 1952, p. 18.

${ }^{78}$ Oregonian, December 11, 1953, p. 21. 
reprints provided steady income for the next fifty years. They also published important reference works like Charles W. Smith's Pacific Northwest Americana: A Check List of Books and Pamphlets Relating to the History of the Pacific Northwest and the Dictionary of Oregon History. Binfords \& Mort also initiated a series of county histories for the state of Oregon, many of which remain standard historical references. For more casual readers, the company published biographies of significant Pacific Northwest figures including Opal Whitely, Isaac Ingalls Stevens, Peter French, and John McLoughlin.

At the beginning of the 1950s the company was turning a respectable profit and generating a fair amount of media attention. In 1951 the American Mercury described Binfords \& Mort as an interesting model for a publishing company. Where larger firms positioned to appeal to a general audience were struggling, Binfords \& Mort was succeeding by specializing. According to the American Mercury, Binfords \& Mort was publishing about twenty volumes per year in editions of four to five thousand copies per book. Ninety-five percent of these books were profitable compared to mainstream publishers, where seventy-five percent of their output lost money. ${ }^{79}$ Binfords \& Mort even attracted the attention of Hollywood, which turned two of their books into movies. ${ }^{80}$ Portlander Claire Phillips' Manila Espionage, an autobiographical account of her time as a cabaret dancer and American spy in the Philippines during World War II, was adapted for the screen as I Was an American Spy (1951). Sacajawea of the Shoshones (1943) by Della Gould Emmons was adapted in 1955 for the Charlton Heston and Donna Reed film, Far Horizons. In 1954 the Oregonian claimed that Binfords \& Mort was the largest

\footnotetext{
${ }^{79}$ Ibid., November 19, 1951, p. 15.

${ }^{80}$ Ibid., January 12, 1958, p. 7A.
} 
publishing house west of the Mississippi ${ }^{81}$ The claim is debatable, but it was made when local pride in the company was at its peak and the Oregon Advertising Club had just honored the achievements of the publisher with a banquet featuring forty Binfords \& Mort authors. ${ }^{82}$

Although the job printing side of the Binford family company, the Metropolitan Press, was officially sold in 1949, members of the Binford and Mort families purchased and maintained stock in the press. They also continued to work for Metropolitan under the new owner. As a result, the profitable job printing business was sometimes used to support the marginally profitable publishing operation. In 1953 the Metropolitan Press won a $\$ 300,000$ contract to print a six-volume set of the Oregon Revised Statutes. ${ }^{83}$

In the midst of this success, Maurice, Sr. died from a brain aneurism on April 16, 1953. ${ }^{84}$ Maurice had worked up to the week before his death, which left a void in the critical areas of budgeting and marketing. Perhaps seeing the sudden way in which Maurice's life had ended, Peter gradually began to separate himself from the office. In 1953 he purchased a dairy farm in Gresham and increasingly spent time away from the office. ${ }^{85}$ In 1956 he was awarded an honorary Doctor of Humane letters degree by Linfield College, to which he had donated eighty-five Binfords \& Mort titles and helped endow a chair in the history department. ${ }^{86}$ October 26,1959 , marked the end of an era, when Peter died at the age of eighty-three. ${ }^{87}$ The loss of his knowledge and passion for

\footnotetext{
${ }^{81}$ Ibid., April 17, 1954, p. 7.

${ }^{82}$ Ibid., March 25, 1954, p. 17.

${ }^{83}$ Ibid., December 11, 1953, p. 21.

${ }^{84}$ Ibid., April 17, 1954, p. 7.

${ }^{85}$ Ibid., December 13, 1953, p. 7.

${ }^{86}$ Ibid., October 27, 1959, p. 15; Ibid. January 4, 1957, p. 5.

${ }^{87}$ Ibid., October 27, 1959, p. 15.
} 
the Pacific Northwest would prove to be a loss from which the company would never recover.

With the passing of his father and his uncle, Thomas Binford took on responsibility for book selection and design; marketing increasingly rested on his shoulders. For a few years, Thomas relied on the guidance of Alfred Powers, who remained as an editor until 1961. Because of his knowledge of and enthusiasm for Oregon history and literature, Alfred Powers' retirement as editor was a great loss. ${ }^{88}$ Powers was replaced by Thomas's close friend Laura K. Phillips, who joined the Binfords \& Mort staff shortly after Thomas returned from World War II. ${ }^{89}$ Phillips never had Powers' penchant for finding compelling books, and because Thomas's publication choices were questionable, Phillips rarely worked with high quality manuscripts. Rudolph Ernst, the company binder, a highly skilled employee, was gradually phased out of the company. Ernst had been working for the company since the early 1930s and was respected throughout the Pacific Northwest printing community for his skills in both hand and machine binding. ${ }^{90}$ Ernst continued to work for another ten years after Peter Binford's death, but under Thomas's direction he was reassigned to the job of Metropolitan Press plant superintendent. Without Peter Binford's interest in quality binding and the direct involvement and skills of Rudolph Ernst, investment in binding gradually decreased and the overall quality of Binfords \& Mort books declined..$^{91}$ In 1970 ,

\footnotetext{
${ }^{88}$ Oregonian, August 20, 1961, p. 43.

${ }^{89}$ Laura K. Phillips Revocable Living Trust Agreement, June 1, 1998, Marylhurst University, Portland, OR; Oregonian, June 25, 2000, p. C09.

${ }^{90}$ Ernst was honored for his accomplishments by the Portland Club of Lithographers and Printing House Craftsmen in 1987. Oregonian, June 6, 1989, p. C09.

${ }^{91}$ Ibid.
} 
the same year that Ernst retired, the Metropolitan Press lost its lucrative telephone directory contract for the city of Portland. Less than eight years later the company went bankrupt. $^{92}$

In 1973 Thomas Binford bought out his cousins' interest in Binfords \& Mort. This was probably a good solution for everyone involved, since books sales were diminishing and Thomas was not interested in altering his operating practices. This meant costs were cut on production quality, marketing, and distribution. Thomas made the unusual decision of changing the company name to Binford (singular) \& Mort to reflect the fact that he was the sole Binford involved with the firm. Until his death in 1983, Thomas continued to issue less and less interesting titles. ${ }^{93}$

After Thomas's death, the Binford estate sold the company to James Gardenier. ${ }^{94}$ Gardenier had worked in the publishing industry and developed a bond with Thomas Binford prior to his death. Gardenier's retirement project of reviving the company was a massive undertaking. By 1984 Binford \& Mort had ceased to produce books of any real scholarly or literary merit. Some were curiosities, but even as curiosities the books failed to generate readers or book buyers. In 1983 the firm issued only six titles. Five of the six (Country Chaff by Jerry Easterling, The Hope Truckline and 75 Miles of Women by Dennie McCart, Blood on the Half Shell by Al Qualman, "Schoolmarms" and Shaniko

\footnotetext{
${ }^{92}$ Ibid., March 8, 1978, p. D6.

${ }^{93}$ Ibid., March 15, 1983 p. D16. Examples of some of Binfords \& Mort's titles during this period that lacked any regional historical or literary relevance include, Elmer Caldwell's Travel Babble (1972), Richard Washburn's Pathways of My Thought (1975), Larry Powell's Big Book of Cake Decorating (1977), Dick Walker's Do Not Test Us: One Man's Ventures Into the Psychic World (1978), L.A. DuBose's Revelation Discovered: The Code of the Book (1980), Gerry Frank's Where to Find It, Buy It, Eat It, and Save Time and Money in New York (1980), and Stan Allyn's Heave To, You'll Drown Yourselves! (1982).

${ }^{94}$ Paul Pintarch, "Publishing from the Bottom Shelf Up," Oregonian Northwest Magazine, January 8, 1984, p. 128.
} 
People by Helen Rees) were poorly written and edited, and featured awful typography, printing, and binding. The single exception was Ralph Preston's Early California Atlas, which was a reprint. In addition to putting out inferior products, Thomas Binford had also burned bridges with booksellers and distributors. In an interview with the Oregonian conducted shortly after he purchased the company, Gardenier noted that he believed the company could be a success, if "I can just get it back in everyone's good graces again. Until now, the philosophy has been, 'We got books. If you want them, we'll send them to you.' We've got to change all that." ${ }^{95}$ Gardenier also believed that the backlist, which included works like Washington Irving's Astoria and Frederick Homer Balch's Bridge of the Gods, would prove to be good sellers if marketed properly. ${ }^{96}$

Over the next seventeen years Gardenier had modest success in improving the fortune of the Binford \& Mort publishing company. Typeface selection, illustration, and jacket design were appealing for the first time since the graphic design standards and production values for Binfords \& Mort peaked in the mid-1940s. It was actually possible that a book buyer might be attracted to the look of the book on the shelf. For the first time in many years Binford \& Mort issued some important historical reference works that were properly researched and edited, such as the multivolume Catholic Church Records of the Pacific Northwest, the 1,180 page Oregon Burial Site Guide, and a handful of books about the history of Portland by Eugene Snyder, including We Claimed This Land: Portland's Pioneer Settlers, and Portland Potpourri: Art, Fountains \& Old Friends.

\footnotetext{
${ }^{95}$ Ibid.

${ }^{96}$ Ibid.
} 
These books garnered local praise in the Oregonian book section and were added to library reference collections.

These successes were short lived. By the end of the twentieth century, the book industry was undergoing major changes as a result of the internet. Ultimately Gardenier's efforts were not enough to resuscitate Binford \& Mort. In March of 2000 Gardenier died, and the responsibility for managing Binford \& Mort passed to his wife Polly. ${ }^{97}$ By this point in time, the company was not bringing in enough money to merit hiring staff. Without the ability to maintain robust editorial, design, printing, and distribution functions, Polly and her daughter were forced to absorb the entire workload for the company. ${ }^{98}$ In 2010 Polly Gardenier moved the remaining Binford \& Mort stock out of her Hillsboro, Oregon, warehouse space. Although she still owned the name and publication rights of Binford \& Mort, the company ceased to function as a publisher.

\footnotetext{
${ }^{97}$ Oregonian, March 30, 2000, p. D13.

${ }^{98}$ John Henley, interview by author, September 15, 2007.
} 


\section{THE BINFORDS \& MORT LITERARY SENSIBILITY}

From 1930 to 1960 Binfords \& Mort was the primary publishing force behind a developing Oregon literary sensibility based on local works of natural history, history, children's literature, fiction, and poetry. Alfred Powers and the Binfords found that these five genres all incorporated regional language and settings that were crucial to selling regional literature. These genres all capitalized to varying degrees on nostalgia for the pioneer era to form a body of local legend and lore that provided residents with an identity that differentiated them from the rest of the United States. Even Binfords \& Mort's natural history texts tapped into this nostalgia by invoking images of the "untamed wilderness" encountered by pioneers.

The literary sensibility that Binfords \& Mort fostered differed from that adhered to by H. L. Davis and other writers with a national following. Like the Binfords, Davis believed that regional literature should employ local language and distinctive settings, but he had no use for nostalgia, which he termed as "emotional indigestion."1 Regardless of whether or not Powers and the Binfords shared Davis's opinions about nostalgia (presumably they did not), customer demand ultimately informed the literary sensibility of the books that Binfords \& Mort sold, and in Oregon emotional indigestion sold well.

Binfords \& Mort's publication of Pacific Northwest natural history texts proved to be an important part of the company's catalog. Although inherently different from the romantic legends presented in Binfords' fiction, natural history texts nevertheless contributed to the overall lore of the region. There is ample evidence that both readers

\footnotetext{
${ }^{1}$ H. L. Davis and James Stevens, Status Rerum: A Manifesto Upon the Present Condition of Northwestern Literature, Containing Several Near-libelous Uttrances, Upon Persons in the Public Eye (The Dalles, OR: Printed Privately for the Craft, 1927), 1
} 
and local critics placed natural history within the larger category of Oregon literature. In a 1936 article for the Oregonian titled "Oregon Becomes Active Center for Writers," Eleanor Allen, a Portland poet and writer, highlighted natural history in her outline of what she believed were the main types of Oregon literature. ${ }^{2}$

Binfords \& Mort issued its first natural history texts in 1932, two years after entering the publishing field. The first two natural history texts they published were BirdWatching in the West by Frances Staver Twining, an avid bird-watcher and writer for the Oregonian, and Roadside Flowers of the Pacific Northwest by Drew Sherrard, a garden expert and columnist for the Oregonian. Bird-Watching was a transitional work that paired literary elements familiar to Metropolitan's readers with a scientific foundation. Superficially, the book was designed and formatted to look exactly like Binfords' previous works of fiction, poetry, and history. ${ }^{3}$ In terms of content, the work was primarily made up of the author's personal reflections on bird watching illustrated with stunning woodcut illustrations. The jacket claimed, "This book...contains true stories of intimate contacts with birds. The story of the friendship between the author and the chickadee is worth the price of the book alone."4 The purely scientific elements of the book included a regional bird list and instructions on bird identification. The pairing of a scientific text about the western environment with personal anecdotes to interpret the science was similar to the successful model established by John Muir.

The Oregonian review of Twining's Bird-Watching in the West was glowing:

\footnotetext{
${ }^{2}$ Oregonian, March 29, 1936, p. 58.

${ }^{3}$ The standard size for most Binfords \& Mort books from this period was $20.5 \mathrm{~cm}$ high by $14 \mathrm{~cm}$ wide.

${ }^{4}$ From the jacket of Frances Staver Twining, Bird-Watching in the West (Portland, OR: Metropolitan Press, 1932).
} 
It is almost like having the blue bird come. For long years folk have waited for a readable book telling about the birds all around us, birds that visit Oregon every year, birds that waken us in the mornings and some that sing lullabies at eventide. And here it is, a charming, handy, happily printed book ... The printing is a true work of art, and was in Portland, too, by the Metropolitan Press. ${ }^{5}$

Roadside Flowers of the Pacific Northwest was also formatted to look like

Binfords' literary texts. The short text of the book included a general description of

Pacific Northwest wildflowers, where and when they grew, and a detailed listing of typical wildflowers from the various climatic zones of the Pacific Northwest. The book was issued with four packets of native wildflower seeds: iris, camas, bleeding heart, and lupine. By issuing seeds to their readers, the author was making a statement about the importance of the environment. Regardless of where a person might live, they could still retain the identity of a Pacific Northwesterner by surrounding themselves with local plants. As in the review for Bird-Watching in the West, the Oregonian review for Roadside Flowers praised the book for having a wide appeal beyond specialists. ${ }^{6}$ This initial foray into the publication of natural history texts was successful with Binfords' readers and, as a result, the firm continued to issue a range of similar books. ${ }^{7}$ Some of their publications became standard reference works. ${ }^{8}$ Leonard Ekman's Scenic

\footnotetext{
${ }^{5}$ Oregonian, December 13, 1931, p. 6.

${ }^{6}$ Ibid., August 4, 1932, p. 12.

${ }^{7}$ The success and popularity of these texts can be extrapolated by looking at the number of times each title was revised and reprinted, as well as the number of WorldCat libraries (http://firstsearch.oclc.org) that hold each title. Most of these works were reprinted, meaning their first printings sold out. Additionally, these titles can be found in between 200 and 400 WorldCat libraries, which is a relatively high figure considering there are many more libraries today. Modern best-sellers like a works by John Grisham can be found in around two to three thousand libraries, while the most modern academic monographs can be found in between 400 and 1,500 libraries.

${ }^{8}$ Some of the key scientific reference works published by Binfords \& Mort included: Enari's Plants of the Pacific Northwest (1956), Frye's Ferns of the Northwest (1934), Gilkey's Handbook of Northwest Flowering Plants (1951), and Guberlet's Animals of the Seashore (1936). Other works, though scientific in intent, took a narrative approach like Ekman's Scenic Geology of the Pacific Northwest (1959) and Strong's Stone Age on the Columbia River (1959).
} 
Geology of the Pacific Northwest was issued in three separate editions and numerous printings, while Stone Age on the Columbia by Emory Strong was issued in four editions. Appealing to both specialists and the general reader, Stone Age on the Columbia was one of Binfords \& Mort's most popular books. The book's author Emory Strong proved to be an effective promoter. In addition to attending public book signings, Strong appeared on Portland's KOIN television to promote the book and curated an exhibit of Native American artifacts at the Oregon Museum of Science and industry. ${ }^{9}$ Although natural history was never the primary focus of Binfords \& Mort's publishing catalog, the natural environment was a crucial part of regional identity, and as a result careful selected texts like Stone Age on the Columbia became steady sellers.

Works of history were also given high priority for publication by Binfords \& Mort. Historical texts appealed to the nostalgic side of many Oregonians. Even reference works like the Dictionary of Oregon History helped a growing number of amateur historians and writers engaged in writing to satisfy their nostalgia for the pioneer period.

During the company's first year, Peter Binford began the profitable business of buying rights and reprinting interesting historical texts. The first of these reprints was Thomas Nelson Strong's Cathlamet on the Columbia. This strategy was also used for the publication of Oregon Geographic Names before the rights were turned over to the Oregon Historical Society Press in the 1960s. Prior to the founding of the Metropolitan Publishing Company Lewis A. McArthur had funded a small printing of a first edition of Oregon Geographic Names. The work was an attempt to provide a history for every place name in Oregon. McArthur's work established the uniqueness of Oregon's vernacular,

${ }^{9}$ Oregonian, September 15, 1959, p. 33. 
which H.L. Menken praised in the second supplement to The American Language. Almost every entry in Oregon Geographic Names illustrates how McArthur was compiling lore and endowing it with importance. For example, the entry for "Freezeout Ridge" reads, "This long north and south ridge about 13 miles east of Heppner divides the headwaters of Willow and Butter creeks. It was named in 1899 when John Kilkenny and James Carty lost 1000 head of sheep in a spring blizzard after shearing." ${ }^{10}$ A simple unremarkable story of raising sheep was elevated to local legend in this publication. McArthur's first printing was a small print run and barely received notice among Oregon readers. McArthur had strong ties to the Oregon Historical Society, but until 1954, the Society had no publishing operation other than its Quarterly. In 1944 McArthur turned to Binfords \& Mort as the logical publisher for a mass-market expanded second edition. Binfords \& Mort was more than happy to add this important reference work to its list. Generally, Peter Binford preferred to purchase entire copyrights. The company did this for Charles Carey's two-volume General History of Oregon; Katharine Judson's Early Days in Old Oregon; Eva Emery Dye's Conquest and McLoughlin and Old Oregon; Edmond S. Meany's Vancouver's Discovery of Puget Sound; and Hector Chevigny's histories of Alaska. These books were reprinted over and over again, and remained a part of the company's permanent catalog. This intelligent publishing strategy showed how well the Binfords knew their audience. Most of these books had not been best sellers for their original publishers, but by marketing the books to schools and selling

\footnotetext{
${ }^{10}$ Lewis A. McArthur, Oregon Geographic Names, 6th ed. (Portland: Oregon Historical Society, 1992), 338.
} 
them as a part of "Pacific Northwest" sections in local stores like J.K. Gill and Meier and Frank, they became substantial moneymakers. ${ }^{11}$

The Binfords also supported and published numerous new and important historical texts. Although not the most important, one of the best selling historical texts for the company was Phillip H. Parrish's Before the Covered Wagon. This book outlined the history of European exploration of the Pacific Northwest and was written for the general reader. As a result, the book was added to the libraries of many schools.

Binfords \& Mort issued a number of historical works that were less popular, but have stood the test of time as important reference works in their particular area. Alfred Powers' History of Oregon Literature utilized first-hand accounts by Oregon authors, publishers, and readers, and primary sources to provide an exhaustive accounting of Oregon literature up to 1930. Powers' book had such an impact on Oregonian editors that, rather than giving it a typical review, the paper's editor wrote a two-column editorial that claimed that state of Oregon would be permanently in debt to Powers for his "tremendous" efforts. ${ }^{12}$

A similarly important reference was History of Oregon Newspapers (1939) by George Turnbull, of the University of Oregon's journalism department. For twenty-five years Turnbull researched every newspaper in every town in Oregon. ${ }^{13}$ The resulting book has remained the standard reference work on the topic. Binfords \& Mort published

\footnotetext{
${ }^{11}$ All of these books went into multiple printings, and since the publisher did not have to pay for editing it is safe to assume that they were key to the financial success of Binfords \& Mort.

12 Oregonian, November 12,1935, p. 8.

${ }^{13}$ Ibid., December 2, 1939, p. 6.
} 
two other books by Turnbull about history of journalism in Oregon including, An Oregon Editor's Battle for Freedom of the Press (1952) and An Oregon Crusader (1955).

In their quest to find historians and books about the Pacific Northwest that merited publication, the Binfords stumbled onto a gold mine in the form of the Oregon Writers Project, a Great Depression era program funder under the umbrella of the Works Projects Administration (WPA). The Oregon Writers Project was started in 1935 under the direction of T.J. Edmonds and in close cooperation with the Oregon State Library. ${ }^{14}$ Over the course of six years, the Oregon Writers Project (OWP) coordinated the compilation of two books that were a part of the National Guidebook Series, including a general guide for the entire state of Oregon and a guide dedicated to the Mount Hood recreation area. The OWP also initiated the compilation of a state encyclopedia, a state almanac, and a large collection of short essays on subjects ranging from agricultural practices to county histories. ${ }^{15}$

Many of the staff writers and administrators of the OWP were consultants, editors, and previous authors for Binfords \& Mort. Alfred Powers, the Binfords primary editorial consultant and one of its most celebrated authors, served as the State Director of Writing for the OWP. ${ }^{16}$ Harriet C. Long, the State Librarian and one of the Binfords' primary consultants prior to initiating their publishing program, served as the official

\footnotetext{
${ }^{14}$ WPA Collection, Oregon State Library, Salem, OR; and Tom Nash, "Federal Writers' Project in Oregon," Oregon Encyclopedia, www.oregonencyclopedia.org/entry/view/federal_writers_project_in_oregon.

${ }^{15}$ For a comprehensive listing of Oregon Writers Project publications see Jeutonne P. Brewer, The Federal Writers' Project: A Bibliography (Metuchen, NJ: Scarecrow Press, 1994). The Oregon State Library holds the definitive collection of these works, both published and unpublished.

${ }^{16}$ WPA Collection, Series 2, Correspondence, Oregon State Library, Salem, OR.
} 
State sponsor for many of the OWP writing projects. ${ }^{17}$ Howard McKinley Corning, a Metropolitan Publishing Company author, worked as a research editor for a number of the writing projects. These relationships placed Binfords \& Mort in a favorable position to take advantage of this massive amount of funded research and writing.

The first printing project that Powers was able to procure for the Metropolitan Press was quite possibly the finest work of printing ever produced by the company. In 1936, in anticipation of the dedication of the WPA-constructed Timberline Lodge, Powers designed and edited a text about the construction of the lodge. Mt. Hood Timberline Lodge: The Realization of a Community Vision Made Possible by the Works Progress Administration was written by Claire Warner Churchill, a member of the Oregon Writers' Project. The folio was printed in a limited edition of thirty-two numbered copies, which included hand tinted photographs by Claude Palmer, Ray Atkeson, and George Henderson. It appears that the WPA provided the supplies and the labor for the hand-colored plates, and Metropolitan printed the book for free. The colophon claims the book was printed by Metropolitan "as a contribution to community development, because of their interest as citizens in the Mt. Hood recreation project." It appears that copies of the book were given to the Roosevelt delegation at the dedication of Timberline, and to individuals associated with the WPA project. ${ }^{18}$

In 1940 the extensive work on the Oregon guidebook was concluding. At the urging of Powers and Corning, Binfords \& Mort put in a proposal to the WPA to publish

\footnotetext{
${ }^{17}$ Howard McKinley Corning, Dictionary of Oregon History (Portland, OR: Binfords \& Mort, 1956), foreword; and WPA Collection, Oregon State Library, Salem, OR.

${ }^{18}$ There are six known copies of this work in academic libraries: Eastern Oregon University, Multnomah County Library, Reed College, Southern Oregon University, University of Oregon, and Oregon Historical Society.
} 
Oregon's guidebook, as well as others guidebooks for states across the West. The federal government provided guidelines for format so that books were uniform, but the WPA was interested in spreading the benefits of these publications to as many publishers as possible. This placed local publishers in a favorable position in the eyes of federal administrators. The contract for Idaho's guidebook, written by Vardis Fisher, was awarded to the Caxton Printers of Caldwell, Idaho, in 1937. The Idaho guide was the first to be published, but unfortunately a Caxton warehouse fire burned most of the print run. ${ }^{19}$ The influence of OWP administrators like Powers, helped Binfords \& Mort gain the contracts for the Oregon, Nevada, Washington, and Provo, Utah, guidebooks.

These contracts sustained Binfords \& Mort during the 1940s. The publishing company did not have to fund the extensive research and writing for the works, nor did it have to pay for advertising and distribution. The WPA arranged for a New York book distributor to advertise and place the books in retail outlets across the country. ${ }^{20}$ Additionally, the local writers project staffs conducted extensive publicity campaigns. In Oregon, the OWP designed a traveling exhibit of photos and objects relating to the guidebook, as well as promotional materials that were sent to bookstores, libraries, and schools throughout the state. ${ }^{21}$ Fortunately for Binfords \& Mort, the Oregon book in particular was a huge success. Stewart Holbrook described the book as a "bang-up

\footnotetext{
${ }^{19}$ Marc S. Selvaggio, The American Guide Series: Works by the Federal Writers' Project (Berkeley, CA: Schoyer's Antiquarian Books, 1990); and The American Guide Series: State Territorial Guides Prepared by WPA Writers' Program (Washington: 1944), Www.senate.gov/reference/resources/pdf/WPAStateGuides.pdf.

${ }^{20}$ WPA Collection, Series 2, American Guide Series, Book Reviews, Oregon State Library, Salem, OR; and The Oregon Voter, June 8, 1940, 18.

${ }^{21}$ WPA Collection, Series 2, American Guide Series, Book Reviews, Oregon State Library, Salem, OR; and exhibit photos, WPA Collection, Series 2, American Guide Series, Book Reviews, Oregon State Library, Salem, OR.
} 
performance of credit both to the state and the WPA staff." ${ }^{22}$ Binfords \& Mort reprinted the Oregon guidebook repeatedly, and eventually revised the book for an updated edition in 1951. The most recent revised edition of the work was issued in 1974.

The other major Binfords publication to have its origins in the OWP was the Dictionary of Oregon History. As state guidebooks across the country began to conclude, the WPA considered initiating a program to compile state "encyclopedia fact books." The WPA issued guidelines for the compilation of these books, and in 1939 the OWP began compiling information. ${ }^{23}$ In 1940 Harriet C. Long signed a contract on behalf of the State Library with Binfords \& Mort for the publication of the encyclopedia, which was to be titled Dictionary of Oregon History. Before the manuscript was finalized, the WPA was shut down, and the United States entered World War II. Over the next fifteen years, Howard McKinley Corning, the research editor for the project, continued to expand and revise the text, and finally, in 1956, Binfords \& Mort published the work. Although the Dictionary of Oregon History did not benefit from the assistance of the WPA in publication and distribution, it did generate extensive library sales and was re-issued in 1989.

The final benefit that Binfords \& Mort reaped from the WPA was the use of unpublished historical surveys of Oregon's counties that were copyright free according to WPA guidelines and freely available through the Oregon State Library. ${ }^{24}$ From the 1950s through the 1970s, Binfords \& Mort published a series of Oregon county histories that

\footnotetext{
${ }^{22}$ Stewart Holbrook, "A State of Contrasts," review of Oregon: End of the Trail in New York Herald Tribune Books, September 22, 1940, 14.

${ }^{23}$ WPA Collection, Series 3, Dictionary of Oregon History, Box 109, Oregon State Library, Salem, OR; and Corning, Dictionary of Oregon History, foreword.

${ }^{24}$ WPA Collection, Oregon State Library, Salem, OR.
} 
incorporated information from these studies. Many of these books possessed first-hand accounts from early settlers and their families; they still serve as valuable primary source materials. Counties covered in these books were Coos, Curry, Jefferson, Clatsop, Tillamook, Harney, Morrow, Wheeler, and Yamhill.

A third area of focus for Binfords \& Mort was the publication of children's literature. Both educators and parents felt a strong need to teach children about the legacy of the Oregon pioneers, which meant there was a ready supply of local children's authors and a growing number of school libraries to purchase the books. Binfords \& Mort could look to Caldwell, Idaho, for an example of how the publication of children's books could be profitable. In 1925 the Caxton Printers began printing school texts and juvenile literature as one of their primary revenue streams. ${ }^{25}$

Alfred Powers was the initial catalyst for Peter Binford's interest in publishing juvenile books. In the company's first year, Metropolitan published Powers' collection of stories, Marooned in Crater Lake. Three years after the publication of Marooned in Crater Lake, the Inland Empire Council of Teachers of English issued a mimeographed guide to Pacific Northwest books for children. ${ }^{26}$ The guide, which included summaries and evaluations of each book, was received with surprising enthusiasm by educators and librarians across the Pacific Northwest. ${ }^{27}$ Because of this demand, the Council expanded its scope and solicited reviewers from Idaho, Montana, Oregon, and Washington for the

\footnotetext{
${ }^{25}$ Leo W. York, "The Caxton Printers Ltd. Of Caldwell, Idaho: A Study in Regional Publishing" (MS thesis, Florida State University, 1956), 10.

${ }^{26}$ Inland Empire Council of Teachers, Northwest Books: Report of the Committee on Books of the Inland Empire Council of Teachers of English, August 1933 (Missoula, MT: H. G. Merriam, 1933).

${ }^{27}$ Inland Empire Council of Teachers, Northwest Books: Report of the Committee of Books of the Inland Empire Council of Teachers of English (Portland, OR: Binfords \& Mort, 1942).
} 
preparation of a book-length version of the guide, which was eventually published by Binfords \& Mort in 1942. The creation of the Council's guide and the ensuing demand reinforced Binfords \& Mort's decision to make children's books and easy-to-read history texts an important part of their publishing program. In the 1942 edition of the Council's Northwest Books report, the project director, Rufus A. Coleman, provided a special note of thanks to Binfords \& Mort for their role in providing quality books for school libraries.

From 1930 to 1935, Binfords \& Mort published only a few books specifically for children. The most noteworthy were four juvenile novels from the Oregon Wilderness Series, by Elizabeth Lambert Wood. Wood was born in 1872, and was the daughter of Joseph Hamilton Lambert, a white settler who had settled in the area of Milwaukee, Oregon. ${ }^{28}$ As a teen, Elizabeth Lambert began writing stories and poetry for local publications, including Abigail Scott Duniway's women's rights paper, New Northwest. ${ }^{29}$ She married a Portland medical doctor, William Lee Wood, and spent much of her time writing for local literary magazines like The Pacific Monthly. ${ }^{30}$ Her son Lambert died in Europe during World War I, and shortly after her daughter in-law died and left behind two young sons. ${ }^{31}$ Tragedy continued to follow Elizabeth Wood. Her husband passed away in 1923, and she raised both of her grandsons while moving between her two homes in Oracle, Arizona, and Long Beach, Washington. ${ }^{32}$ While she was raising the boys, Wood began writing fiction stories about children living in the Oregon wilderness. Silver House of Klone Chuck (1931), The Trail of the Bear (1933), Cougar Pass (1933), and

\footnotetext{
${ }^{28}$ Oregonian, February 15, 1962, p. 8.

${ }^{29}$ Alfred Powers, History of Oregon Literature (Portland, OR: Binfords \& Mort, 1935), 693-4.

${ }^{30}$ Oregonian, March 27, 1910, p. 10; Ibid., July 17, 1923, p. 17.

${ }^{31}$ Ibid., November 15, 1944, p. 7.

${ }^{32}$ Ibid., July 17, 1923, p. 17.
} 
Wolves of the Illahee (1934) were all adventure tales set in the Oregon Cascades that involved a brother and sister's interactions with nature and animals. The author had developed a fascination with the healing powers of the wilderness in the wake of so much personal tragedy. In addition to children's literature, Elizabeth Wood co-wrote an adult novel, Mansions in the Cascades (Macmillan, 1936), with another Oregon author, Anne Shannon Monroe. The storyline of Mansions in the Cascades closely followed Wood's own story, with a medical doctor and his wife moving to the high Cascades to help the husband's failing health. ${ }^{33}$ Although largely forgotten today, Elizabeth Lambert Wood was described in her own lifetime as "one of the best known and most popular members of the Oregon literary group that is forging to the front." ${ }^{34}$

Although Alfred Powers had not written children's books after his initial offering of Marooned in Crater Lake, the juvenile audience remained at the forefront of his thoughts. In 1940 he started a quarterly children's magazine called the Junior Historical Journal, specifically targeted for eighth grade students studying local history in Oregon, Washington, Idaho, Montana, Nevada, British Columbia, and Alaska. Each issue contained a mix of historical articles, historical fiction, poetry, and illustrations. The magazine was not a Binfords \& Mort publication, but it was clearly printed by the company and made extensive use of the company's illustrations and excerpts from works that they had previously published. Peter Binford gave permission for Powers to use these works, and in return Powers helped cultivate new a new group of children's authors and illustrators that would become authors for Binfords \& Mort. Of particular importance was

\footnotetext{
${ }^{33}$ Anne Shannon Monroe and Elizabeth Lambert Wood, Mansions in the Cascades (New York: Macmillan, 1936).

${ }^{34}$ Oregonian, December 21, 1931, p. 2.
} 
Powers' hiring of the Portland artist Colista Dowling. Dowling was a leader in the Portland Women's Club, and a student and promoter of Oregon literature. ${ }^{35}$ After studying art at Drexel University and Columbia University, Dowling returned to Portland and began a career as a commercial illustrator. Some of her earliest jobs were for the Pacific Monthly, through which Alfred Powers and Peter Binford became familiar with her ability to illustrate Oregon literature. Dowling's illustrations were present in almost all of the issues of Powers' Junior Historical Journal, and they would eventually be used for a number of books published by Binfords \& Mort. Although Dowling's illustrations for Binfords were never flashy, they allowed the company to build a stock of children's books that were illustrated and appealing to school librarians as well as young readers. It was also beneficial to Binfords that as a leader of the Portland Women's Club, Dowling had strong ties to women throughout the state of Oregon.

In 1941 Binfords \& Mort published Paul Bunyan, The Work Giant, an illustrated book for early readers by Ida Virginia Turney. Paul Bunyan had become popular in 1925 when the young Oregon writer, James Stevens, wrote one of the first serious attempts to collect and evaluate Paul Bunyan lore. ${ }^{36}$ Published by Knopf in New York, Stevens' Paul Bunyan received critical acclaim from East coast critics and became a best seller in the Pacific Northwest. The publication of Turney's book, and its sequel, Paul Bunyan in the Army (1942), written by Thomas Binford while he was serving overseas during World

\footnotetext{
${ }^{35}$ Ginny Allen and Jody Klevit, Oregon Painters: The First Hundred Years (1859-1959) (Portland, OR: Oregon Historical Society Press, 1999), 145; Oregonian, October 20, 1968, p. 107; Ibid., September 6, 1925, p. Magazine 1; Ibid., April 29, 1933, p. 10; Ibid., October 31, 1921, p. 9.

${ }^{36}$ James Stevens, Paul Bunyan (New York, NY: A.A. Knopf, 1925); and James Maguire, James Stevens, Western Writers Series no. 165 (Boise, ID: Boise State University, 2005).
} 
War II, were obvious attempts to cash in on this popularity. ${ }^{37}$ Stevens seemed to appreciate the attention given to Paul Bunyan by the Binfords. During the 1940s, he became a close friend of the Binford family, and even wrote his own children's book for Binfords \& Mort, Tree Treasure, A Conservation Story (1950). ${ }^{38}$

By 1960 Binfords \& Mort had a sales list of over fifty juvenile titles. Some of these titles, like the Paul Bunyan books, ran into numerous printings and editions and sold thousands of copies over generations. None of the books were spectacular in the quality of their illustrations or their writing, but over the years they found their way into numerous Oregon libraries and homes, and achieved their intended goal of teaching Oregon history and lore to at least three generations of Oregonians.

Publishing works of natural history, history, and children's literature about the Pacific Northwest made good business sense for Binfords \& Mort. There were few competitors for these segments of the publishing market. Fiction was a different matter. Publishers across the United States were eager to find novelists that could tell stories rich in local color. This meant that some of Oregon's best fiction writers had already established relationships with larger publishers like Harpers, Morrow, Doubleday, and Macmillan. Because of this competition, Binfords \& Mort focused their energies on reissues of novels that were out of print, and authors that had been unable to sell their manuscripts to other publishers.

\footnotetext{
${ }^{37}$ John Rogers Inkslinger [pseudonym for Thomas Binford] and Bethene Miller, Paul Bunyan in the Army (Portland, OR: Binfords \& Mort, 1942).

${ }^{38}$ The close relationship between Stevens and the Binfords can be inferred from the books Stevens allowed Binfords \& Mort to publish after he had achieved national popularity. It can also be established by an inscription in the author's copy of James Stevens, Big Jim Turner: A Novel (Garden City, NY: Doubleday, 1948). The inscription reads, "For Janet and Tom Binford, dear friends of ours, fellow book-lovers and Northwest lovers, and this inscribed in a high and glowing mood before their friends on the evening of Friday, October 21, 1949, Jim and Theresa Stevens."
} 
Ultimately, Oregon readers responded favorably to the fiction issued by Binfords \& Mort. The quality of the writing was less important than stories that incorporated firsthand knowledge of Oregon. Prior to the 1930s, much of the fiction about the Pacific Northwest conformed to a writing structure best suited to the reading pattern and preferences of Eastern audiences. Numerous authors penned accounts of Oregon without any firsthand knowledge of the region. Among these lesser-known fictional accounts of Oregon published in the East were titles like The Indian Bucanier or, The Trapper's Daughter: A Romance of Oregon (Boston: F. Gleason, 1847) and The Squaw Spy, or, The Rangers of the Lava-beds (New York: Beadle and Adams, 1873). ${ }^{39}$

Other writers, even those from the Pacific Northwest, were dependent on Eastern editors and publishers to guarantee the circulation of their works. Eva Emery Dye, one of Oregon's most widely read female authors, was published by the large firm of A.C. McClurg in Chicago. Dye relied extensively on plot lines and themes from the works of Henry Wadsworth Longfellow, Sir Walter Scott, and Washington Irving, all of which were familiar and popular with eastern audiences. ${ }^{40} \mathrm{~A}$ handful of other Oregon authors found publishers outside of Oregon, including Sarah Winnemucca Hopkins (Cupples,

\footnotetext{
${ }^{39}$ Other nineteenth century fiction titles listed under the subject heading "Oregon" in the WorldCat database include: Ann S. Stephens, Esther: A Story of the Oregon Trail (London: Beadle and Company, 1864); Henry L. Boone, Trail Dog; or, The Wild Voyageurs of the Columbia River (New York, NY: DeWitt, 1874); J. F. C. Adams, Oregon Sol; or, Nick Whiffles's Boy Spy (Cleveland, OH: Westbrook, 1878); T. C. Harbaugh, Dandy Jack, or, The Outlaw of the Oregon Trail (Cleveland. OH: Westbrook, 1878); R.M. Ballantyne, Twice Bought: A Tale of the Oregon Gold Fields (London: Nisbet, 1880); Prentiss Ingraham, The Adventurous Life of Captain Jack (John W. Crawford), the Border Boy (New York, NY: Beadle and Adams, 1883); Roger Starbuck, Kentucky Ben, the Long Rifle of the Cascades, or, The Boy Trappers of Oregon (New York, NY: Beadle and Adams, 1888); Thomas Edwards, Daring Donald McKay, or, The Last War-trail of the Modocs (Erie, PA: Herald Printing, 1889); Hezekiah Butterworth, The Log School House on the Columbia a Tale of the Pioneers of the Great Northwest (New York, NY: D. Appleton, 1890); Louis Banks, An Oregon Boyhood (Boston, MA: Lee and Shepard, 1898).

${ }^{40}$ Sheri Bartlett Browne, Eva Emery Dye: Romance With the West (Corvallis, OR: Oregon State University Press, 2004), 57-9.
} 
Upham of Boston), H.L. Davis (Harpers of New York), James Stevens (Knopf and

Doubleday of New York), Charles Erskine Scott Wood (Vanguard of New York), and

Samuel L. Simpson (Lippincott of New York). Most of these writers were exceptional in their quality and subject matter, and it is likely that many Pacific Northwest authors went unpublished during the period from 1850 to 1930.

Under the guidance of Alfred Powers, Binfords \& Mort took a much more tolerant view of regional language and the use of regional landscapes than eastern publishers. ${ }^{41}$ This view is evident just by looking at the books Binfords published in 1930, its first year as a publisher. The first was Paul Hosmer's Now We're Loggin', a collection of logging tales and jokes, all written in a vernacular unique to the Pacific Northwest forests. Stewart Holbrook, a prominent early twentieth century historian, journalist, and proponent of Pacific Northwest literature, praised Now We're Loggin', noting,

Mr. Hosmer is no academic gentleman writing in an amused and detached prose about strange freaks known as lumberjacks. Hardly. He knows his timber and the men who cut it. ... In this book you will read of the real, sweating, swearing snuff-chewing fellows who live and work in the logging camps and sawmills of the Pacific Northwest. ${ }^{42}$

Finding quality fiction was a constant challenge, but Binford's managed to achieve occasional successes with the publication of adult fiction. Most notable was the company's previously discussed discovery of Genevieve (1932), an unpublished work by the late Frederick Homer Balch. Balch was one of the few native Oregonians who

\footnotetext{
${ }^{41}$ Based on an examination of books edited by Powers; news clippings and biographical materials relating to Powers in the Alfred Powers Papers, unprocessed collection, University of Oregon, Eugene, OR; and the discussion of Powers in Leona Ayres, "The History of Binfords and Mort, a Regional Publishing Company, in Portland, Oregon with Critical Annotations of Its Juvenile Books in Print in December, 1954” (MLS Thesis, University of Washington, 1955), 33-35.

${ }^{42}$ Paul Hosmer, Now We're Loggin' (Portland, OR: Metropolitan Press, 1930), preface.
} 
successfully drew on local lore to tell a compelling story attractive to a major Eastern publisher. Balch may have been the only Oregon writer of fiction to have a monument in his honor as early as the 1930s. ${ }^{43}$ The work for which Balch achieved fame was Bridge of the Gods, the only book published during his lifetime. Issued in 1890 by A.C. McClurg of Chicago, Bridge of the Gods wove together local native folklore with a missionary story. ${ }^{44}$ Balch was conscious of the importance of remaining authentic to his region in terms of prose style, setting, and story. He wrote, “To make Oregon as famous as Scott made Scotland; to make the Cascades as widely known as the Highlands; the Santiam like the Ayer of Tweed; to make the Willamette the background for romance full of passion and grandeur, grew more and more into the one central ambition of my life." ${ }^{45}$ Finding a publisher for Bridge of the Gods was no small feat. According to Alfred Powers, Bridge of the Gods was "rejected by practically all the leading publishers doing business in 1890." ${ }^{\prime 46}$ A.C. McClurg took a chance on the book, knowing that other works by unknown Oregon authors had sold well. The book was not an immediate bestseller, but it sold well enough to merit a special illustrated edition by L. Maynard Dixon. By the time of the 1904 World's Fair in Portland, Balch had built up quite a following, and, at the fair, Bridge of the Gods was performed as a live drama. The book was reprinted

\footnotetext{
${ }^{43}$ Oregonian, June 12, 1932, p. 47.

${ }^{44}$ Brian Booth and Glen Love, eds., Davis Country: H. L. Davis's Northwest (Corvallis, OR: Oregon State University Press, 2009), 11-12. Booth and Love claim that Bridge of the Gods is an example of the negative influence of evangelicalism on the development of Pacific Northwest literature, a claim that not entirely accurate. While the book obviously tells a religious story, it also incorporates local vernacular and native American tradition. Additionally, the book stood out from its contemporaries in terms of its local and national popularity.

${ }^{45}$ Balch, Genevieve, xiv.

${ }^{46}$ Ibid.
} 
numerous times throughout the twentieth century. By the beginning of the twenty-first century it had gone through over one hundred printings. ${ }^{47}$

Balch was of particular interest to the Binfords, since he was a legendary figure in Klickitat County, Washington, where the Binfords had grown up. In 1931, forty-one years after Balch's death, Alfred Powers, working as editor for Binfords, gained permission from Balch's sister, Gertrude Balch Ingalls, to publish Balch's nearly completed Genevieve: A Tale of Oregon. ${ }^{48}$ This book was an important publication for Binfords because by 1932 Balch was well known among Oregonians, and like Bridge of the Gods, Genevieve combined pioneer and Native American themes, both popular to Binfords' readers. Upon its release, the Oregonian review of Genevieve claimed that thousands of Oregonians had read and wept over Bridge of the Gods, and that Genevieve would have a comparable impact. ${ }^{49}$ Genevieve never went through as many editions as Bridge of the Gods, but it was an early success for Binfords \& Mort that added to the mythology of the Native American in the untamed wilds of Oregon.

In 1938 Binfords purchased the publication rights for Bridge of the Gods and continued to capitalize on Balch's popularity. In many ways, Balch's writings served as a model of the ideal piece of regional fiction. It combined Native American lore with the pioneer and missionary stories, themes that had been successful in nineteenth century works like Irving's Astoria and Joaquin Miller's Life Amongst the Modocs, and that continued to be successful for twentieth century authors like Ernest Haycox and H.L.

\footnotetext{
${ }^{47}$ Based on an examination of records for Bridge of the Gods in the WorldCat First Search database, http://firstsearch.oclc.org.

${ }^{48}$ Balch, Genevieve, introduction; Frederic Homer Balch, Memaloose (Portland, OR: Privately Printed by Myron Rickets \& Thomas Binford, 1934), introduction.

${ }^{49}$ Oregonian, December 18, 1932, p. 61.
} 
Davis. Judging by the number of re-issues and an evaluation of sales catalogs, Balch was one of Binford's best sellers.

Another Pacific Northwest author who had achieved a modest level of acclaim outside the region was Archie Binns. Binns had grown up in Washington, but relocated to New York after going to school at Stanford. Binns published a number of novels about the Northwest, including Lightship (Reynal and Hitchcock, 1934) and Mighty Mountain (Scribner, 1940). Lightship was Binns' first novel and upon its publication the Oregonian reviewer Webster Jones praised it effusively, writing, "Genius which comes seldom in the world of letters is discernible in this first novel by Archie Binns." ${ }^{50}$ As Binfords \& Mort sought to add more regional fiction to its booklist, it made inquiries about acquiring the rights to these two works. Both publishers believed they had maximized their sales of the two books and sold printing rights to Binfords \& Mort. Scribner's even sold the original printing plates. ${ }^{51}$ In both cases the books became good sellers for Binfords \& Mort, and as a result, most Pacific Northwest readers think of Binns as a Binfords \& Mort author. One rarely sees first editions of his books, but the Binfords \& Mort versions were reprinted numerous times and are widely available. Perhaps in appreciation for Peter Binford's willingness to keep his books in print, Binns went on to provide other books, including Northwest Gateway: The Story of the Port of Seattle (1941), exclusively for Binfords.

Whether through the purchase of copyright for previously published works or through the discovery of new authors, Binfords \& Mort's efforts in promoting regional

\footnotetext{
${ }^{50}$ Ibid., September 23, 1934, p. 53.

${ }^{51}$ Ibid., November 19, 1951, p. 15.
} 
fiction gradually led to the formation a body of work that helped shape both selfperceptions and external perceptions of the region. Literary critics from around the country, such as Joseph Henry Jackson (San Francisco Chronicle), Harry Hansen (Chicago Daily News), and H.L. Mencken (Baltimore Sun and American Mercury), praised Binfords \& Mort's efforts in promoting quality regional fiction. ${ }^{52}$ By 1960 the company had published a number of authors that literary scholars now consider synonymous with early twentieth century Pacific Northwest fiction, including Balch, Binns, Alice Greve, Sheba Hargreaves, Nard Jones, and James Stevens. ${ }^{53}$ Although not all of their books were best sellers, generally speaking the company was successful in selecting interesting Oregon fiction that was appealing to local readers.

From its first year as a publisher, Binfords \& Mort issued volumes of Oregon poetry. Poetry was always a popular form of literary expression for Oregonians. The regional literary lore and tradition in the Pacific Northwest prior to the twentieth century was mostly based on poetry. The first "book" printed in the Oregon territory, Margaret Jewett Bailey's The Grains (1854) was a work that combined verse and prose.

Additionally, some of Oregon's earliest authors to garner national acclaim were poets, which included Joaquin Miller, Charles Erskine Scott Wood, and Hazel Hall. ${ }^{54}$

In 1935 Ethel Romig Fuller, a Portland poet who would later be named Oregon's second Poet Laureate (1957-1965), described Oregon’s affinity for verse, writing, “A region with such glamorous physical geography and a heritage so highly intellectual and

\footnotetext{
52 Courtland Matthews, "Binfords \& Mort: A Publishing Dream Come True," Sunday Oregonian, December 28, 1947, 3.

53 These authors are described in Booth and Love, eds., Davis Country, 16.

${ }^{54}$ Joaquin Miller's (1837-1913) first two collections of poetry were published in Oregon (1868, 1869). In following years Miller's poetry collections became bestsellers on the East Coast and in Europe.
} 
spiritual breeds a race of poets." ${ }^{, 55}$ Fuller proceeded to describe her view of the development of poetry in Oregon, claiming that sometime around 1920 poetry writing became immensely popular in the state. She wrote:

Then out of a clear sky, an epidemic of verse-writing swept over Oregon: simultaneously in parts of the state remote from each other, persons from all walks of life, irrespective of age, began versifying - housewives, businessmen, high school and college students and their instructors, a doughboy of the World War, a florist, a wistful-eyed young widow, a Norwegian immigrant girl, the burr of her native land still on her tongue, a physician's wife in the eastern Oregon desert, an itinerant blacksmith and his wife, and an assistant county assessor. ${ }^{56}$

One might argue with Fuller's attribution of this poetic explosion to Oregon's geography and the intellectual superiority of its settlers, however, there is ample evidence that Fuller's observation of the popularity of the poetry movement was legitimate. In 1928 the University of Oregon added poetry to its curriculum with the hiring of Ernest Moll, a future Binfords \& Mort author. ${ }^{57}$ Oregon's major newspapers, including the Oregonian, The Oregon Journal, and the weekly Spectator, all added poetry columns during the 1920s. ${ }^{58}$ Although short-lived, the Northwest Poetry Society was founded in 1924 and sponsored a regular schedule of poetry readings around the state. ${ }^{59}$

Despite poetry's increasing popularity, few Oregon poets could find publishers willing to print their writings in book form. Ernst Hofer, a Portland philanthropist, worked to solve this problem in 1923 by sinking a "small fortune" into a poetry magazine titled The Lariat.$^{60}$ Unfortunately, this magazine was a poor publishing outlet for many

\footnotetext{
55 Oregon Poets (New York: Henry Harrison, 1935), [4].

${ }^{56}$ Ibid.

${ }^{57}$ Henry D. Sheldon, History of the University of Oregon (Portland: Binfords \& Mort, 1940), 242; and Oregonian, January 1, 1929, p. 32; and Ibid., December 31, 1933, p. 43.

58 Oregon Poets, [4].

${ }^{59}$ Oregonian, March 4, 1924, p. 4.

${ }^{60}$ Oregon Poets, [5].
} 
poets who did not like Hofer's political, philosophical, and moral stances. He was adamantly opposed to modernist poetry and he claimed that American writers had "gone crabwise in expressions of literary culture as a by-product of modernity in education." ${ }^{61}$ Hofer preferred highly stylized Victorian pastoral verse, which he sometimes paired with religious texts taken from the Christian Science Monitor..$^{62}$ The magazine only lasted five years and was criticized as naive by eastern critics for its focus on "wholesome" verse. ${ }^{63}$

Following the collapse of The Lariat, Oregon poets again found themselves without a viable publisher. This was particularly problematic for the handful of poets accomplished enough to have produced book-length collections. A few of the poets found a willing publisher in the small Caxton Press of Caldwell, Idaho, while others, like Hazel Hall, were accepted by major eastern publishers. Most Oregon poets were left with the local newspaper poetry column as their only possibility for publication. As the Binfords considered the viability of publishing Oregon books, undoubtedly the local popularity of poetry and the knowledge of Caxton's successes played an important role in convincing them that issuing poetry could help a regional publishing operation succeed.

Once the decision was made to publish poetry, Binfords \& Mort issued numerous titles and became key to building an Oregon poetic tradition and the state's literary lore. Over the next thirty years, the Binfords published at least one book of poetry a year, and in many years they published as many as three. The Metropolitan Publishing Company's inaugural poetry publication was Howard McKinley Corning's Mountain in the Sky

\footnotetext{
${ }^{61}$ Rolf Swenson, “Oregon's 'Poetry Landslide': Col. E. Hofer and the Lariat” Oregon Historical Quarterly 99 (1998), 19.

${ }^{62}$ Ibid., 28.

${ }^{63}$ Oregonian, March 04, 1924, p. 4; Booth and Love, eds. Davis Country, 13; "How to Get Into the Lariat," The Lariat, 6 (1925): 318.
} 
(1931), which the Oregonian's review described as a collection "grounded in a sturdy craftsmanship..." and "sounding an authentic note in western letters." ${ }^{64}$ The reviewer proceeded to write that the poem titled, "Joaquin Miller Crosses the Mountains" was "one of the finest ballads to come out of the Oregon country." ${ }^{65}$ Part of the broad appeal of Corning's poetry was its connection to specific Oregon landmarks like Mt. Hood and historical figures like Joaquin Miller.

Corning was important for the Binfords for reasons other than the quality and sales of his poetry, and well connected within the Oregon poetry community. He was active in the Northwest Poetry Society and its successor the Verseweavers, and maintained connections with aspiring writers, amateur writers, and some of Oregon's most widely read poets, including H.L. Davis and Hazel Hall. ${ }^{66}$ Through Corning's connections, the Binfords forged strong relationships with numerous Oregon poets, including Ben Hur Lampman and Ethel Romig Fuller, two future Oregon poet laureates. Some of the poetry collections published by the Binfords over the years included Dean Collins' White-Crown Singing; Ada Hastings Hedges' Desert Poems; Willis Eberman's Lines to be Left in the Earth and The Pioneers and other Poems; Chester Anders Fee's Rimes O' Round-up; Ethel Romig Fuller's Kitchen Sonnets and Skylines; George Gatlin's Some Must Wander; George Charles Kastner, Riders from the West; Ben Hur Lampman's At the End of the Car Line and How Could I be Forgetting?; Blanche Lofton's Mazama and Wecoma; Edwin T. Reed's The Bells of Long Ago; Ralph K. Storey's Linfield Floss

\footnotetext{
${ }^{64}$ Oregonian, March 29, 1931, magazine p. 7.

${ }^{65}$ Ibid.

${ }^{66}$ Howard McKinley Corning, "All the Words on the Pages, I: H.L. Davis," Oregon Historical Quarterly 73 (1972): 293-331.
} 
and Fiber; Clark Wood's Wood Chips; Elizabeth Yates's Wind Carvings; Sydney

Gorham Babson's Tahiti Holiday and Others, Poems; and Mary Alethea Woodward's Songs of the Soul.

A tangible by-product of Binfords poetry publications was the naming of two State Poet Laureates in the 1950s. In 1921, Edwin Markham, a poet of international fame residing in New York, was named Oregon's first poet laureate by virtue of his being born in Oregon in 1847. Alfred Powers wrote about Markham's popularity in the state of Oregon, saying,

Edwin Markham is not in the true sense an Oregon poet. Some citizens of the state have dramatically claimed him at various times, and he seems to have been pleased the claim was made, particularly that in 1921 it was made to the extent of crowning him poet Laureate. His poems have not been about Oregon, and he left the state permanently at the age of five, his Oregon City birth and residence up to that age having a limited chance to influence him. ${ }^{67}$

Despite Markham's tenuous connection to Oregon, state officials conferred the ceremonial Laureate title on him. They were happy to have the opportunity to associate themselves, however tenuously, with respected American poets. This honor was an anomaly, and it was thirty years before another laureate would be named, and not surprisingly the next poet laureates were Binfords \& Mort authors.

In February of 1951, the Press Club of Oregon, a professional association of newspaper writers and publishers, began to lobby the Oregon State Legislature to name Bun Hur Lampman as Poet Laureate.$^{68}$ Lampman had begun to gain statewide attention as a writer in 1916 when he was hired as an editorialist for the Oregonian. ${ }^{69}$ In addition to

${ }^{67}$ Powers, History of Oregon Literature, 333.

${ }^{68}$ Oregonian, February 10, 1951, p. 1.

${ }^{69}$ Powers, History of Oregon Literature, 655. 
publishing a novel titled Here Comes Somebody (1935), a short book on printing called The Tramp Printer (1934), and a work of non-fiction about fishing called The Coming of the Pond Fishes (1946), Binfords \& Mort issued two Lampman poetry collections: How Could I be Forgetting? (1933) and At the End of the Car Line (1942), both of which were issued in numerous printings. On February 17, 1951, the Legislature approved Lampman's appointment as Poet Laureate, making him the first poet living within the state to hold the position. ${ }^{70}$

While Binfords could not take sole responsibility for Lampman's popularity, his nomination probably would not have been possible without the added publicity and notoriety that came from his poetry collections issued by Binfords \& Mort. Many locals were familiar with Lampman's writings through the Oregonian, but his book publications brought him a much wider readership, including that of U.S. Supreme Court Justice William O. Douglas, who was one of many to write the Oregon State Legislature in support of Lampman's nomination as Poet Laureate. ${ }^{71}$ At the time of his nomination, Lampman had only one book published outside of the state, and without a local publisher like Binfords, it is unlikely that Lampman would have been able to see his works put into print.

Like Lampman, Ethel Romig Fuller benefited from her visibility as poet editor for the Oregonian, when state officials considered her for poet laureate. Fuller, however, never would have attained the poetry editor position if it were not for the publicity she received as an author for Binfords \& Mort. The company wrote letters on Fuller's behalf

\footnotetext{
${ }^{70}$ Oregonian, February 17, 1951, p. 1.

${ }^{71}$ Ibid., February 16, 1951, p. 22.
} 
and sponsored poetry readings to promote her work. After Fuller was honored as Poet Laureate, Binfords \& Mort used her title in their advertising of her books. ${ }^{72}$ Although poetry never sold as well as history, fiction, or children's literature for Binfords \& Mort, it is clear that the company played a significant role in the development of the poetry scene in Oregon. Certainly Binfords \& Mort was important in allowing Oregon poetry to exist as a viable art form by providing a valuable lifeline to the growing numbers of enthusiasts described by Ethel Romig Fuller.

By focusing on five key genres (natural history, history, juvenile literature, fiction, and poetry) of Oregon literature, Binfords \& Mort were able to build a successful publishing business. All five genres shared a focus on authentic local stories, regional vernacular, and nostalgia. Within two short years of publishing, Binfords \& Mort's influence on the local literary scene was evident. In a letter to the Oregonian of December 7, 1932, Gertrude L. Babcock described being at the J.K. Gill poetry corner and running into multiple local authors and seeing numerous local books, many of which were authored by Metropolitan writers. She wrote, "I returned to the group by the fire, but my mind wandered backwards to that lone cabin standing on the banks of the river, amid the absolute silence of the forest, and I could hardly believe that the people had accomplished so much in the few years. Yet I had their works before my eyes, and by their fruits you shall know them." 73

By 1936 the influence of the Binfords was even more pronounced. In an article titled “Oregon Becomes Active Center for Writers," Eleanor Allen claimed, without

\footnotetext{
${ }^{72}$ Ethel Romig Fuller Papers, 1883-1965, Ax 650, University of Oregon Special Collections, Eugene, OR. ${ }^{73}$ Oregonian, December 7, 1932, p. 6.
} 
citing her source, that Portland ranked third in numbers of nationally known writers

behind only New York and Hollywood..$^{74}$ Allen wrote,

Many Oregon novelists have drawn heavily upon our rich heritage of folk lore. From that shadowy time before the white man penetrated this northwest, through the adventurous times of the fur traders, trappers and the pioneers, our past has unrolled in a dramatic pageant of courage, tragedy and vision from the vivid recreation by our writers. ${ }^{75}$

National critics like H.L. Mencken praised Binfords \& Mort's books for possessing regional flavor, even though none of the books became national best sellers of the caliber of Davis's Honey in Horn. But national success was not a prerequisite for Binfords \& Mort's local success. Peter Binford and Alfred Powers had created a business model built on appealing to local tastes, and indirectly they had helped shape a whole generation of Oregon literature.

\footnotetext{
${ }^{74}$ Ibid., March 29, 1936, p. 58.

${ }^{75}$ Ibid.; Allen singled out a number of Metropolitan books as worthy of special attention. These included: The Bells of Helmus, Happy Endings, Silver House of Clone Chuck, Trail of the Bear, Wolves of the Illahe, Men of Champoeg, The Journal of Theodore Talbot, History of Oregon (Carey), Before the Covered Wagon, The White-Headed Eagle, Joab Powell, Homespun Missionary, John McLoughlin, Patriarch of the Northwest, History of Oregon Literature, The Cabin at the Trail's End, Giants and Ghosts of Central Europe, Oregon Geographic Names, Northwest Nature Trails, How Could I Be Forgetting?, BirdWatching in the Pacific Northwest, Wild Flowers of the Pacific Coast, Roadside Flowers of the Pacific Coast, Friendly Firs, By Scarlet Torch and Blade, Kitchen Sonnets, White Peaks and Green, Desert Poems, Mountain in the Sky, Campus Sonnets, Native Moments, Rimes o' Round-up, High Country, Cathlamet on the Columbia, Slave Wives of the Nehalem, and Legend of the Klickitats.
} 


\section{CONCLUSION: A PUBLISHER'S LEGACY}

Understanding the full significance of regional publishing in Oregon and the role of Binfords \& Mort requires a brief look at how Oregon and the Pacific Northwest changed as a result of regional publications. Binfords \& Mort, Alfred Powers, and the large number of authors published by Binfords \& Mort not only shaped the Oregon literary sensibility, but they also affected the development of vital cultural institutions in Oregon. The most visible of these legacies were Binfords \& Mort's influence on regional historical scholarship, the development of regional studies in secondary education, the growth of a vibrant local literary community, and the development of Portland's bookselling industry.

Through its publication of history reference books, Binfords \& Mort helped usher in a flourishing period of historical scholarship. Binfords \& Mort was the primary beneficiary of scholarship facilitated by reference works like Dictionary of Oregon History, Oregon Geographic Names, and History of Oregon Literature, but local historical societies and the Oregon Historical Society also benefited. The content of these reference works focused the energies of development staffs and facilitated growth in literary collections at the University of Oregon and historical collections at OHS. As these collections were being built, Binfords \& Mort reference books provided an easy way for staff to identify potential areas for collection development. For example, literary collections were saved and added to holdings at Oregon Historical Society and the University of Oregon because the names of unknown or forgotten authors could be 
identified from the bibliographic entries in Powers' History of Oregon Literature. This expedited the research process and indirectly led to the Oregon Historical Society Press.

Reference books and historical narratives published by Binfords \& Mort also affected Oregon's secondary education system. For years, teachers, administrators, and community leaders had called for an Oregon history component in the curriculum of secondary schools. In 1922 the State Board of Education approved a requirement for students to be tested on their knowledge of Oregon history in the eighth grade. ${ }^{1}$

Individual school districts were left to teach Oregon history as they saw appropriate. With a limited number of studies of Oregon history, implementation of the policy was inconsistent. One year after the Binfords began publishing, the State of Oregon began making textbook selections to support its testing requirements. The textbook selected to assist in teaching Oregon history for 1931 was Robert Carlton Clark's A History of Oregon (Chicago: Row, Peterson and Company, 1925). ${ }^{2}$ Although A History of Oregon was not a Binfords \& Mort book, the State Textbook Commission's recommendation prompted the State Librarian, Harriet C. Long, to make her own recommendations to teachers, which included three books published during Binfords \& Mort's first two years. ${ }^{3}$ While it is clear that there was a desire to teach Oregon history, civics, and literature in the secondary school system prior to the establishment of Binfords \& Mort, the books issued by Binfords \& Mort became a fundamental support of the program. From 1931 to 1960, the years when Binfords \& Mort was most active and its books were receiving rave reviews from the State Librarian and educators across the Pacific Northwest, the

\footnotetext{
${ }^{1}$ Oregonian, October 8, 1922, p. 8.

${ }^{2}$ C. A. Howard, "Textbook Adoption" Oregon Education Journal 5 (January, 1931): 21.

${ }^{3}$ Harriet C. Long, “Oregon State Library” Oregon Education Journal 5 (June, 1931): 13.
} 
curriculum saw rapid expansion. Book reviews and feature articles during the 1930s in the Oregon Education Journal showed the enthusiasm with which new books about Oregon were received. In addition to reference books and standard histories, Binfords \& Mort published guides to the Oregon and Washington state governments, providing students with a practical understanding of local state governments. ${ }^{4}$ To this day, school libraries across the state hold Binfords \& Mort books that were published during the thirties and forties.

Literary societies and advocacy organizations formed throughout Oregon after Binfords \& Mort began making large quantities of Oregon literature available to the public. Some of the organizations that were active in reading regional authors included the Northwest Poetry Society (1924), the Alpha Literary Society (1930), the Meadowbrook Literary Society (1932), the Catholic Book Club (1932), Gill's Juvenile Book Club (1938), Portland Verseweavers Poetry Society (1936), and the Oregon Poetry Association (1956). ${ }^{5}$ Ethel Romig Fuller and Howard McKinley Corning, both Binfords \& Mort authors, were active in the Northwest Poetry Society and the Portland Verseweavers. ${ }^{6}$ Many of these organizations would have existed without Binfords \& Mort, but the publisher's books made these groups more regional in nature and resulted in more readers familiar with Oregon literature.

\footnotetext{
${ }^{4}$ Charles Childs, The Oregon Legislature: A Pamphlet Describing Legislative Procedure and Commenting on the Legislative Branch of State Government; with House and Senate Rules, and Sections of the State Constitution Affecting Legislative Organization and Procedure (Portland, OR: Metropolitan Press, 1937); Harold E. Barto and Catharine Bullard, Washington: Its History, Government, Industries, and Resources: Study Guide with Exercises (Portland, OR: Binfords \& Mort, 1942); Clarence M. Cooke, Our Daily Life: Oregon Civil Government, 1946 (Portland, OR: Binfords \& Mort, 1946).

${ }^{5}$ Notices of the events and books read by the groups can be found in the Oregonian.

${ }^{6}$ Howard McKinley Corning, "All the Words on the Pages, I: H. L. Davis" Oregon Historical Quarterly 73 (1972): 296.
} 
The presence of a bookseller with established distribution networks was a prerequisite for the success of Binfords \& Mort. Portland's J.K. Gill met this need, and the relationship mutually beneficial. As the Binfords \& Mort booklist grew, J.K. Gill dedicated a part of its store to Pacific Northwest literature. It hosted readings by local authors, sponsored book clubs, and created a community of avid readers, who trusted J.K. Gill to provide them with good local literature. In turn, these book buyers made it possible for J.K. Gill and other independent booksellers to succeed in the relatively small Portland market. During the second half of the twentieth century, Portland's reputation for being a "literary" city was partially a result of the avid regional readership that developed during the 1930s and 1940s. When Gill closed its bookstore in 1991, Powell's and a number of smaller independent booksellers continued to operate healthy book businesses into the twenty-first century. ${ }^{7}$ Although the majority of books sold at the end of the twentieth century were not written by Oregon authors, the attachment to the local bookstore remained strong, and only began to erode as reading began to shift from the codex to digital media.

After assessing the cumulative impact of Binfords \& Mort, there is no doubt that the company was a critically important part of the Oregon cultural scene from the 1930s through the 1950s. Peter Binford and Alfred Powers, in particular, tapped into the enthusiasm of Oregonians for stories of the pioneer era. The result was the creation of a community of Oregon authors, the formation of an Oregon literary sensibility, and the establishment of a whole series of cultural institutions inspired by and built on the literary output of Binfords \& Mort.

${ }_{7}^{7}$ Oregonian, December 25, 1998, p. D01. 
Articulating the full importance of Binfords \& Mort is difficult because the historical record shows a highly successful company that was lauded by community leaders during its heyday, although today Binfords \& Mort is largely ignored in scholarly studies of Oregon history and literature. This neglect appears to be the result of scholars seeking and being attracted to the exceptional. In studies of Oregon's literary history during the first half of the twentieth century, writers with national followings like H. L. Davis and James Stevens have consistently drawn the attention of critics. The studies of Oregon literature highlight Davis and Stevens as examples of how Oregon writing emerged from its pioneer roots to become modern. This story, however, has never matched Oregon's actual literary output. It fails to adequately explain why there were so many other local writers and books that never met the standards of Davis and Stevens and begs the question: how should we judge the middle and low brow books published by Binfords \& Mort, many of which are focused on the pioneer experience and seem to share more in common with nineteenth century pioneer literature.

The story of Binfords \& Mort answers this question. The company's publishing output from 1930 to 1960 included over 300 titles. Most of the company's books were based on stories connected to the pioneer period. In fact, many of the titles were reprints of nineteenth century books that still resonated with Oregon readers. Based on the large quantity of these titles and their prevalence in contemporary newspaper advertisements and sales catalogs, one can conclude that a majority of Oregon writers and readers connected with the type of books published by Binfords \& Mort, and even preferred the pioneer narrative to the critically successful books by Davis and Stevens. Therefore, we 
should not view books like those published by Binfords \& Mort as anomalous and somehow disconnected from the context provided by their predecessors. Rather, they should be seen as the norm. They were updated versions of the pioneer narrative. As such, they provide a link between the nineteenth century pioneer writing and readers' tastes in the twentieth century. The novels by Davis and Stevens are the oddities that don't fit as well into this revised version of the history of Oregon literature. Stevens and Davis are more appropriately viewed in a national literary context, where they are clearly a part of the broader literary movement embodied by H. L. Mencken and contributors to The Smart Set and The American Mercury.

The tendency of Oregon literary scholars to focus on critically successful literature over popular books is just one of the reasons Binfords \& Mort has been ignored. Studies of the history of publishing in Oregon and beyond are not common because they pose a number of methodological challenges. Generally speaking, corporate publishing records are rarely made available for research. This was certainly the case with Binfords \& Mort, and it was also the case with their associate publishers like the New York publisher, William Morrow. Researchers can get around this problem by scouring contemporary newspapers and manuscript collections of authors, but this method provides an incomplete story. To write the history of publishing effectively requires a willingness and ability to examine books and artifacts and interpret their materiality. This thesis took on the challenge of studying books as artifacts, and this is a model that should be used for future projects to expand our understanding of the history of Oregon publishing. 
By utilizing the methodology described above, in addition to a revised understanding of the role of popular regional literature in Oregon as championed by Binfords \& Mort, it should be possible to begin to craft a more accurate understanding of the intellectual development of Oregon literature. There is ample evidence that Binfords $\&$ Mort shaped literary sensibilities, regional historical scholarship, secondary education, the local literary community, and Portland's bookselling industry. 


\section{UNPUBLISHED SOURCES CITED}

Alfred Powers Papers, University of Oregon, Eugene, OR.

Ben Hur Lampman Papers, University of Oregon, Eugene, OR.

Binfords \& Mort Papers, Reed College Archives, Portland, OR.

Charles Erskine Scott Wood Papers, Huntington Library, San Marino, CA.

Ethel Romig Fuller Papers, 1883-1965, Ax 650, University of Oregon Special Collections, Eugene, OR.

Frank William Baltes Papers, Mss. 1592, Oregon Historical Society, Portland, OR.

Henry H. Woodward Papers, 1885-1905, Mss. 873, Oregon Historical Society, Portland, OR.

Laura K. Phillips Revocable Living Trust Agreement, June 1, 1998, Marylhurst University, Portland, OR.

Lehman Brothers Collection, Harvard University, Cambridge, MA.

Oregon Printing Association Records, Mss. 950, Oregon Historical Society, Portland, OR.

Oregon Works Projects Administration Collection, Oregon State Library, Salem, OR.

Portland YMCA Records, Lewis \& Clark College Special Collections, Portland, OR.

Portland Woman's Club Records, Oregon Historical Society, Portland, OR.

Thomas Binford Collection, Marylhurst University Library, Portland, OR.

William Bittle Wells Papers, University of Oregon, Portland, OR.

Wood Family Papers, Lewis \& Clark College Special Collections, Portland, OR. 


\section{PRINT AND ONLINE SOURCES CITED}

Adams, W. Claude. History of Papermaking in the Pacific Northwest. Portland, OR: Binfords \& Mort, 1951.

Adams, William Lysander. "Treason, Stratagems, and Spoils.” Oregonian. February 14, 21, and March 6 and 13, 1852.

Allen, Ginny and Jody Klevit. Oregon Painters: The First Hundred Years (1859-1959). Portland, OR: Oregon Historical Society Press, 1999.

Allred, Christine Edwards. "Harper's Indians: Representing Native America in Popular Magazine Culture, 1893-1922.” Ph.D. diss., University of California, Los Angeles, 2001.

Alvord, Benjamin. “The Doctor-Killing Oregons." Harpers New Monthly Magazine 68 (1884).

The American Guide Series: State Territorial Guides Prepared by WPA Writers' Program. Washington: 1944.

www.senate.gov/reference/resources/pdf/WPAStateGuides.pdf.

Andrews, Ralph W. "Pioneering Pictorial Histories: First Twenty-five Years of Superior Publishing Company." Journal of the West. 11 (April, 1972): 367-78.

Ayres, Leona. "The History of Binfords and Mort, a Regional Publishing Company, in Portland, Oregon with Critical Annotations of Its Juvenile Books in Print in December, 1954." ML thesis, University of Washington, 1955.

Bailey, Margaret Jewett. The Grains and Passages in the Life of Ruth Rover. Edited by Evelyn Leasher and Robert J. Frank. Corvallis, OR: Oregon State University Press, 1986.

Balch, Frederic Homer. Genevieve: A Tale of Oregon. Portland, OR: Metropolitan Press, 1932.

Balch, Frederic Homer. Memaloose. Portland, OR: Privately printed by Myron Rickets \& Thomas Binford, 1934.

Ballou, Howard Malcolm. "The History of the Oregon Mission Press." The Quarterly of the Oregon Historical Society 23 (1922). 
Baltes, F.W. The Cost of Printing: A System in Practical Operation, with Forms and Books Especially Adapted to Large and Small Printing Concerns. Portland, OR: F.W. Baltes and Company, 1894.

Bancroft, Hubert Howe and [Frances Fuller Victor]. History of the Pacific States of North America. 34 vols. San Francisco: A.L. Bancroft, 1882-90.

Barto, Harold E. and Catharine Bullard. Washington: Its History, Government, Industries, and Resources: Study Guide with Exercises. Portland, OR: Binfords \& Mort. 1942.

Becker, Paula. "Fire Destroys Seven Blocks of Downtown Goldendale on May 13, 1888." HistoryLink, www.historylink.org.

Beckey, Fred. Range of Glaciers: The Exploration and Survey of the Northern Cascade Range. Portland: Oregon Historical Society, 2003.

Belknap, George. Oregon Imprints, 1845-1870. Eugene: University of Oregon, 1968.

Benguiat, Felix [Charles Erskine Scott Wood]. "On the Making of Books." Pacific Monthly (September 1911).

Benson, Lee. Turner \& Beard: American Historical Writing Reconsidered. New York: The Free Press, 1965.

Benton, Megan. Beauty and the Book: Fine Editions and Cultural Distinction in America. Yale University Press, 2000.

Billington, Ray Allen. Frederick Jackson Turner: Historian, Scholar, Teacher. New York: Oxford University Pres, 1973.

Binford, Janet, ed. Of Books \& Mortals: A Small Informal Magazine Issued Free and Occasionally 1 (January-March 1950).

Binford-Fleming, Nelia. Sketches of Early High Prairie. Portland: Binfords \& Mort, 1949.

Bingham, Edwin and Tim Barnes, eds. Wood Works: The Life and Writings of Charles Erskine Scott Wood. Corvallis: Oregon State University Press, 1997.

Bingham, Edwin R., and Glen A. Love, eds. Northwest Perspectives: Essays on the Culture of the Pacific Northwest. Eugene: University of Oregon, and Seattle: University of Washington Press, 1979.

Blumenthal, Joseph. The Printed Book in America. Boston: David R. Godine, 1977. 
Booth, Brian and Glen Love, eds. Davis Country: H.L. Davis's Northwest. Corvallis: Oregon State University Press, 2009.

Brewer, Jeutonne P. The Federal Writers' Project: A Bibliography. Metuchen, NJ: Scarecrow Press, 1994.

Broder, Douglas F. U.S. Antitrust Law and Enforcement: A Practice Introduction. New York: Oxford University Press, 2010.

Browne, Sheri Bartlett. Eva Emery Dye: Romance With the West. Corvallis: Oregon State University Press, 2004).

Burchard, Boyd. “40 Titles Later: Book House Proves Experts Wrong." The Seattle Times. March 5, 1961.

Burgess, James M. “New Books.” Oregon Education Journal 5 (October 1930): 37.

Cardwell, J.R. "The First Fruits of the Land: A Brief History of Early Horticulture in Oregon II.” Oregon Historical Quarterly 7 (1906): 151-162.

Carstenson, Vernon. “The Development and Application of Regional-Sectional Concepts, 1900-1950." In Regionalism in America. Madison: University of Wisconsin Press, 1951.

Caughey, John Walton. Hubert Howe Bancroft: Historian of the West. Berkeley, CA: University of California Press, 1946.

A Century of Oregon Poetry: From the Private Collection of Brian Booth. Portland, OR: Friends of the Aubrey Watzek Library, Lewis \& Clark College, 2004.

Chapman, C. H. "Western Personalities: The Oregonian Himself." Sunset: The Pacific Monthly 28 (1912).

Childs, Charles. The Oregon Legislature: A Pamphlet Describing Legislative Procedure and Commenting on the Legislative Branch of State Government; with House and Senate Rules, and Sections of the State Constitution Affecting Legislative Organization and Procedure. Portland: Metropolitan Press, 1937.

Clare, Warren L. “'Posers, Parasites, and Pismires': Status Rerum, by James Stevens and H.L. Davis." Pacific Northwest Quarterly 61 (Jan. 1970): 22-30.

Clark, Harry. A Venture in History: The Production, Publication, and Sale of the Works of Hubert Howe Bancroft. Berkeley, CA: University of California Press, 1973. 
Cleaver, J. D. "L. Samuel and the West Shore: Images of a Changing Pacific Northwest." Oregon Historical Quarterly 94 (1993).

Cloud, Barbara. The Business of Newspapers on the Western Frontier. Reno: University of Nevada Press 1992.

Cohen, Arthur M. The Shaping of American Higher Education: Emergence and Growth of the Contemporary System. San Francisco: Jossey-Bass, 1998.

Cooke, Clarence M. Our Daily Life: Oregon Civil Government, 1946. Portland, OR: Binfords \& Mort, 1946.

Coolidge, Calvin. “Books for Better Homes.” The Delineator 103 (August 1923): 2.

Corning, Howard McKinley “All the Words on the Pages, I: H.L. Davis.” Oregon Historical Quarterly 73 (1972): 293-331.

Corning, Howard McKinley. Dictionary of Oregon History. Portland, OR: Binfords \& Mort, 1956.

Courtland Matthews, "Binfords \& Mort: A Publishing Dream Come True." Sunday Oregonian, December 28, 1947.

Democratic Standard (Portland).

Davis, H. L. and James Stevens. Status Rerum: A Manifesto Upon the Present Condition of Northwestern Literature, Containing Several Near-libelous Uttrances, Upon Persons in the Public Eye. The Dalles: Printed Privately for the Craft, 1927.

Dee, Minnie Roof. From Oxcart to Airplane: A Biography of George H. Himes. Portland: Binfords \& Mort, 1939.

Dodds, Gordon, ed. Varieties of Hope: An Anthology of Oregon Prose. Corvallis: Oregon State University Press, 1993.

Drake, Donald. "Portland Publisher Wins National Notice in Publishing Books by Northwest Authors." Oregonian, November 19, 1951.

Douthit, Nathan. Uncertain Encounters: Indians and Whites at Peace and War in Southern Oregon, 1820s-1860s. Corvallis: Oregon State University Press, 2002.

Duniway, Abigail Scott. From the West to the West. Chicago: A.C. McClurg, 1905. 
Dupree, A. Hunter. Science in the Federal Government. Cambridge: Harvard University Press, 1957.

Ehrlichk, Roseanne. "Picturing Americans: The Regulation of Social Conduct through Images as Seen in the Beginning of Modern-Day Mass Communication in America." MA thesis, Empire State College, 2007.

Enari, Leonid. Plants of the Pacific Northwest. Portland, OR: Binfords \& Mort, 1956.

Fabian, Ann. "Amateur Authorship." In A History of the Book in America: The Industrial Book, 1840-1880, edited by Scott E. Casper. Chapel Hill: University of North Carolina Press and American Antiquarian Society, 2007.

FamilySearch.org [website]. https://www.familysearch.org/s/recordDetails/show?uri=http\%3A\%2F\%2Fpilot.famil ysearch.org\%2Frecords\%2Ftrk\%3A\%2Ffsrs\%2Frr_373818\%2Fp2\&hash=HloWXpZ gU9zB10k5M56iYku8TUc\%253D

Find A Grave [website]. http://www.findagrave.com/cgibin/fg.cgi? page $=$ gr\&GRid $=21016360$, and http://www.findagrave.com/cgi-bin/fg.cgi?page=gr\&GRid=21016382

Fisher, Vardis. The Caxton Printers in Idaho, A Short History. Cincinnati: Society of Bibliosphers, 1944.

Fitzgerald, F. Scott. The Great Gatsby New York: Scribner's, 1925.

Gaston, Joseph. Portland Oregon: Its History and Builders. Portland, S.J. Clarke, 1911.

Genealogy.com [website], http://genforum.genealogy.com/scudder/messages/1062.html.

Glass \& Prudhomme Co. Catalogues that Escape the Waste Basket. Portland, OR: Glass \& Prudhomme, ca. 1912.

Glaeser, Edward L. and Claudia Goldin, Corruption and Reform: Lessons from America's Economic History. Chicago: University of Chicago Press, 2006.

Gleanings of Fifty Years: The Sisters of the Holy Names in the Northwest, 1859-1909. Portland, OR: Glass \& Prudhomme, 1909.

Glisan, Rodney. Journal of Army Life. San Francisco: A.L. Bancroft, 1874.

Gould, Dorothy. Beyond the Shining Mountains. Portland, OR: Binfords \& Mort, 1938. 
Groce, George and David Wallace. The New York Historical Society's Dictionary of Artists in America, 1564-1860. New Haven: Yale University Press, 1957.

Haarsager, Sandra. Organized Womanhood: Cultural Politics in the Pacific Northwest 1840-1920. Norman: University of Oklahoma Press, 1997.

Hamburger, Robert. Two Rooms: The Life of Charles Erskine Scott Wood. Lincoln: University of Nebraska Press, 1998.

Hardt, Ulrich. "Ada Hastings Hedges.” In Oregon Encyclopedia, www.oregonencyclopedia.org.

Hardwick, Bonnie. "Science and Art: The Travel Writings of the Great Surveys of the American West after the Civil War," thesis, University of Pennsylvania, 1977.

Harlan, Robert D. John Henry Nash: The Biography of a Career. Berkeley: University of California Press, 1970.

Hart, James D. Fine Printing: The San Francisco Tradition. Washington, D.C.: Library of Congress, 1985.

Hayes, Jeff W. Tales of the Sierras. Portland, OR: F.W. Baltes, 1900.

Heitman, Francis B. Historical Register of the United States Army: From its Organization September 29, 1789, to September 29, 1889. Washington D.C.: National Tribune, 1890.

Hemingway, Ernest. A Farewell to Arms. New York: Scribners, 1929.

Higham, John, et al. History. New Jersey: Prentice-Hall, 1965.

Himes, George H. "History of Organization of Oregon State Agricultural Society." Oregon Historical Quarterly 8 (1907): 317-328.

Himes, George H. "History of the Press of Oregon 1839-1850." The Quarterly of the Oregon Historical Society 3 (1902): 327-370.

History of the Oregonian. Portland, OR: The Oregonian, 1947.

Hoffman, Frederick J. The Little Magazine: A History and Bibliography. Princeton, NJ: Princeton University Press, 1946.

Holbrook, Stewart. "A State of Contrasts," review of Oregon: End of the Trail in New York Herald Tribune Books, September 22, 1940. 
Hosmer, Paul. Now We're Loggin.' Portland, OR: Metropolitan Press, 1930.

"How to Get Into the Lariat." The Lariat 6 (1925): 318.

Howard, C. A. “Textbook Adoption.” Oregon Education Journal 5 (January, 1931): 21.

Iggers, Georg G. and James M. Powell, eds., Leopold von Ranke and the Shaping of the Historical Discipline. Syracuse, NY: Syracuse University Press, 1990.

In Memoriam [Stephen James McCormick]. San Francisco, CA: 1891.

Inkslinger, John Rogers [pseudonym for Thomas Binford] and Bethene Miller. Paul Bunyan in the Army. Portland, OR: Binfords \& Mort, 1942.

Inland Empire Council of Teachers. Northwest Books: Report of the Committee on Books of the Inland Empire Council of Teachers of English, August 1933. Missoula, MT: H. G. Merriam, 1933.

Inland Empire Council of Teachers. Northwest Books: Report of the Committee of Books of the Inland Empire Council of Teachers of English. Portland, OR: Binfords \& Mort, 1942.

Jagodzinski, Cecile M. "The University Press in North America: A Brief History." Journal of Scholarly Publishing 40 (2008).

Jensen, Merrill ed., Regionalism in America. Madison: University of Wisconsin Press, 1951.

Johnson, David Alan. Founding the Far West: California, Oregon, and Nevada, 18401890. Berkeley, CA: University of California Press, 1992.

Johnston, Paul Emigh. "A History of the Caxton Printers, Limited of Caldwell, Idaho." M.A. thesis, University California, Berkeley, 1956.

Kautz, August V. “Ascent of Mount Rainier,” Overland Monthly 14 (1875): 393-403.

Krieger, Leonard. Ranke: The Meaning of History. Chicago, IL: University of Chicago Press, 1977.

Larsell, Olaf. "The Development of Medical Education in the Pacific Northwest." Oregon Historical Quarterly 27 (1926): 66. 
Laugesen, Amanda. "George Himes, F.G. Young, and the Early Years of the Oregon Historical Society.” Oregon Historical Quarterly 101 (Spring 2000): 18-39.

Laugesen, Amanda. "Making Western Pasts: Historical Societies of Kansas, Wisconsin and Oregon, 1870-1920." PhD diss., Australian National University, 2000.

Lee, Alfred M. The Daily Newspaper in America: The Evolution of a Social Instrument. New York: Macmillan, 1937.

Levine, Lawrence W. Highbrow / Lowbrow: The Emergence of Cultural Hierarchy in America. Boston, MA: Harvard University Press, 1988.

Levy, Felix H. "The Federal Anit-Trust Law and the Rule of Reason." Virginia Law Review 1 (1913): 188-209.

Levy, Felix H. "Should the Sherman Law Be Revised?" Virginia Law Review 6 (October 1919): 1-19.

Lilly, Thomas. “The National Archive: 'Harper's New Monthly Magazine' And The Civic Responsibilities Of A Commercial Literary Periodical, 1850-18." American Periodicals 15 (2005): 142-162.

Lockley, Fred. History of the Columbia River Valley, from The Dalles to the Sea. Chicago: S.J. Clarke, 1928.

Long, Elizabeth. "Aflame with Culture: Reading and the Social Mission in the Nineteenth-Century White Women's Literary Club Movement." In Print in Motion: The Expansion of Publishing and Reading in the United States, 1880-1940, edited by Carl F. Kaestle and Janice Radway. Chapel Hill: University of North Carolina Press in Association with the American Antiquarian Society, 2009.

Long, Harriet C. “Oregon State Library.” Oregon Education Journal 5 (June, 1931): 13.

Love, Glen A. "Stemming the Avalanche of Tripe." Reprinted in Davis, H. L. Collected Essays and Short Stories. Moscow: University of Idaho Press, 1986.

Luey, Beth. "The Organization of the Book Publishing Industry." In The Enduring Book: Print Culture in Postwar America v. 5 A History of the Book in America, Edited by David Paul Nort, et al. Chapel Hill: University of North Carolina Press, 2009.

Lutz, Tom. Cosmopolitan Vistas: American Regionalism and Literary Value. Ithaca, NY: Cornell University Press, 2004. 
Lyman, H. S. "Teaching History: Paper Contributed by Professor H.S. Lyman, of Astoria, to Oregon Teachers' Monthly." Oregonian, November 24, 1901.

Maguire, James. James Stevens. Western Writers Series no. 165. Boise, ID: Boise State University, 2005.

Margaret J. Crane [Margaret J. Bailey] obituary. Puget Sound Weekly Courier, May 19, 1882.

Masson, Thomas L. “Domestic Bookaflage.” Independent, April 14, 1923.

Matthews, Courtland. "Binfords \& Mort: A Publishing Dream Come True.” Sunday Oregonian, December 28, 1947.

May, Pete ed. History of Klickitat County. Goldendale: Klickitat County Historical Society, 1982.

McArthur, Lewis A. Oregon Geographic Names. Sixth ed. Portland: Oregon Historical Society, 1992.

Mencken, H. L. The American Language: An Inquiry into the Development of English in the United States Supplement Two. New York: Knopf, 1948.

Merriam, H.G. "Editorial," The Frontier 8 (1927): 1.

Miller, Cincinnatus H. [Joaquin]. Joaquin, Et Al. Portland, OR: S.J. McCormick, 1869.

Miller, Cincinnatus H. [Joaquin]. Specimens. Portland, OR: George H. Himes, 1868.

Mood, Fulmer. "The Origin, Evolution, and Application of the Sectional Concept, 17501900." In Regionalism in America. Madison: University of Wisconsin Press, 1951.

Monroe, Anne Shannon and Elizabeth Lambert Wood. Mansions in the Cascades. New York: Macmillan, 1936.

Morse, Jedediah. The American Geography or, a View of the Present Situation of the United States of America. Elizabeth Town: Printed by Shepard Kollock, for the author. 1789.

Nash, Tom. "Federal Writers' Project in Oregon." Oregon Encyclopedia, http://oregonencyclopedia.org. 
National Bureau of Economic Research (NBER) Macro History Database. Wholesale price of newsprint. Series m04093a,b., http://www.nber.og/databases/macrohistory/contents/chapter04.html

Neavill, Gordon B. "Publishing in Wartime: The Modern Library Series During the Second World War." Library Trends 55.3 (2007): 583.

Nordstöm, Lars. "The Growth of Regionalism in the Early Poetry of the American Northwest." Studia Neophilogica 57 (1985): 191-201.

Northwest Books: Report of the Committee of Books of the Inland Empire Council of Teachers of English. Portland: Binfords \& Mort, 1942.

The Northwest Pacific Farmer.

Notson, Robert C. Making the Day Begin: A Story of the Oregonian. Portland: Oregonian Publishing Co., 1976.

Novick, Peter. That Noble Dream: The "Objectivity Question" and the American Historical Profession. Cambridge: Cambridge University Press, 1998.

Online Archive of California, http://www.oac.cdlib.org.

Oregana [college annual]. Eugene: University of Oregon, 1933.

Oregon Federation of Woman's Clubs. Fifty Years of Progress, 1899-1950. Portland, OR: 1950.

Oregon Historical Quarterly.

Oregon Poets. New York: Henry Harrison, 1935.

Oregon Spectator.

The Oregon Voter, 100, n. 23 (June 8, 1940): 18.

Oregonian.

Pacific Monthly.

Pattee, Fred Lewis. The First Century of American Literature, 1770-1870. NY: Cooper Square Publishers, 1935. 
Pearson, Andrea. “'Frank Leslie's Illustrated Newspaper and 'Harper's Weekly:' Innovation and Imitation in Nineteenth-Century American Pictorial Reporting." Journal of Popular Culture 23 (1990): 81-111.

Peterson, William S. The Kelmscott Press: A History of William Morris's Typographical Adventure. Berkley and Los Angeles: University of California Press, 1991.

Pettengill, S.M. Pettengill's Newspaper Directory and Advertisers' Hand-book for 1878. New York: Pettingill, 1878.

Pintarch, Paul. "Publishing from the Bottom Shelf Up." Oregonian Northwest Magazine, January 8, 1984.

Portland City Directory. Portland: S.J. McCormick, 1863-75; 1878-81; A.G. Walling, 1876-77; J.K. Gill, 1882, 1884; R.L. Polk, 1889-90.

Portland Directory for 1869: Embracing a Business and General Directory of Residents and a Directory of East Portland. Together with other Statistical Information. Portland, OR: A.G. Walling's Book and Job Office, 1869.

Portland Journal.

Powell, John W. "Physiographic Processes." In The Physiography of the United States. New York: National Geographic Society, 1896.

Powers, Alfred. "Chronicle of Western Books Published in 1941." Oregon Historical Quarterly 43 (1941): 66.

Powers, Alfred. History of Oregon Literature Portland, OR: Metropolitan Press, 1935.

Prettyman, Gib. "Harper's Weekly And The Spectacle Of Industrialization." American Periodicals 11 (2001): 24-48.

Proceedings of the Oregon Historical Society, 1898-1899.

Ransom, Will. Private Presses and Their Books. New York: R.R. Bowker, 1929.

Ronda, James P. Beyond Lewis \& Clark: The Army Explores the West. Tacoma: Washington State Historical Society, 2003.

Rota, Anthony. Apart from the Text. Pinner, Middlesex, England: Private Libraries Association; New Castle, DE: Oak Knoll Press, 1998. 
Satterfield, Archie. "Publisher Has Keen Interest in Northwest." The Seattle Times. September 8, 1968

The Saturday Review of Literature, May 9, 1936.

Schlossberg, Robert S. ed. Mergers and Acquisitions: Understanding the Antitrust Issues. Chicago, IL: ABA Section of Antitrust Law, 2004.

Schoenberg, Wilfred. Jesuit Mission Presses in the Pacific Northwest: A History and Bibliography of Imprints, 1876-1899. Portland, OR: Champoeg Press, 1957.

Scott, Harvey W. History of the Oregon Country. Cambridge: Riverside Press, 1924.

Selvaggio, Marc S. The American Guide Series: Works by the Federal Writers' Project. Berkeley, CA: Schoyer's Antiquarian Books, 1990.

Sheldon, Henry D. History of the University of Oregon. Portland: Binfords \& Mort, 1940.

Simonson, Harold P. "Pacific Northwest Literature-Its Coming of Age." Pacific Northwest Quarterly 71 (Oct. 1980): 146-51.

Skinner, Jeremy. "The United States Army and the Development of Science, 1848-1861." BA thesis, Lewis \& Clark College, 1999.

Stanard, Everett Earle. "Books by Oregon Authors Make Fine Christmas Gifts." Oregonian, December 18, 1932.

Stegner, Wallace. "Decade of Regional Publishing: Caxton Printers of Caldwell, Idaho." Publishers' Weekly 135 (March 15, 1939): 1060-1064.

Steiner, Michael. Region and Regionalism in the United States: A Source Bookfor the Humanities and Social Sciences. New York: Garland Press, 1988.

Stevens, James. Big Jim Turner: A Novel. Garden City, NY: Doubleday, 1948.

Stevens, James. Paul Bunyan. New York: A.A. Knopf, 1925.

Strong, Thomas Nelson. Cathlamet on the Columbia: Recollections of the Indian People and Short Stories of Early Pioneer Days in the Valley of the Lower Columbia River. Portland, OR: Metropolitan Press, 1930.

Swenson, Rolf. “Oregon's 'Poetry Landslide': Col. E. Hofer and the Lariat.” Oregon Historical Quarterly 99 (1998). 
Tebbel, John. A History of Book Publishing in the United States. New York: R.R. Bowker, 1981.

Thompson, Susan Otis. American Book Design and William Morris $2^{\text {nd }}$ ed. The British Library and Oak Knoll Press, 1996.

Tompson, Robert L. Wiring a Continent: The History of the Telegraph Industry in the United States, 1832-1866. Princeton, NJ: Princeton University Press, 1947.

Turnbull, George S. History of Oregon Newspapers. Portland, OR: Binfords \& Mort, 1939.

Turner, Frederick Jackson. The Frontier in American History with a Foreword by Ray Allen Billington. New York: Holt, Rinehart and Winston, 1962.

Twining, Frances Staver. Bird-Watching in the West. Portland, OR: Metropolitan Press, 1932.

United States Census Office. 7th census, 1850. Statistical View of the United States ... Being a compendium of the seventh census to which are added the results of every previous census, beginning with 1790 ... New York, Gordon and Breach Science Publishers [1970].

Venn, George. "Continuity in Northwest Literature." In Northwest Perspectives: Essays on the Culture of the Pacific Northwest edited by Edwin Bingham and Glen Love. Eugene: University of Oregon, 1979.

Venn, George. Soldier to Advocate: C.E.S. Wood's 1877 Legacy: A Soldier's Unpublished Diary, Drawings, Poetry, and letters of Alaska and the Nez Perce Conflict. La Grande, OR: Wordcraft of Oregon, 2006.

Veysey, Laurence R. The Emergence of the American University. Chicago: University of Chicago Press, 1970.

West, James L. "The Expansion of the National Book Trade System." In A History of the Book in America: Print in Motion: The Expansion of Publishing and Reading in the United States, 1880-1940, v. 4. University of North Carolina Press, 2009.

The West Shore. Portland, OR: L. Samuel, 1875-1891.

Winship, Michael. "The Rise of a National Book Trade System in the United States." In Print in Motion: The Expansion of Publishing and Reading in the United States, 1880-1940, edited by Carl Kaestle and Janice A. Radway. Chapel Hill: University of North Carolina Press with the American Antiquarian Society, 2009. 
Wood, Erskine. Life of Charles Erskine Scott Wood. Vancouver, WA: Rose Wind Press, 1991.

Woodward, Henry H. Lyrics of the Umpqua. New York: John B. Alden, 1889.

Woodward, Henry H. The Pioneer's Offering. Roseburg, OR: Ensign, 1867.

Works Progress Association. History of the Portland Woman's Club. Portland, OR: n.d.

WorldCat FirstSearch database, http://www.firstsearch.oclc.org.

Wyckoff, William and Chantell Nash. "Geographical Images of the American West: The View from Harper's Monthly, 1850-1900.” Journal of the West 1994 (33): 10-21.

York, Leo W. "The Caxton Printers Ltd. Of Caldwell, Idaho: A Study in Regional Publishing." MS thesis, Florida State University, 1956.

Zunz, Olivier. Why the American Century? University of Chicago Press, 1998. 


\section{BINFORDS \& MORT WORKS CONSULTED}

\section{$\underline{1895-1929}$}

Oregon Industrial Exposition. Official Catalogue of the Oregon Industrial Exposition at Portland, Oregon. Portland, OR: Metropolitan Printing House, 1895.

Hammond Manufacturing Company. Hammond Manufacturing Co.: Manufacturers of the Hammond Patent Stamp Mill, Ore Feeders, Stationary and Detachable Wire Rope, Tramways, and Dealers in All Kinds of Mining Machinery. Portland, OR: Hammond Manufacturing Co., Press of Metropolitan Printing House), 1896. 3rd ed.

Killingsworth, William M., ed. Oregon's Pocket Book, a Graphic, Statistical Presentation of the Wealth of Oregon. Portland, OR: Metropolitan Ptg. Co., 1899.

National Copper Mines Company. National Copper Mines Company. Portland, OR: Metropolitan Press, 1906.

Stow, Marion Cook. The Child and the Dream: A Christmas Story. Portland, OR: Metropolitan Press, 1908.

Klickitat Development League. Klickitat County, Washington. [Goldendale, Wash.?]: Klickitat County, Metropolitan Ptg. Co.), 1909.

Stow, Marion Cook. Voices of the City. Portland, OR: The Metropolitan Press, 1909.

Portland Press Club. Official Souvenir Program, Portland Press Club Presenting “A Night Off" At the Heilig Theatre: Special Features From All the Theatres of Portland, and Skits By Members and Volunteers Among Local Talent: Good Musical Selections. [Portland, OR: Metropolitan Printing Co.], 1910.

Portland Press Club. Souvenir Program of the Second Annual "Frolic" of the Portland Press Club Presenting "The Fortune Hunter” at the Heilig Theatre Monday evening, December 11, 1911. [Portland, OR: Metropolitan Printing Co.], 1911.

Cuff, Arthur John. Meat Purchasing a Science. [Portland, Or.] Metropolitan Press, 1914.

Rose City Cemetery Association, Portland, Or. Rose City Cemetery, Portland, Oregon, Nineteen Hundred and Fourteen. [Portland, OR: Metropolitan Ptg. Co.], 1914.

Acton, John H. Uncle Jack's Discovery: Sixty Short True, Strange, Interesting and Instructive Stories About Animals, Birds, Fishes, Reptiles and Insects, With a Prize Loveletter To Young America. [Portland, OR: Metropolitan Press], 1915. 
Stow, Marion Cook. Where Flows Hood River. Portland, OR: Metropolitan Press, 1917, (c) 1907.

Short, Francis Burgette. Appreciation Sermon Delivered in Wilbur Methodist Episcopal Church, Portland, Oregon ... Sunday morning, March 30, 1919. Portland, OR:

Metropolitan Press, 1919.

Wood, Lambert Alexander. Geological Sketch of the Region of Tucson, Arizona. Portland, OR: Metropolitan Press, 1920.

Youngson, William Wallace. Memoir of Bishop Matthew Simpson Hughes, D.D., LL.D. [Portland, OR: Metropolitan Press, 1920.

Owens-Adair, Bethenia. Human Sterilization: Its Social and Legislative Aspects. Portland: Metropolitan Press, 1922.

Parsons, John. Beside the Beautiful Willamette. Portland, OR: Metropolitan Press, 1924.

Hoadley, Burton James. Two Mornings. Portland, OR: Metropolitan Press, 1925.

Breck, Frank A., Mrs. To Comfort Thee, and Other Verse. [Portland, OR: Metropolitan Printing Company, 1927.

\section{$\underline{1930}$}

Corning, Howard McKinley. The Mountain in the Sky: A Book of Oregon Poems. Portland, OR: Metropolitan Press, 1930.

Hedges, Ada Hastings. Desert Poems. Portland, OR: Metropolitan Press, 1930.

Hosmer, Paul. Now We're Loggin'. Portland, OR: Metropolitan Press, 1930.

Powers, Alfred. Marooned in Crater Lake: Stories of the Skyline Trail, the Umpqua Trail, and the Old Oregon Trail. Portland, OR: Metropolitan Press, 1930. Limited myrtlewood edition and 2d edition both published in 1930.

Strong, Thomas Nelson. Cathlamet on the Columbia: Recollections of the Indian people and Short Stories of Early Pioneer Days in the Valley of the Lower Columbia River. Portland, OR: Metropolitan Press, 1930, (c)1906.

\section{1}

Euwer, Anthony. The Friendly Firs. Portland, OR: Metropolitan Press, 1931. 
Fuller, Ethel Romig. Doing Dishes. Portland, OR: Metropolitan Press, 1931. [4] p. ; 18 $\mathrm{cm}$. Poem./ Publisher's advertisement for Kitchen Sonnets (and lyrics of domesticity).

Fuller, Ethel Romig. Kitchen Sonnets (and Lyrics of Domesticity). Portland, OR: Metropolitan Press, 1931. Reprinted in 1938 and in 1956.

The Loop: (A Tale of the Oregon Country). Portland, OR: Metropolitan Press, 1931. Oregon journal edition.

Moll, Ernest. Native Moments and Other Poems. Portland, OR: Metropolitan Press, 1931.

Norton, William Bernard. Facing the Golden West. Portland, OR: Metropolitan Press, 1931.

Parrish, Philip H. Before the Covered Wagon. Portland, OR: Metropolitan Press, 1931. Reprinted in 1934

Reynolds, Edward Samuel “Tige.” Fifty Cartoons. Portland, OR: Metropolitan Press, 1931.

Talbot, Theodore. The Journals of Theodore Talbot, 1843 and 1849-52; with the Fremont expedition of 1843 and with the first military company in Oregon territory, 1849-1852. edited, with notes, by Charles H. Carey. Portland, OR: Metropolitan Press, 1931.

Twining, Frances. Birdwatching in the West. Portland, OR: Metropolitan Press, 1931.

Watt, Roberta Frye. Four Wagons West: The Story of Seattle. Portland, OR: Metropolitan Press, 1931. Reprinted in 1959.

Wood, Elizabeth Lambert. Silver House of Klone Chuck. Portland, OR: Metropolitan Press, 1931.

\section{$\underline{1932}$}

Balch, Frederic Homer. Genevieve: A Tale of Oregon. Portland, OR: Metropolitan Press, 1932.

Benner, James. Dust or Diamonds: “Domestic Tranquility.” Portland: Metropolitan Press, 1932.

Cunningham, Bessie Mothersill. In the Shadow of the Mosque of Omar. Portland, OR: Metropolitan Press, 1932. 
Dobbs, Caroline. Men of Champoeg: A Record of the Lives of the Pioneers who Founded the Oregon Government. Portland, OR: Metropolitan Press, 1932

Gilkey, J. A. The Heroes of the Yukon and Other Poems. Portland, OR: Metropolitan Press, 1932.

Gill, Harriet Markham. Highways of Oregon: With Scenes of the Oregon Country. Portland, OR: Metropolitan Press, 1932.

Gray, Albert Bartlett. Gray's Lines in Verse, a Book of Short Poems. Portland, OR: Metropolitan Press, 1932.

Johnsone, Delphene. Webs of Harmony. Portland, OR: Metropolitan Press, 1932.

Kastner, George Charles. Riders from the West. Portland, OR: Metropolitan Press, 1932.

Miller, Joaquin and Howard McKinley Corning and Alfred Powers. A Royal Highway of the World. Portland, OR: Metropolitan Press, 1932.

Newlin, Harold V. An Answer to Prohibition ... [Portland, OR: Metropolitan Press], 1932.

Sherrard, Drew. Roadside Flowers of the Pacific Northwest. Portland, OR: Metropolitan Press, 1932.

Taylor, Rosetta Eby. Poems of Oregon: And Other Verse. Portland, OR: Metropolitan Press, 1932.

Teichert, Minerva. A Romance of Old Fort Hall. Portland, OR: Metropolitan Press, 1932.

Wahl, Natalie Rice. 200, and Other Stories. Portland, OR: Metropolitan Press, 1932.

Wood, Elizabeth Lambert. The Trail of the Bear. Illustrated by Louise Hosch. Portland, OR: Metropolitan Press, 1932.

[Wood, Lambert Alexander]. His Job: Letters Written by a 22-year-old Lieutenant in the World War to his Parents and Others in Oregon. Portland, OR: Metropolitan Press, 1932.

\section{$\underline{1933}$}

Allen, Eleanor. Seeds of Earth. Portland, OR: Metropolitan Press, 1933.

Brewster, William L. William Mead Ladd of Portland, Oregon: A Biographical Sketch. [Portland, OR: Metropolitan Press], 1933. 
Bunnell, Clarence Orvel. Legends of the Klickitats: A Klickitat Version of the Story of the Bridge of the Gods. Portland, OR: Metropolitan Press, 1933. Reprinted in 1935, 1940s, and 1963.

Churchill, Claire Warner. Slave Wives of Nehalem. Portland, OR: Metropolitan Press, 1933.

Fuller, Ethel Romig. White Peaks and Green. Portland, OR: Metropolitan Press, 1933, (c)1928.

Hazen, David W. Giants and Ghosts of Central Europe. Portland, OR: The Metropolitan Press, 1933.

Ingham, Clara Cogswell. The Mascot Bears. illustrator, Colista Dowling. Portland, OR: Metropolitan Press, 1933.

La Barre, Julia. Stories of Shakespeare's Popular Comedies. Portland, OR: Metropolitan Press, 1933.

Lampman, Ben Hur. How Could I Be Forgetting? Portland, OR: Metropolitan Press, 1933. Reprinted in 1944, 1956.

Lampman, Herbert Sheldon. Northwest Nature Trails, A Natural History of Oregon and Washington. Portland, OR: Metropolitan Press, 1933.

Lively, James Madison. Science of Mind or Individual and Communal Knowledge. [Portland, OR: Metropolitan Press], 1933.

Meares, John. The Memorial of John Mears to the House of Commons respecting the capture of vessels in Nootka Sound. With an introduction and notes by Nellie B. Pipes. Portland, OR: Metropolitan Press, 1933.

Rea, Ella M. Mutiny on the Long Trail and King Chinook. Portland, OR: Metropolitan Press, 1933.

Taylor, Arthur Samuel and H. W. Gustin. A Course of Study in Oregon History for Elementary Grades. Portland, OR: Metropolitan Press, 1933.

Tobias, Ruby Weyburn. The Bargain Square. [Portland, OR: Metropolitan Press], 1933.

Wood, Elizabeth Lambert. Cougar Pass. illustrated by Louise Hosch. Portland, OR: Metropolitan Press, 1933.

$\underline{1934}$ 
Bruner, Mary Ladd Binford. Supplement to Binford Family Genealogy. Portland, OR: Metropolitan Printing, 1934.

Easton, T. S. The Secret of the Wallowa Cave. Portland, OR: Metropolitan Press, 1934.

Frye, Theodore C. Ferns of the Northwest, covering Washington, Oregon, Idaho, British Columbia, Montana, Wyoming, central and northern California. Portland, OR: Metropolitan Press, 1934.

Gatlin, George. Some Must Wander. Portland, OR: Metropolitan Press, 1934.

Haskin, Leslie L. Wild Flowers of the Pacific Coast, in which is described 332 flowers and shrubs of Washington, Oregon, Idaho, central and northern California and Alaska; 182 full-page illustrations. Portland, OR: Metropolitan Press, 1934. Reprinted in 1967.

Lampman, Ben Hur. The Tramp Printer, Sometime Journeyman of the Little Home-town Papers in Days that Come No More. Portland, OR: Metropolitan Press with the cooperation of Craftsman Syndicate, 1934.

Lespinasse, Cobie de. The Bells of Helmus. Portland, OR: The Metropolitan Press, 1934.

Miller, Marian. Happy Endings. Drawings by Ralph Lee. Portland, OR: [Metropolitan Press, 1934].

Moll, Ernest G. Campus Sonnets. Portland, OR: Metropolitan Press, 1934.

Perkins, Philip. Gettin' Licked and Other Verse. Portland, OR: Metropolitan Press, 1934.

Sperlin, Ottis Bedney. The Heart of the Skyloo. Portland, OR: Metropolitan Press, 1934.

Wood, Elizabeth Lambert. Wolves of the Illahee. Portland, OR: Metropolitan Press, 1934.

\section{5}

Bruner, Mary Ladd Binford. Supplement to Binford Family Genealogy. Portland, OR: Metropolitan Printing, 1935.

Carey, Charles. A General History of Oregon Prior to 1861 in Two Volumes. Portland, OR: Metropolitan Press, 1935-36. Reprinted in 1968 and 1971.

Carter, M. L. Verse, Pertaining Mostly to Early Days in Grand Ronde Valley. [Portland, OR: The Metropolitan Press], 1935. 
Ernst, Alice Henson. High Country: Four Plays from the Pacific Northwest. Portland, OR: Metropolitan Press, 1935.

Euwer, Anthony. By Scarlet Torch and Blade: Rhymes of Our Valley and Other Poems. Portland, OR: Metropolitan Press, 1935.

Fee, Chester Anders. Rimes O’ Round-up. Portland, OR: Metropolitan Press, 1935.

Johnson, Robert. John McLoughlin: Patriarch of the Northwest. Portland, OR: Metropolitan Press, 1935. Reissued as John McLoughlin: “Father of Oregon" by Binfords \& Mort, 1958.

Judson, Katharine Berry. Early Days in Old Oregon. Portland, OR: Metropolitan Press, 1935, (c)1919. [3d ed., $1^{\text {st }}$ Metropolitan ed.] Reprinted in 1936, 1944, and 1954.

Lampman, Ben Hur. Here Comes Somebody. Portland, OR: Metropolitan Press, 1935.

Moll, Ernest. Blue Interval: Poems of Crater Lake. Portland, OR: Metropolitan Press, 1935.

Nichols, Marie Leona Hobbs. Joab Powell: Homespun Missionary. Portland, OR: Metropolitan Press, 1935.

Powers, Alfred. History of Oregon Literature. Portland, OR: Metropolitan Press, 1935.

[Sister Mary Alicia]. The Rose of Jesus and Mary: A Life of the Foundress of the Sisters of the Holy Names of Jesus and Mary. Portland, OR: Metropolitan Press, 1935.

Skiff, Frederick Woodward. Adventures in Americana: Recollections of Forty Years Collecting Books, Furniture, China, Guns and Glass. Portland, OR: Metropolitan Press, 1935.

Spector, Ivar. Russia: A New History. Portland, OR: Metropolitan Press, 1935.

Taylor, Arthur Samuel. A Guide to the Study and Reading of the History of the Pacific Northwest. Portland, OR: Metropolitan Press, 1935.

Thomas, Edward Harper. Chinook: A History and Dictionary of the Northwest Coast Trade Jargon; the Centuries-Old Trade Language of the Indians of the Pacific. A History of Its Origin and Its Adoption and Use By the Traders, Trappers, Pioneers and Early Settlers of the Northwest Coast. Portland, OR: Metropolitan Press, 1935. Reprinted in 1970.

Viggers, Lillian. Out of the Dumps ... Portland, OR: Metropolitan Press, 1935. 


\section{$\underline{1936}$}

Churchill, Claire Warner. Mt. Hood Timberline Lodge: The realization of a community vision made possible by the Works Progress Administration. Portland, OR: Metropolitan Press, 1936.

Davis, Lewis Jay. Our Kinsmen: A Family History. Portland, OR: [The Metropolitan press], 1936.

Dye, Eve Emery. The Conquest. Portland, OR: Binfords \& Mort, c.1936. 1936 is a copyright date. The book was actually printed in 1938, which can be ascertained from the mention of Morrow on the jacket.

Gay, Theressa. Life and Letters of Mrs. Jason Lee: First Wife of Rev. Jason Lee of the Oregon Mission. Portland, OR: Metropolitan Press, 1936.

Gilkey, Helen Margaret and Garland M. Powell. Handbook of Northwest Flowering Plants. Portland, OR: Metropolitan Press, 1936. Reprinted in 1951 and 1961.

Guberlet, Muriel L. Animals of the Seashore. Portland, OR: Metropolitan Press, 1936. Reprinted in 1949 and 1962.

Peery, Wilson Kimsey. Silver Streams. Portland, OR: Metropolitan Press, 1936.

Thayer, Claudius. Poems. Salem, OR: 1936. Printed in Portland, Oregon by Metropolitan Press.

Wood, Lambert Alexander. His Job: Letters Written by a 22-year-old Lieutenant in the World War to His Parents and Others in Oregon. Portland, OR: Metropolitan press, 1936.

Workman, Rona Morris. Just Loggin.’ Portland, OR: Metropolitan Press, 1936.

\section{7}

Almack, John C. Track of the Sun. Portland, OR: The Metropolitan Press, 1937.

Bass, Sophie Frye. Pig-Tail Days in Old Seattle. Portland, OR: Metropolitan Press, 1937. Reprinted in 1950 and 1965.

Childs, Charles. The Oregon Legislature: A Pamphlet Describing Legislative Procedure and Commenting on the Legislative Branch of State Government; with House and Senate Rules, and Sections of the State Constitution Affecting Legislative Organization and Procedure. Portland, OR: Metropolitan Press, 1937. 
Hansen, Julia Butler and Dorothea Cooke Gramatky. Singing Paddles. Portland, OR: Binfords \& Mort, 1937.

Holmstrom, Frances. Western Windows. Portland, OR: Metropolitan Press, 1937.

Jones, Nard and J. Gordon Gose. West, Young Man! Portland, OR: Metropolitan Press, 1937.

McCurdy, James G. By Juan de Fuca's Strait: Pioneering Along the Northwestern Edge of the Continent. Portland, OR: Metropolitan Press, 1937.

McNeil, Fred H. Wy'east: "The Mountain”: A Chronicle of Mount Hood Known to the Indians, Who Worshipped It, As Wy'east; To The White Man, With Equal Eloquence, Simply as "The Mountain." Portland OR: The Metropolitan Press, 1937.

Moore, Wert Emmit. Home Again. Portland, Oregon: Binfords \& Mort, Publishers, successors to Metropolitan Press, December 1937.

Murphy, Celeste G. The People of the Pueblo: or, The Story of Sonoma. Portland, OR: Binfords \& Mort, 1937.

Radke, William J. Time and Space Relative to the Recorded History in the Span of Human Existence. Portland, OR: Printed by Metropolitan Printing, 1937.

Schreibeis, Charles D. Pioneer Education in the Pacific Northwest (1789-1847).

Portland, OR: Metropolitan press, 1937.

Skiff, Frederick W. Landmarks and Literature: An American Travelogue . Portland, OR: Metropolitan Press, 1937.

Spector, Ivar, translator. The Constitution of the Union of Soviet Socialist Republics Adopted By the Extraordinary VIII All-Union Congress of Soviets December 5, 1936. Portland, OR: The Metropolitan Press, 1937.

Strong, Thomas Nelson. "The Indian Village" A chapter from Cathlamet on the Columbia. Eugene, OR: Printed by Thomas Binford in an edition of 20 copies for a printing assignment at the University of Oregon, 1937.

Stephenson, Delia Morris. Dog of the Pioneer Trail. Portland, OR: Metropolitan Press, 1937.

Stevenson, Elmo Nall. Nature Rambles in the Wallowas: Sketches of the Natural History of Northeastern Oregon. Portland, OR: Metropolitan press, 1937. 
Young, Beatrice. Winds, Waves and Wonders. Portland, OR: Metropolitan press, 1937.

\section{8}

Balch, Frederic Homer. The Bridge of the Gods: A Romance of Indian Oregon. Portland: Binfords and Mort., 1938. Reprinted by Binfords in 1940-49?, 1953, and 1965.

Ballou, Robert. Early Klickitat Valley Days. Portland, OR: Metropolitan Press, 1938.

Cass, Frank Hadley. Looking Northwest. Portland, OR: Binfords \& Mort, 1938.

Cullen, Mary. Mary Cullen’s Cook Book. Portland, OR: Binfords \& Mort, 1938.

Ernst, Alice. Backstage in Xanadu, a Book of Plays. Portland, OR: Binfords \& Mort, 1938.

Faubion, Nina Lane. Some Edible Mushrooms and How to Know Them. Portland, OR: Binfords \& Mort, 1938.

Gould, Dorothy Fay. Beyond the Shining Mountains. Portland, OR: Binfords \& Mort, 1938.

Helm, Richard I. Blue Waters: An Indian Romance. Portland, OR: Binfords \& Mort, 1938.

Hyndman, James H. Modern Fly Craft. Portland, OR: Binfords \& Mort, 1938.

Inverarity, Robert Bruce. A Manual of Puppetry. Portland, OR: Binfords \& Mort, 1938

Nelson, Rhoda. Monday, Tuesday, Wednesday, of a Time when the Northwest Was Young and of How People Came to Live There. Portland, OR: Binfords \& Mort, 1938

Payne, Doris Palmer. Captain Jack, Modoc Renegade. Portland, OR: Binford \& Mort, 1938. Reprinted in 1958 and 1979.

\section{9}

Axtell, Helen. Lost Valley. Portland, OR: Metropolitan press, 1939.

Barber, Charles. Our Garden, and Glimpses Through It's Secret Gate. Portland, OR:

Binfords \& Mort, 1939. 
Cochrane, Ben H. and William Dean Coldiron. Disillusion: A Story of the Labor Struggle in the Western Wood-Working Mills. Portland, OR: Binfords \& Mort, 1939.

De Moss, Catherine Cornwall. Blue Bucket Nuggets: A Tale of Oregon's Lost Immigration. Portland, OR: Binfords \& Mort, 1939.

Dee, Minnie Roof. From Oxcart to Airplane: A Biography of George H. Himes. Portland, OR: Binfords \& Mort, 1939.

Ernest, Brother, C.S.C. Boys of the Covered Wagons. Portland, OR: Binfords \& Mort, 1939.

Frost, Roland A. Practice Dentistry and Make a Profit. Portland, OR: Binfords \& Mort, 1939.

Grannatt, Harry Silleck. The Pied Typer of Shrdlu-etaoin. Portland, OR: Binfords \& Mort, 1939.

Hanson, Rita Mohler. The Desert Road to Shani Lun: A Romance of Mongolia. Portland, OR: Binfords \& Mort, 1939.

Jennings, J. H. and William W. Blood. Dregs. Portland, OR: Binfords \& Mort, 1939.

Kirkham, Art. This and That With Art Kirkham on KOIN: Material Selected From That Used On the Radio Program of the Same Name. Portland, OR: Metropolitan Printing Co., 1939.

Munford, James Kenneth. John Ledyard: An American Marco Polo. Portland, OR:

Binfords \& Mort, 1939.

O’Brien, Margaret Mabel. Cancer Can Be Conquered: The Truth About Cancer Revealed. Portland, OR: Metropolitan press, 1939.

Robinson, Frank. Gleams Over the Horizon. Portland, OR: The Metropolitan press, 1939.

Turnbull, George Stanley. History of Oregon Newspapers. Portland, OR: Binfords \& Mort, 1939.

Villagómez Macaulay, Victoria. Spanish Travel-aide. George F. Cornwall, ed. Portland, OR: Binfords \& Mort, 1939.

Wood, Lambert Alexander. Certain Brief Conclusions from Selected Letters of Lambert Wood. Compiled by Elizabeth Lambert Wood. Portland, OR: Binfords \& Mort, 1939. 
Woodward, Mary Alethea. Songs of the Soul. Portland, OR: Binfords \& Mort, 1939.

\section{$\underline{1940}$}

Binns, Archie. Mighty Mountain. Portland, OR: Binfords and Mort, 1940.

Brand, Charles A. Horse-and-Buggy Essays. Portland, OR: Binfords \& Mort, 1940.

Chambers, Edith Lois Kerns. Genealogical Narrative: A History of the Claggett-Irvine Clans. Eugene, OR: [Portland, OR: printed by Binfords \& Mort], 1940.

Crawford, Harriet Ann. The Washington State Grange, 1889-1924: A Romance of Democracy. Portland, OR: Binfords \& Mort, 1940.

Goffin, Marie. The Trail of the Plow: An Historical Novel. Portland, OR: Binfords \& Mort, 1940.

Lance, Marion T. Steps to the Heights. Portland, OR: Metropolitan Press, 1940.

McFarland, Cara Lee. The United States National Bank of Portland, Oregon: A Historical Sketch. Portland, OR: Binfords \& Mort, 1940.

Parsons, Mable Holmes. Listener's Room. Portland: Binfords \& Mort, 1940.

Sheldon, Henry. History of University of Oregon. Portland, OR: Binfords \& Mort, 1940.

Smith, Carl. Carl Smith in Washington: Twenty-five News Years In the National Capital. Portland, OR: Binford \& Mort, 1940.

Smythe, Ray and Josephine Smythe. Stars Ahead. Portland, OR: Binfords \& Mort, 1940.

Wells, Marjorie and Essie G. Hanson. Ponds, Pools, and Puddles. Portland, OR:

Binfords, \& Mort, 1940.

Writers' Program. Nevada: A Guide to the Silver State. Portland, OR: Binfords \& Mort, 1940. Reprinted in 1957 and 1974.

Writers' Program of the Work Projects Administration in the State of Oregon. Oregon, End of the Trail. Portland: Binfords \& Mort, 1940. Reprinted in 1951 and 1974.

Young, James Philip and Elisabeth Young. Bicycle Built for Two. Portland, OR: Binfords \& Mort, 1940.

$\underline{1941}$ 
Binns, Archie. Northwest Gateway: The Story of the Port of Seattle. Portland: Binfords \& Mort, 1941.

Holmstrom, Frances. Rich Lady. Portland, OR: Binfords \& Mort, c1941.

Lomax, Alfred L. Pioneer Woolen Mills in Oregon: History of Wool and the Woolen Textile Industry in Oregon, 1811-1875. Portland, OR: Binfords \& Mort, 1941.

Ingham, Clara Cogswell. Howdy-do. Illustrated by Colista M. Murray. [Portland, OR: Metropolitan Press, 1941.

Nichols, Marie Leona Hobbs. The Mantle of Elias: The Story of Fathers Blanchet and Demers in Early Oregon. Portland, OR: Binfords \& Mort, 1941.

Our Garden Book. Portland, OR: Binfords \& Mort, 1941.

Peck, Morton Eaton. A Manual of the Higher Plants of Oregon. Portland, OR: Binfords \& Mort, 1941. Reprinted in 1961.

Pollard, Lancaster. A History of the State of Washington. Portland, OR: Binfords \& Mort, 1941. Reprinted in 1944, 1946, 1951, and 1954.

Rae, Jess Campbell. Beach Magic. Portland, OR: Binfords and Mort, 1941.

Smith, Warren D. The Scenic Treasure House of Oregon. Portland, OR: Binfords \& Mort, 1941.

Turney, Ida Virginia. Paul Bunyan, The Work Giant. Portland, OR: Binfords and Mort, 1941.

Wood, Elizabeth Lambert. There Go the Apaches. Portland, OR: Binfords \& Mort, 1941.

Workers of the Writers' Program of the Work Projects Administration in the State of Washington. Washington: A Guide to the Evergreen State. American Guide Series. Sponsored by the Washington State Historical Society. Portland, OR: Binfords \& Mort, 1941. Reprinted in 1951 and 1974.

Wright, Burnaby. Spunky. Portland, OR: Binfords \& Mort, 1941.

\section{$\underline{1942}$}

Barto, Harold E. and Catharine Bullard. Washington: Its History, Government, Industries, and Resources: Study Guide with Exercises. Portland, OR: Binfords \& Mort. 1942. 
Binford, Thomas E. and Bethene Miller. Paul Bunyan in the Army. Illustrated by Tom O’Brien. Portland, OR: Binfords \& Mort, 1942.

Chevigny, Hector. Lord of Alaska: Baranov and the Russian Adventure. Portland, OR: Binfords \& Mort, 1942. Reprinted in 1951, 1965, 1970, and 1971.

Doney, Carl G. Cheerful Yesterdays and Confident Tomorrows. Portland, OR: Binfords \& Mort, 1942.

Hazen, David. Interviewing Sinners \& Saints. Portland, OR: Binfords \& Mort, 1942.

Inland Empire Council of Teachers of English. Northwest Books, Report of the Committee on Books of the Inland Empire Council of Teachers of English, 1942.

Portland, OR: Binfords \& Mort, 1942.

Lampman, Ben Hur. At the End of the Car Line. Portland, OR: Binfords \& Mort, 1942.

Loring, Lois. The Constant Thorn. [Portland, OR: Metropolitan Press], 1942.

Matthews, James. Turn Right to Paradise. Portland, OR: Binfords \& Mort, 1942.

Meany, Edmond S. Vancouver's Discovery of Puget Sound: Portraits and Biographies of the Men Honored in the Naming of Geographic Features of Northwestern America.

Portland, OR: Binfords \& Mort, 1942, (c)1935. Reprinted in 1949, 1957

Robinson, Frank B. What This War Really Means. Moscow, ID: Psychiana Inc., 1942.

Printed by the Metropolitan Press.

Sengstacken, Agnes Ruth. Destination, West! Portland, OR: Binfords \& Mort, 1942. Reprinted in 1972.

Stroud, Mabel May. Time-Woven Tapestries. [Portland, OR]: Metropolitan Press, 1942.

Turney, Ida Virginia. Paul Bunyan Marches On. Portland, OR: Binfords \& Mort, 1942.

Wiedemann, Thomas. Cheechako into Sourdough. Portland, OR: Binfords \& Mort, 1942.

Workers of the Writers' Program of the Work Projects Administration for the State of Utah. Provo: Pioneer Mormon City. Portland, OR: Binfords \& Mort, 1942.

The United States National Bank of Portland, Oregon: A Supplement to the Historical Sketch Published in 1940, and Made Necessary by the Subsequent Purchase of the Three Banks Chronicled Herein. Portland, OR: Binfords \& Mort, 1942.. 
$\underline{1943}$

Babson, S. Gorham. Tahiti Holiday and Others: Poems. Portland, OR: Binfords \& Mort, 1943.

Chambers, Edith Lois Kerns. Genealogical Narrative: A History of Three Pioneer Families: the Kerns, Popes, and Gibsons. Eugene, OR [Portland, OR: Printed by Binfords \& Mort], 1943.

Clark, Harold Ballard. Biblical Law: Being a Text of the Statutes, Ordinances, and Judgments Established in the Holy Bible-With Many Allusions to Secular Laws:

Ancient, Medieval and Modern-Documented to the Scriptures, Judicial Decisions and Legal Literature. Portland: Binfords \& Mort, 1943. Reprinted in 1944 and 1983.

Collins, Dean. Stars of Oregon. Portland, OR: Binfords \& Mort, 1943.

Emmons, Della Gould. Sacajawea of the Shoshones. Portland, OR: Binfords \& Mort, 1943.

Gatke, Robert Moulton. Chronicles of Willamette, the Pioneer University of the West. Portland, OR: Binfords \& Mort, 1943.

MacArthur, Dougall. The Legend Whispered. Portland, OR: Binfords \& Mort, 1943.

Mayol, Lurline Bowles. The Talking Totem Pole: The Tales it Told to the Indian Children of the Northwest. Portland, OR: Binfords \& Mort, 1943. Reprinted in 2003.

\section{4}

Apperson, Alves Norwood . Genealogy of the Norwood, Hogg, Lovick, Benners and Howell, Garrett, Harrison Lines. Portland, OR: Binfords and Mort, Metropolitan Press, 1944.

Finkbeiner, John. Fruit of Field and Fireside. [Portland, OR: The Metropolitan Press], 1944.

Fisher, Anne B. Bears, Pirates and Silver Lace: Stories of Old California. Illus. by Philip Nesbitt. Portland, OR: Binfords \& Mort, 1944

Greve, Alice Wheeler. Shadow on the Plains: A Novel of the Wagon Train of 1847 and the Whitman Mission. Portland, OR: Binfords \& Mort, 1944. 
Groner, Ferd. Seeing the Future From the Past. Portland, OR: Metropolitan Printing Co., 1944.

La Londe, Leona M. Belgium Was My Home. Portland, OR: Binfords \& Mort, 1944.

McArthur, Lewis A. Oregon Geographic Names. Portland, OR: Binfords \& Mort for the Oregon Historical Society, 1944. Reprinted by Binfords in 1952 and 1965.

McArthur, Lewis A. Oregon Place Names. Illustrated by Marilyn Campbell. Portland, OR: Pub. by Binfords \& Mort for the Oregon Journal, 1944.

McKittrick, Myrtle Mason. Vallejo, Son of California. Portland, OR: Binfords \& Mort, 1944.

Morton, Arthur Silver. Sir George Simpson: Overseas Governor of the Hudson's Bay Company, a Pen Picture of a Man of Action. Portland, OR: Binfords \& Mort, 1944.

Splawn, A. J. Ka-mi-akin, Last Hero of the Yakimas. Portland, OR: Binfords \& Mort, for the Oregon Historical Society, 1944.

Thompson, Margaret. Space for Living, a Novel of the Grand Coulee and Columbia Basin. Portland, OR: Binfords \& Mort, 1944.

\section{5}

Case, Robert Ormond and Victoria Case. Last Mountains: The Story of the Cascades. Portland, OR: Binfords \& Mort, 1945. Reprinted in 1950 and 1963.

Chapple, Ann Grace. Good Fellows All: A Simple Chronicle of the White Ensign Club, Portland, Oregon, November 1942 to July 1945; Bright Threads of Red, White, and Blue in the Drab Warp and Woof of War's Dreary Weaving. Portland, OR: Metropolitan Press, 1945.

Greve, Alice Wheeler. From Out This House: Novel of Early Portland and Oregon. Portland, OR: Binfords \& Mort, 1945.

Hall, Thomas Aiton. A Child's Book of Prayers. Portland, OR: Binfords \& Mort, 1945.

Linck, James G. Paulina Preferred: A Lover of Nature Finds His Shangri-La in the High Cascades.. Portland, OR: Binfords \& Mort, 1945.

McKenny, Margaret. Abe and His Girl Friend, Amble. Portland, OR: Binfords \& Mort, 1945. 
McKenny, Margaret. Little White Pig. Portland, OR: Binfords \& Mort, 1945.

Powers, Alfred, ed. Buffalo Adventures on the Western Plains. Portland, OR: Binfords \& Mort, 1945.

Reed, Ruth Esther Shoemaker and Norma Lyon. Betsy Beaver. Portland, OR: Binfords and Mort, 1945.

Reed, Ruth Esther Shoemaker. Billy Shelley. Portland, OR: Binfords and Mort, 1945.

Villagómez Macaulay, Victoria. Spanish Travel-Aide. George F. Cornwall, ed. Portland, OR: Binfords \& Mort, 1945.

Webster, Don G. Annie. Portland, OR: Binfords and Mort, 1945.

Wood, Elizabeth Lambert. Literary Outlook in Europe: An Address Delivered Before the Oregon Literature Dinner Saturday Evening, April 9, 1932. [Portland, OR: Metropolitan press], 1945.

\section{$\underline{1946}$}

Allen, Eleanor and Esther Belle McMillan. Canvas Caravans. Portland, OR: Binfords \& Mort, 1946.

Churchill, Leila McKibben. Dick and Brownie: The Story of Boys, Dogs, and Horses. Portland, OR: Binfords \& Mort, 1946.

Collins, Dean. White Crown Singing. Portland, OR: Binfords \& Mort, 1946.

Comish, Newel Howland. Small Scale Retailing. Portland, OR: Binfords \& Mort, 1946.

Cooke, Clarence M. Our Daily Life: Oregon Civil Government, 1946. Portland, OR: Binfords \& Mort, 1946.

Crandall, Julie V. The Story of Pacific Salmon. Portland, OR: Binfords \& Mort, 1946.

Haworth, James P. Plant Magic. Portland, OR: Binfords \& Mort, 1946.

Hayden, Gwendolen and Pearl Gischler. Muslin Town: A Story About Gold Rush Days in Oregon. Portland, OR: Binfords \& Mort, 1946.

Lampman, Ben Hur. The Coming of the Pond Fishes: An Account of the Introduction of Certain Spiny-rayed Fishes, and Other Exotic Species, Into the Waters of the Lower 
Columbia River Region and the Pacific Coast States. Portland, OR: Binfords \& Mort, 1946.

Laughton, Catherine Carter. Mary Cullens' Northwest Cookbook. Portland, OR: Binfords \& Mort, 1946..

Pollard, Lancaster. Oregon and the Pacific Northwest. Portland, OR: Binfords \& Mort, 1946.

Reed, Edwin Thomas. The Bells of Long Ago, and Other Memorial Poems. Portland, OR: Binfords \& Mort, 1946.

Seaman, N. G. Indian Relics of the Pacific Northwest. Portland, OR: Binfords \& Mort, 1946. Reprinted in 1956, 1967, and 1974.

Westergaard, Jens. Synopsis Life History of Jens Christensen Westergaard. Portland, Or: Metropolitan Print. Co., 1946.

\section{7}

Case, Robert Ormond. The Empire Builders. Portland, OR: Binfords \& Mort, 1947.

Cooke, Clarence M. Our Daily Life: Oregon Civil Government, 1946. Portland, OR: Binfords \& Mort, 1947.

Corning, Howard McKinley. Willamette Landings, Ghost Towns of the River. Portland, OR: Pub. by Binfords \& Mort for the Oregon Historical Society, 1947.

Hayden, Gwendolen and Pearl Gischler. Thunder Hill. Portland, OR: Binford \& Mort, 1947.

Howard, Harry W. Salmon Fishing on Puget Sound: Salmon Fishing Contribution from the Practical Side; How, When and Where to Troll for Salmon, Spinning, Mooching, etc. Portland, OR: Binfords \& Mort, 1947.

Jones, Fred O. Grand Coulee from "Hell to Breakfast:" A Story of the Columbia River from Molten Lavas and Ice to the Grand Coulee Dam. Portland, OR: Binfords \& Mort, 1947.

Larsell, O. The Doctor in Oregon: A Medical History. Portland, OR: Pub. by Binfords \& Mort for the Oregon Historical Society, 1947.

Lespinasse, Cobie de. Four Brothers. Portland, OR: Binfords \& Mort, 1947. 
Mills, Edward Laird. Plains, Peaks, and Pioneers: Eighty Years of Methodism in Montana. Portland, OR: Binfords \& Mort, 1947.

Nesbitt, Nell Smidell. Bumpy Bison. Portland, OR: Binfords \& Mort, 1947.

Phillips, Claire and Myron B. Goldsmith. Manila Espionage. Portland, OR: Binfords \& Mort, 1947.

Purdy, Ruby Fay. The Rose City of the World: Portland, Oregon. Portland, OR: Binfords \& Mort, 1947.

\section{$\underline{1948}$}

Aumack, Thomas M. Rivers of Rain: Being a Fictional Accounting of the Adventures and Misadventures of John Rodgers Jewitt, Captive of the Indians at Friendly Cove on Nootka Island in Northwest America. Portland, OR: Binfords \& Mort, 1948.

Bond, James H. From out of the Yukon. Portland, OR: Binfords \& Mort, 1948.

Glassley, Ray Hoard. Visit the Pacific Northwest. Portland, OR: Binfords \& Mort, 1948.

Jones, Nard. Swift Flows the River. Portland, OR: Binfords \& Mort, 1948.

Keeney, Katharine. Through Life's Prisms. Portland, OR: Printed by Metropolitan Press, 1948.

McLoughlin, John. Letters of Dr. John McLoughlin Written at Fort Vancouver 18291832. Burt Brown Barker, ed. Portland: Binfords \& Mort for the Oregon Historical Society, 1948.

Montgomery, Richard Gill. Young Northwest. Portland, OR: Binfords \& Mort, 1948. 2d ed.

Murphy, Celeste G. The People of the Pueblo: or, The Story of Sonoma. Portland, OR: Binfords \& Mort, 1948, (c)1937.

Pennington, Levi Talbott. All Kinds of Weather. Portland, OR: Binfords \& Mort, 1948.

Storey, Ralph E. Linfield Floss and Fiber: A Book of Campus Verse. Portland, OR: Binfords \& Mort, 1948.

\section{9}


Beard, John W. Saddles East: Horseback Over the Old Oregon Trail. Portland, OR: Binfords \& Mort, 1949.

Becker, Ethel Anderson. Klondike '98: Hegg's Album of the 1898 Alaska Gold Rush. Portland, OR: Binfords \& Mort, 1949. Reprinted in 1958, 1967, and 1972.

Case, Robert Ormond. The Empire Builders. Portland, OR: Binfords \& Mort, 1949.

Dana, Marshall N. Their World and Ours. Portland, OR: Binfords \& Mort, 1949.

Drury, Clifford Merrill. A Tepee in His Front Yard: A Biography of H.T. Cowley, One of the Four Founders of the City of Spokane, Washington. Portland, OR: Binfords \& Mort, 1949.

Everett, Charles. Fresh Water Fishes of the Pacific Coast: Identification. Portland, OR: Binfords \& Mort, 1949.

Fleming, Nelia Binford. Sketches of Early High Prairie. Portland, OR: Binfords \& Mort, n.d. [ca. 1949]. Reprinted in 1952.

Grater, Russell K. Guide to Mount Rainier National Park. Portland, OR: Binfords \& Mort, 1949.

Linck, James G. On Being Alone. Portland, OR: Binfords \& Mort, 1949, 1945.

McClelland, John M. Longview: The Remarkable Beginnings of a Modern Western City. Portland, OR: Binfords \& Mort, 1949.

Miller, Joaquin. True Bear Stories. Portland, OR: Binfords \& Mort, 1949.

Peery, Wilson Kimsey. And There Was Salmon. Portland, OR: Binfords \& Mort, 1949.

Tobie, Harvey Elmer. No Man Like Joe: The Life and Times of Joseph L. Meek. Portland, OR: Published by Binfords \& Mort for the Oregon Historical Society, 1949.

\section{$\underline{1950}$}

Anderson, Richard. Down River: A Novel. Portland, OR: Binfords \& Mort, 1950.

Bach, Marcus. He Talked With God. Portland, OR: Metropolitan Press, 1950.

Bond, Jim. America's Number One Trophy. Portland, OR: Metropolitan Printing Co., 1950 . 
Bradner, Enos. Northwest Angling. Portland, OR: Binfords \& Mort, 1950. Reprinted 1969.

Gibbs, Jim. Pacific Graveyard: A Narrative of the Ships Lost Where the Columbia River Meets the Pacific Ocean. Portland, OR: Binfords \& Mort, 1950. Reprinted in 1964, 1973, 1992, and 1993.

Grater, Russell K. Guide to Zion, Bryce Canyon, and Cedar Breaks. Portland, OR: Binfords \& Mort, 1950.

Irving, Washington. Adventures of Captain Bonneville. Portland, OR: Binfords \& Mort, undated, c. 1950. Reprinted in 1954 and 1963.

Irving, Washington. Astoria. OR: Binfords \& Mort, 1950. Reprinted in 1951, 1967.

McMurtie, Douglas C. and George N. Belknap. Oregon Imprints: Supplement. Portland, OR: Binfords, \& Mort, 1950.

Pollock, Dean. Joseph, Chief of the Nez Perce. [Portland, OR]: Binfords \& Mort, 1950.

Smith, Charles W. and Isabel Mayhew. Charles W. Smith's Pacific Northwest Americana: A Check List of Books and Pamphlets Relating to the History of the Pacific Northwest. Portland, OR: Binfords \& Mort, 1950. Reprinted in 1981.

Spencer, Omar C. The Story of Sauvies Island. Portland, OR: Published for the Oregon Historical Society [by] Binfords \& Mort, 1950.

Stevens, James. Tree Treasure, A Conservation Story. Portland, OR: Binfords \& Mort, 1950.

Wood, Clark and Arthur L. Crookham. Wood Chips. Portland, OR: Binfords \& Mort, 1950.

Wood, Erskine. Days with Chief Joseph. Portland, OR: Binfords \& Mort for Oregon Historical Society, undated, c. 1950 Reprinted in 1951, 1953, 1970.

\section{$\underline{1951}$}

Adams, W. Claude. History of Papermaking in the Pacific Northwest. Portland, OR: Binfords \& Mort, 1951.

Brearley, Jeanette Stiles. A Vanished Hand. [Portland, OR:], Metropolitan Print., 1951. 
Brimlow, George Francis. Harney County, Oregon, and Its Range Land. Portland, OR: Binfords \& Mort, 1951.

Eberman, Willis. Lines to be Left in the Earth and Other Poems. Portland, OR: Binfords \& Mort, 1951.

Gorham, Melvin Ezell. The Culture of Individual Integrity. Portland, OR: Metropolitan Press, 1951.

Helm, Myra. Lorinda Bewley and the Whitman Massacre. Portland, OR: Metropolitan Press, 1951.

Holmstrom, Frances. Oregon Mist. [Poems] Portland, OR: Binfords \& Mort, 1951.

Jenkins, Mildred. Before the White Man Came: Pacific Northwest Indian Culture. Portland, OR: Binfords \& Mort, 1951.

McMurtrie, Douglas C. and George N. Belknap. Oregon Imprints, 1847-1870: A Supplement. Portland, OR: Binfords \& Mort, 1951.

Newell, Gordon R. Ships of the Inland Sea: The Story of the Puget Sound Steamboats. Portland: Binfords \& Mort, 1951. Reprinted in 1960.

Orcutt, Ada M. Tillamook: Land of Many Waters. Portland, OR: Binfords \& Mort, 1951.

Wood, Elizabeth Lambert. Pete French, Cattle King: A Biographical Novel. Portland, OR: Binfords \& Mort, 1951.

\section{2}

Fuller, Ethel Romig. Skylines. Portland, OR: Binfords \& Mort, 1952.

Hansen, Julia Butler and Dorthea Cooke Gramatky. Singing Paddles. Portland, OR: Binfords \& Mort, 1952, (c)1937.

Hargreaves, Sheba. The Cabin at Trail's End: A Story of Oregon. Portland, OR: Binfords \& Mort, 1952.

Hazard, Joseph T. Companion of Adventure: A Biography of Isaac Ingalls Stevens, First Governor of Washington Territory. Portland, OR: Binfords \& Mort, 1952.

Hult, Ruby El. Steamboats in the Timber. Portland, OR: Binfords \& Mort, 1952. Reprinted in 1968. 
Lofton, Blanche DeGood. Mazama \& Wecoma. Portland, OR: Binfords \& Mort, 1952.

Maddux, Percy. City on the Willamette: The Story of Portland, Oregon. Portland: Binfords \& Mort, 1952.

Peterson, Emil R. and Alfred Powers. A Century of Coos and Curry: History of Southwest Oregon. Portland, OR: Binfords \& Mort, 1952.

Sheller, Roscoe. Courage and Water, A Story of Yakima Valley's Sunnyside; A Factual Story of the Founding, Development and Growth of the Unique and Unusual City of Sunnyside, Washington, Located in the Heart of the Famous Yakima Valley. Portland, OR: Binfords \& Mort, 1952.

Truchot, Theresa. Charcoal Wagon Boy. Portland, OR: Binfords \& Mort, 1952.

Turnbull, George. An Oregon Editor's Battle for Freedom of the Press. Portland, OR: Binfords \& Mort, 1952.

Wood, Elizabeth Lambert. Face of the West. Portland, OR: Binfords \& Mort, 1952.

\section{$\underline{1953}$}

Gibbs, Jim. Tillamook Light. Portland, OR: Binfords \& Mort, 1953. Reprinted in 1979.

Glassley, Ray. Pacific Northwest Indian Wars: The Cayuse War of 1848, the Rogue River Wars of the '50s, the Yakima War, 1853-56, the Coeur d'Alene War, 1857, the Modoc War, 1873, the Nez Perce War, 1877, the Bannock War, 1878, the Sheepeater's War of 1879. Portland, OR: Binfords \& Mort, 1953. Reprinted in 1972.

Glidden, Helene. Pacific Coast Seafood Chef. Portland, OR: Binfords \& Mort, 1953.

Hulley, Clarence Charles. Alaska, 1741-1953. Portland, OR: Binfords \& Mort, 1953.

Leigh, Dorothy and Mary Raker Bartlett. World at Our Doorstep. Portland, OR: Binfords \& Mort, 1953-1957. 4 v. in 1

Levine, Raphael H. Holy Mountain: Two Paths to one God. Portland, OR: Binfords \& Mort, 1953.

McDonald, Lucile and Parker S. McAllister. Washington's Yesterdays: (Before There Was a Territory) 1775-1853. Portland, OR: Binfords \& Mort, 1953.

Wood, Elizabeth Lambert and Dean Pollock. Many Horses. Portland, OR: Binfords \& Mort, 1953. 
Yates, Elizabeth. Wind Carvings. Portland, OR: Binfords \& Mort, 1953.

\section{4}

Bede, Elbert. Fabulous Opal Whiteley: From Oregon Logging Camps to Princess in India. Portland, OR: Binfords \& Mort, 1954.

Cook, Henry W. What Life is For and the Destiny of Man. Portland, OR: Metropolitan Press, 1954.

Coons, Frederica B. The Trail to Oregon. Portland, OR: Binfords \& Mort, 1954.

Gamble, Bert. Days of Yesterday and Songs of the Palouse Country. [Portland, OR]: Metropolitan Press, 1954.

Hult, Ruby El. The Untamed Olympics: The Story of a Peninsula. Portland, OR: Binfords \& Mort, 1954. Reprinted in 1971.

McKenny, Margaret. Wildlife of the Pacific Northwest. Portland, OR: Binfords \& Mort, 1954.

Midlam, Don S. Flight of the Lucky Lady. Portland, OR: Binfords \& Mort, 1954.

Speck, Gordon. Northwest Explorations. Edited by L.K. Phillips. Portland, OR: Binfords \& Mort, 1954. Reprinted in 1970.

\section{5}

Blackerby, Alva W. and Linn Argyle Forrest. Tale of an Alaska Whale. Portland, OR: Binfords \& Mort, 1955.

Cour, Robert M. The Plywood Age: A History of the Fir Plywood Industry's First Fifty Years. Portland, OR: Binfords and Mort, 1955.

Dufresne, Frank. Alaska's Animals \& Fishes. Portland, OR: Binfords \& Mort, 1955, (c) 1946 .

Gibbs, Jim. Sentinels of the North Pacific: The Story of Pacific Coast Lighthouses and Lightships. Portland, OR: Binfords \& Mort, 1955.

Gregg, Jacob Ray. A History of the Oregon Trail, Santa Fe Trail, and Other Trails. Portland, OR: Binfords \& Mort, 1955. 
Krewson, E. A. Tioga's Pigs. Portland, OR: Binfords \& Mort, 1955.

Newell, Gordon R. SOS North Pacific: Tales of Shipwrecks off the Washington, British Columbia and Alaska Coasts. Portland, OR: Binfords \& Mort, 1955.

Speidel, William C. You Can't Eat Mount Rainier! Portland, OR: Binfords \& Mort, 1955.

Turnbull, George. An Oregon Crusader. Portland, OR: Binfords \& Mort, 1955. "An enlargement of the first edition of An Oregon Editor's Battle for Freedom of the Press (1952)."

Winthrop, Theodore. Canoe and Saddle. Portland, OR: Binfords and Mort, [undated, ca. 1955?].

Wood, Elizabeth Lambert. Long Rope. Portland, OR: Binfords \& Mort, 1955.

Ernst, Clara Woodin. Pioneers Now, and Then. Portland, OR: Metropolitan Press, 1955.

Tallent, Roxy. Spicy Trail. Portland, OR: Metropolitan Press, 1955.

\section{$\underline{1956}$}

Adams, W. Claude. History of Dentistry in Oregon. Portland: Binfords \& Mort, 1956.

Bidwell, John and Hubert Howe Bancroft [and] James Longmire. First Three Wagon Trains: To California, 1841, to Oregon, 1842, to Washington, 1853. Portland, OR:

Binfords \& Mort, 1956. Reprinted in 1959, 1961, and 1993.

Corning, Howard McKinley, ed. Dictionary of Oregon History. Portland, Binfords \& Mort, 1956. Reprinted in 1989.

Enari, Leonid. Plants of the Pacific Northwest: 663 Selected Northwest Wild Flowers, Shrubs, Trees, and Weeds. Portland, OR: Binfords \& Mort, 1956.

Fraser, Hermia Harris. Tall Brigade: True Adventures of Tom McKay, Brigade Leader for the Early Hudson's Bay Company. Portland, OR: Binfords \& Mort, 1956.

Holmes, Kenneth L., ed. Linfield's Hundred Years: A Centennial History of Linfield College, McMinnville, Oregon. Portland: Binfords \& Mort, 1956.

McKeown, Martha Ferguson. Linda's Indian Home. Portland, OR: Binfords \& Mort, 1956.

Organ, Chauncey Blish. More Than Clay. Portland, OR: Metropolitan Press, 1956. 
Wood, Elizabeth Lambert. Arizona Hoof Trails. Portland, OR: Binfords \& Mort, 1956.

\section{$\underline{1957}$}

Arntson, Herbert E. Caravan to Oregon. Portland, OR: Binfords \& Mort, 1957.

Atwood, Evangeline. Anchorage, All-American City. Portland, OR: Binfords \& Mort, 1957.

Beyler, Cecelia Mae. America Calls from Castle Walls. Portland, OR: Metropolitan Press, 1957.

Gerlinger, Irene Hazard. The Story of Roscoe Hazard. Portland, OR: Metropolitan Press, 1957.

Gibbs, Jim. Shipwrecks of the Pacific Coast. Portland, OR: Binfords \& Mort, 1957. Reprinted in 1962, 1971, and 1989.

Hamilton, James. From Wilderness to Statehood. Portland, OR: Binfords \& Mort, 1957.

Hult, Ruby El. Lost Mines and Treasures of the Pacific Northwest. Portland, OR:

Binfords \& Mort, 1957. Reprinted in 1960, 1968, and 1974.

Jefferson County Reminiscences. Portland, OR: Binfords \& Mort, 1957. Reprinted in 1998.

Mooberry, Lester C. The Gray Nineties. Portland, OR: Binford \& Mort, 1957.

Sheller, Roscoe. Ben Snipes: Northwest Cattle King. Portland, OR: Binfords \& Mort, 1957. Reprinted in 1959, 1966, and 1987.

Stoddard, Gordon. Go North, Young Man: Modern Homesteading in Alaska. Portland, OR: Binfords \& Mort, 1957.

Wood, Elizabeth Lambert. The Tragedy of the Powers Mine, an Arizona Story. Portland, OR: Binfords \& Mort, 1957.

\section{$\underline{1958}$}

Bedingfield, Nancy, comp. Oregon's 100 Years in Pictures: 1859-1959. Portland: Binfords \& Mort, 1958. 
Chevigny, Hector. Lost Empire: The Life and Adventures of Nikolai Petrovich Rezánov. Portland, OR: Binfords \& Mort, 1958. Reprinted in 1965 and 1979.

Duque, Sally. California's Father Serra. Portland, OR: Binfords \& Mort, 1958.

Fair, May. Fair Are the Petals. Portland, OR: Metropolitan Press, 1958.

Goodall, Mary. Oregon's Iron Dream: A Story of Old Oswego and the Proposed Iron Empire of the West. Portland, OR: Binfords \& Mort, 1958.

Goodsell, H. Guy. The Gallant Man. Portland, OR: Metropolitan Press, 1958.

Holbrook, Stewart H. Ethan Allen. Portland, OR: Binfords \& Mort, 1958. Reprinted 1988.

Hulley, Clarence Charles. Alaska, Past and Present. Portland, OR: Binfords \& Mort, 1958, (c)1953. First published in 1953 under title: Alaska, 1741-1953.

McDonald, Lucile. Search for the Northwest Passage. Portland, OR: Binfords \& Mort, 1958.

Miller, Emma Gene. Clatsop County, Oregon: A History. Portland, OR: Binfords \& Mort, 1958.

Netboy, Anthony. Salmon of the Pacific Northwest: Fish vs. Dams. Portland, OR: Binfords \& Mort, 1958.

\section{9}

Allen, Opal Sweazea. Narcissa Whitman: An Historical Biography. Portland, OR: Binfords \& Mort, 1959.

Annala, Hilja Ruth. Rhymes of the Valley. [Portland, OR]: Metropolitan Press, 1959.

Atterbury, Vivian Corbett. The Oregon Story. Portland, OR: Binfords \& Mort, 1959.

Ball, Thomas S. and Harriet Ball. Life of Peter Cook, Known as "Captain Cook," A Record of Crossing the Plains, From His Memoirs as Written by Himself and Daughters, and From Scrapbooks and Diaries. Portland, OR: Metropolitan Press, 1959.

Brown, R. D., and Thomas Kranidas and Faith G. Norris, eds. Oregon Signatures. Oregon: Printed by Binfords \& Mort for Oregon State College, 1959.

Caldwell, William Elmer. Family Safari. Portland, OR: Binfords \& Mort, 1959. 
Delta Kappa Gamma Society. Alpha Rho State, Oregon. Lamplighters: Leaders in Learning. Portland: Binfords \& Mort, 1959.

Eberman, Willis. The Pioneers, and Other Poems. Portland, OR: Binfords \& Mort, 1959.

McKeown, Martha Ferguson. Come to Our Salmon Feast. Portland, OR: Binfords \& Mort, 1959.

Oliver, Ethel Ross. Aleutian Boy. Portland, OR: Binfords \& Mort, 1959.

Pipes, John M. Boyhood Recollections, 1878-1891. Portland, OR: Metropolitan Press, 1959.

Russell, Ashley Howard. Siskiyou Trail. Portland, OR: Binfords \& Mort, 1959.

Strong, Emory M. Stone Age on the Columbia River. Portland, OR: Binfords \& Mort, 1959. Reprinted in 1960, 1967, and 1982.

Strong, Emory M., ed. Wakemap Mound and Nearby Sites on the Long Narrows of the Columbia River. Portland, OR: Binford \& Mort. Reprinted in 1976.

Turnbull, George. Governors of Oregon. Portland, OR: Binfords \& Mort, 1959.

\section{$\underline{1960}$}

Barber, Olive. Meet Me In Juneau. Portland, OR: Binfords \& Mort, 1960.

Hawthorne, Mont and Martha F. McKeown. The Trail Led North: Mont Hawthorne's Story. Portland, OR: Binfords \& Mort, 1960, (c)1948.

Henton, George Earle. My Henton Lineage. Portland, OR: Metropolitan Press, 1960.

Hood, Dellmann. The Tunis Hood Family: Its Lineage and Traditions. Portland, OR: Metropolitan Press, 1960.

Hult, Ruby El. Northwest Disaster: Avalanche and Fire. Portland, OR: Binfords \& Mort, 1960.

Marshall, James Stirrat and Carrie Marshall. Pacific Voyages: Selections from Scots Magazine, 1771-1808. Portland, OR: Binfords \& Mort, 1960.

McCallum, John Dennis. Scooper: Authorized Story of Scoop Conlon's Motion Picture World. Portland, OR: Binfords \& Mort, 1960. 
Shane, Ralph M. Early Explorations Through Warm Springs Reservation Area. Portland, OR: Binfords \& Mort, 1960.

\section{$\underline{1961}$}

Brooks, James E. The Oregon Almanac and Book of Facts, 1961-1962. Portland, OR: Binfords \& Mort, 1961. Reprinteed in 1962.

French, Alfred J. The Worlds Around Us: A Preliminary Survey of Apace. Portland, OR: Metropolitan Press, 1961.

Jordan, Grace Edgington. The King's Pines of Idaho: A Story of the Browns of McCall. Portland, OR: Binfords \& Mort, 1961.

McKay, Allis. They Came to a River. Portland, OR: Binfords \& Mort, 1961. Reprinted 1969.

Oliver, Herman. Gold and Cattle Country. Portland, OR: Binfords \& Mort, 1961. Reprinted in 1962 and 1967.

Pennington, Levi Talbott. Variable Winds. Portland, OR: Metropolitan Press, 1961.

\section{2}

Eberman, Willis. Dear Editor, and Other Poems. Portland, OR: Binfords \& Mort: 1962.

Ekman, Leonard C. Scenic Geology of the Pacific Northwest. Portland, OR: Binfords \& Mort, 1962. Reprinted in 1965 and 1970.

Erspamer, Alice McGill. Big Bug, the Turtle. Portland, OR: Metropolitan Press, 1962.

Gorham, Melvin Ezell. The Pagan Bible. Portland, OR: Binfords \& Mort, 1962.

Helm, Harry C. Love Singer in Paradise. Portland, OR: Metropolitan Press, 1962.

Landers, Frederick. Through Golden Windows. Portland, OR: Metropolitan Press, 1962.

Niemeier, Jean. Wild Blue Water: Cruise of the "Shield." Portland, OR: Metropolitan Press, 1962.

\section{$\underline{1963}$}


Lyman, William Denison. The Columbia River: Its History, Its Myths, Its Scenery, Its Commerce. Including a Section on the River Today. Portland, OR: Binfords \& Mort, 1963.

Scudder, Ralph E. Custer Country. Portland, OR: Binfords \& Mort, 1963.

Sheller, Roscoe. Blowsand. Portland, OR: Metropolitan Press, 1963.

\section{4}

Brogan, Phil F. East of the Cascades. Portland, OR: Binfords \& Mort, 1964. Reprinted in 1971 and 1977.

Faubion, Nina Lane. Some Edible Mushrooms and How to Cook Them. Portland, OR: Binfords \& Mort, 1964.

French, Giles. Cattle Country of Peter French. Portland, OR: Binfords \& Mort, 1964. Reprinted in 1965, 1968, and 1972.

Gibbs, Jim. Pacific Graveyard: Shipwreck Chart. Portland, OR: Binfords \& Mort, 1964. 1 map; col.; 43 x $56 \mathrm{~cm}$.

Griffin, Mary Louisa. Memorial to Father, David Chambers. Portland, OR: Metropolitan Press, 1964.

Manley, Victor John. Arthritis: Food and Arteries in Joint Disease. Portland, OR: Metropolitan Press, 1964.

Ratliff, Donald E. Map, Compass, and Campfire: [A Handbookfor the Outdoorsman]. Portland, OR: Binfords \& Mort, 1964.

\section{$\underline{1965}$}

Chevigny, Hector. Russian America: The Great Alaskan Venture, 1741-1867. Portland, OR: Binford \& Mort, 1965. Reprinted in 1979.

Flescher, Bertina. Wind Over Bracken and Sage. Portland, OR: Metropolitan Press, 1965. [

Hanson, Bruce and Robert Johnson. The Power of "Right Ideas." Portland, OR: Metropolitan Press, 1965.

Johnson, Edith Ainsworth. Wildlife at Macleay Park, and Other Sketches. Portland, OR: Metropolitan Press, 1965. 
Landers, Frederick Joseph. This Precious Earth. Portland, OR: Metropolitan Press, 1965.

Myers, Hugh H. Prisoner of War, World War II. Portland, OR: Metropolitan Press, 1965.

Price, Maurice A. and Frances Price Cook. The Pioneering Price Family. Portland, OR: Metropolitan press, 1965.

Salisbury, John. A Message for Americans. Portland, OR: Published jointly by KXL Radio and Binfords \& Mort, 1965.

Woodward, Arthur. Indian Trade Goods. Portland, OR: Binfords \& Mort for the Oregon Archaeological Society, 1965. Reprinted in 1967, 1976, and 1983.

\section{$\underline{1966}$}

French, Giles. These Things We Note. Portland, OR: Binfords \& Mort, 1966, c.1931.

Friedman, Ralph. Oregon for the Curious. Portland, OR: Pars Publishing, printed by Metropolitan, 1966. $2^{\text {nd }}$ edition.

McDonald, Lucile Saunders. Coast Country: A History of Southwest Washington. Portland, OR: Binfords \& Mort, 1966.

Mills, Paul A. Ancestors and Descendants of Henry and Mary Folger Mills. Portland, OR: Metropolitan Press, 1966.

Ward, Harriet. Gold Saga of the Umpqua: An Historical Novel of Southwestern Oregon. Portland, OR: Metropolitan Press, 1966.

\section{$\underline{1967}$}

Binns, Archie. Peter Skene Ogden: Fur Trader. Portland, OR: Binfords \& Mort, 1967.

Engel, Arnold G. Whistling in the Graveyard. Portland, OR: Metropolitan Press, 1967.

Friedman, Ralph. Tales Out of Oregon. Portland, OR: Parrs publishing, printed by Metropolitan Press, 1967.

Holmes, Kenneth L. Ewing Young: Master Trapper. Portland, OR: Published by Binfords \& Mort, for the Peter Binford Foundation, 1967. 
Lung, Edward B. and Ella Lung Martinsen. Black Sand and Gold: True Alaska-Yukon Gold-rush Story. Portland, OR: Metropolitan Press, 1967. Reprinted 1974, 1978, and 1983.

Minter, Harold. Umpqua Valley, Oregon and its Pioneers. Portland, OR: Binfords \& Mort, 1967.

Neils, Selma M. So This is Klickitat. Portland, OR: Published by Metropolitan Press for the Klickitat Woman's Club, 1967.

Pennington, Levi Talbott. Rambling Recollections of Ninety Happy Years. Portland, OR: Metropolitan Press, 1967.

Price, Henry Teller. Up the Rogue River and the First Mail Route. Portland, OR: Metropolitan Press, 1967.

Salisbury, Harold. Alaskan Songs \& Ballads. Portland, OR: Metropolitan Press, 1967.

Wood, Amos L. Beachcombing for Japanese Glass Floats. Portland, OR: Binfords \& Mort, 1967. Reprinted in 1971, 1975, and 1985.

\section{$\underline{1968}$}

Avery, Constance and Al Cembura. Luxardo Bottles: Identification and Price Guide. Portland, OR: Metropolitan Printing; distributed by Al Cembura, Berkeley, Calif., 1968.

Baker, Elizabeth. Cherokee Country. Portland, OR: Metropolitan Press, 1968.

Dryden, Cecil Pearl. Dryden's History of Washington. Portland, OR: Binfords \& Mort, 1968.

Friedman, Ralph. Northwest Passages: A Book of Travel. Portland, OR: Pars Publishing Co., printed by Metropolitan Press, 1968.

Gibbs, Jim. Shipwrecks off Juan de Fuca. Portland, OR: Binfords \& Mort, 1968.

Howe, Carrol B. Ancient Tribes of the Klamath Country. Portland, OR: Binfords \& Mort, 1968.

Jones, Nard. Marcus Whitman: The Great Command: The Story of Marcus and Narcissa Whitman and the Oregon Country Pioneers. Portland: Binfords \& Mort, 1968.

Magnuson, Richard G. Coeur d'Alene Diary: The First Ten Years of Hardrock Mining in North Idaho. Portland, OR: Metropolitan Press, 1968. Reprinted in 1983. 
McCall, Dorothy Lawson. Ranch Under the Rimrock. Portland, OR: Binfords \& Mort, 1968.

Montague, Martha Frances. Lewis and Clark College, 1867-1967. Portland, OR: Binfords \& Mort, 1968.

Niemeier, Jean Gilbreath. The Panama Story. Portland, OR: Metropolitan Press, 1968.

Pennington, Levi Talbott. Vagrant Breezes. Portland, OR: Metropolitan Press, 1968.

Scott, Frank Earl. Armageddon and You. Portland, OR: Metropolitan Press, 1968.

Slocum, Robert G. and Kenneth H. Matsen. Shoto Clay: A Description of Clay Artifacts From the Herzog Site (45-CL-4) in the Lower Columbia Region. Portland, OR: Published by Binfords \& Mort for the Oregon Archaeological Society, 1968.

Wallace, Vivian. Letters From a Retired Teacher to Today's Youth. Portland, OR: Metropolitan Press, 1968.

Yates, Herbert A. A Pioneer Project, A Story of Courage; History of the Okanogan Irrigation Project, in Okanogan County, Washington. Portland, OR: Metropolitan Press, 1968.

\section{9}

Cembura, Al and Constance Avery. Jim Beam Bottles: 1969-1970 Identification and Price Guide. [Portland, OR: Metropolitan Printing Co., 1969. Reprinted in 1970 and 1972.

Lung, Velma D. and Ella Lung Martinsen. Trail to North Star Gold, A Sequel to Black Sand and Gold, True Story of the Alaska-Klondike Gold Rush. Portland, OR:

Metropolitan Press, 1969. Reprinted in 1974.

Strong, Emory M. Stone Age In the Great Basin. Foreword by Luther S. Cressman. Portland, OR: Binfords \& Mort, 1969.

\section{$\underline{1970}$}

Flescher, Bertina. Remembering. Portland, OR: Metropolitan Press, 1970. [

Gohs, Carl. Timberline. [Portland, Or.]: Metropolitan Printing, 1970-1979? 30 p. : ill. (some col.); $22 \times 28 \mathrm{~cm}$. 
Hall, Eli S. Then to Now With Roseburg Schools, 1854-1970. Portland, OR: Metropolitan Press, 1970.

Hamilton, James. History of Montana, From Wilderness to Statehood. Portland, Binfords \& Mort, 1970. 2d ed.

Hulley, Clarence. Alaska: Past and Present. Portland, OR: Binfords \& Mort, 1970. 3d ed.

Paul, Wolfgang and Otto Stöber. Healing Earth: Moor; Its Role in Science and Medicine. Health Treasurers From an Austrian Spa: "The Neydharting Moor-Bouquet." The Quintessence of Otto Stöber's Works on Moor. Portland, OR: Metropolitan Press, 1970.

Snyder, Eugene E. Early Portland: Stump-town Triumphant; Rival Towns on the Willamette, 1831-1854. Portland, OR: Binfords \& Mort, 1970. Reprinted in 1984.

Strope, Nancy. Cattle Country Cook Book: Basic Recipes From East of the Cascades. Portland, OR: Binfords \& Mort, 1970, (c)1971. [1st ed.] x, 308 p. illus. 23 cm.

\section{1}

Allen, Alice Benson. Simon Benson: Northwest Lumber King. Portland, OR: Binfords \& Mort, 1971.

Donaldson, Ivan J. and Frederick K. Cramer. Fishwheels of the Columbia. Portland, OR: Binfords \& Mort, 1971.

French, Giles. Homesteads and Heritages: A History of Morrow County, Oregon. Portland, OR: Published by Binfords \& Mort for the Morrow County History Committee, 1971.

Hult, Ruby El. Treasure Hunting Northwest. Portland, OR: Binfords \& Mort, 1971.

Wallace, Vivian. Letters From a Retired Teacher to Today's Youth. Portland, OR: Metropolitan Press, 1971. 3d ed.

\section{$\underline{1972}$}

Caldwell, William Elmer. Travel Babble. Portland, OR: Binfords \& Mort, 1972.

Fries, U. E. From Copenhagen to Okanogan: The Autobiography of a Pioneer. Portland, OR: Binfords \& Mort, 1972. 2d ed.

McCall, Dorothy Lawson. The Copper King's Daughter: From Cape Cod to Crooked River. Portland, OR: Binfords \& Mort, 1972. 
McDonald, Lucile Saunders. Swan Among the Indians: Life of James G. Swan, 18181900; Based Upon Swan's Hitherto Unpublished Diaries and Journals. Portland, OR: Binfords \& Mort, 1972.

Scott, Frank Earl. Revelation of Mysteries. Portland, OR: Metropolitan Press, 1972.

\section{$\underline{1973}$}

Anderson, Mary A. Women In Law Enforcement: A Primer for Policewomen. Portland, OR: Metropolitan Press, 1973.

Edwards, Margaret Watt, comp. Land of the Multnomahs: Sketches and Stories of Early Oregon. Portland, OR: Binfords \& Mort, 1973.

Foundation for Oregon Research and Education; Oregon State Board of Higher Education. University Finance Study: Report and Recommendations of the University Finance Committee to the Foundation for Oregon Research and Education. Portland: Metropolitan Printing Co., 1973.

Heslep, Emma. What Manner of Love. Portland, OR: Binfords \& Mort, 1973.

Pierce, Lawrence C. and Scott S. Pengelly. The Freshman Legislator, Problems and Opportunities: A Handbook on the Oregon Legislature. Portland, OR: Binfords \& Mort, 1973. $2 \mathrm{~d}$ ed.

Rieger, Erwin. Up Is the Mountain, and Other Views. Portland, OR: Published by Binfords \& Mort for the Columbian, 1973.

Snyder, Eugene E. Skidmore's Portland: His Fountain and Its Sculptor; From Buckboards to Bustles. Portland, OR: Binfords \& Mort, 1973.

\section{4}

Barchus, Agnes. Eliza R. Barchus, the Oregon Artist, 1857-1959. Portland, OR: Binford \& Mort, 1974.

Eastman, C. Alexander. The Sin of Caring. Portland, OR: Metropolitan Press, 1974.

Garren, John. Oregon River Tours. Portland, OR: Binford \& Mort, 1974.

Grant High School (Portland, Or.). Grant's Fiftieth: A Book of Dedication. Portland, OR: Published jointly by Trade Typesetting and Metropolitan Printing Co., 1974. 
Grisewood, John. To Bed With a Book. Portland, OR: Metropolitan Press, 1974.

Keller, Paul and Jack Pement. Oregon Historical Vignettes. Portland, OR: Binfords \& Mort, 1974.

Kenaga, R. F. Impact: A Generation of Changes: [Autobiography] . Portland, OR: Metropolitan Press, 1974.

Lomax, Alfred L. Later Woolen Mills in Oregon: A History of the Woolen Mills Which Followed the Pioneer Mills. Portland, OR: Binfords \& Mort, 1974.

Mehring, Florence May Davis and Jay Lewis Davis. Genealogical Supplement to "Our Kinsmen.” Portland, Metropolitan Press, 1974.

Palmer, Pati and Susan Pletsch. Sewing Skinner ${ }^{\circledR}$ Ultrasuede ${ }^{\circledR}$ Fabric. Portland, OR: Printed by Metropolitan Printing Co., 1974. Reprinted in 1975 and 1976.

Rowe, Royle C. Geology of Our Western National Parks and Monuments. Portland, OR: Binfords \& Mort, 1974. Re-issued by Binfords in 1977.

Sauter, John and Bruce Johnson. Tillamook Indians of the Oregon Coast. Portland, OR: Binfords \& Mort, 1974.

Treacy, William and Raphael Levine and Patricia Jacobsen. Wild Branch on the Olive Tree. Portland, OR: Binford \& Mort, 1974.

Treece, J. Manley. Spiked With Laughter: [Verses]. Portland, OR: Binford \& Mort, 1974. Umphrey, Clyde Ellis. Challenge and Witness in Revelation. Portland, OR: Metropolitan Press, 1974.

$\underline{1975}$

Buckley, James L. LMC, the Impossible Dream: Development of the Lumbermens Merchandising Corporation Which Wrote a New Page In the History of Merchandising. Portland, OR: Binford \& Mort, 1975.

Eagen, Wm. The Man on the Red Horse. [s.1. : s.n.], Metropolitan Print. Co., 1975.

Fussner, F. Smith and Kathleen Buhl. Glimpses of Wheeler County's Past: An Early History of North Central Oregon. Portland, OR: Published by Binford \& Mort for the Wheeler County Historical Commission, 1975.

Huntoon, Emery. Intercept and Board. Portland, OR: Binford \& Mort, 1975. 
Keenan, Charles J. The Railroad Saga of Jeff Keenan. Portland, OR: Binford \& Mort, 1975.

Preston, Ralph N. Oregon Gold \& Gems Maps: Then \& Now. Portland, OR: Binford \& Mort, 1975. 28 maps on 6 sheets ;; 45 x $57 \mathrm{~cm}$. folded to 15 x $23 \mathrm{~cm}$. in envelope 17 x 25 $\mathrm{cm}$.

Taylor, Ronald J. and George W. Douglas. Mountain Wild Flowers of the Pacific Northwest. Portland, OR: Binford \& Mort, 1975.

Tetlow, Roger T. The Astorian: The Personal History of DeWitt Clinton Ireland, Pioneer Newspaperman, Printer, and Publisher. Portland, OR: Binford \& Mort, 1975.

Walker, Raymond B. Beside Still Waters. Portland, OR: Binford \& Mort, 1975.

Washburn, Richard Kirk. Pathways of My Thought: Philosophical Essays. Portland, OR: Binford \& Mort, 1975.

\section{$\underline{1976}$}

Hall, Betty L. Survival Education. Portland. OR: Binford \& Mort, 1976. Reprinted in 1977.

Hawkins, William John. The Grand Era of Cast-iron Architecture in Portland. Portland, OR: Binford \& Mort, 1976.

Lilly, Othelia. Leaping the Boulder Years: New and Selected Poems 1945-1975. Portland, OR: Binford \& Mort, 1976.

Marsh, Floyd R. 20 Years a Soldier of Fortune. Portland, OR: Binford \& Mort, 1976.

Palmer, Pati and Susan Pletsch. Pants for Any Body. Portland, OR: Metropolitan Printing Co., 1976.

Stoller, Ruth. Old Yamhill: The Early History of Its Towns and Cities. Portland, OR:

Binford \& Mort for Yamhill County Historical Society, 1976. vi, 106 p. : ill., maps ; 28 $\mathrm{cm}$.

White, James Seeley. Seashells of the Pacific Northwest. Portland, OR: Binford \& Mort, 1976.

$\underline{1977}$ 
Atwood, Evangeline and Robert N. DeArmond. Who's Who in Alaskan Politics: A Biographical Dictionary of Alaskan Political Personalities, 1884-1974. Portland, OR: Binford \& Mort for the Alaska Historical Commission, 1977.

Belton, Howard C. Under Eleven Governors. Portland, OR: Binford \& Mort, 1977.

Frohman Trading Co. Alaska, California and Northern Indian Baskets and Curios, Wholesale and Retail. Portland, OR: Binford \& Mort, 1977. Reprint of: 1902 ed.

Hall, Betty L. Survival Education, Oregon. Portland, OR: Binford \& Mort, 1977.

Hatton, Raymond R. High Desert of Central Oregon. Portland, OR: Binford \& Mort, 1977. $3^{\text {rd }}$ ed by Binford in 1997.

Hauff, Steve and Jim Gertz. The Willamette Locomotive. Portland, OR: Binford \& Mort, 1977.

Knab, Otto Michael. In My Second Language. Portland, OR: Binford \& Mort, 1977.

McCall, Tom and Steve Neal. Tom McCall: Maverick An Autobiography. Portland, OR: Binford \& Mort, 1977.

Mee, Joseph W. Lucky Mee: [A Genealogy of the Mee Family]. Portland, OR: Binford \& Mort Publishers, 1977.

Powell, Larry D. Larry Powell's Big Book of Cake Decorating. Portland, OR: Binford \& Mort, 1977.

Pratt, Laurence. I Remember Portland, 1899-1915. Portland, OR: Binford \& Mort, 1977, (c) 1965 .

Ricks, Melvin. Melvin Ricks' Alaska Bibliography: An Introductory Guide to Alaskan Historical Literature. edited by Stephen W. and Betty J. Haycox. Portland, OR: Binford \& Mort for the Alaska Historical Commission, 1977.

Shahrokh, Bahman K. Inter-Relationships of the Evolutionary Systems. Portland, OR: Binford \& Mort, 1977.

\section{$\underline{1978}$}

Murphy, Florence. Sugarless Cookery: Family Style. Portland, OR: Metropolitan, 1978.

Hall, Betty L. Survival Education, California. Portland, OR: Binford \& Mort, 1978. 
Hatton, Raymond R. Bend in Central Oregon. Portland, OR: Binford \& Mort, 1978. $2^{\text {nd }}$ ed by Binford in 1986.

Olzendam, Dorothy J. Book For a Friend. Portland, OR: Binford \& Mort, 1978, c1976. $2 \mathrm{~d}$ ed.

Olzendam, Roderic Marble and Gordon Keith. It Came to Pass In the San Juan Islands. Portland, OR: Binford \& Mort, 1978. 1st ed. ix, 139 p. : ill. ; 23 cm.

Preston, Ralph N. Early Idaho Atlas. Portland:; Binford \& Mort, 1978. 2nd ed. Previously published as: Maps of early Idaho. Corvallis, OR: Western Guide Publishers, 1972.

Preston, Ralph N. Early Oregon Atlas: Early Forts, Old Mines, Old Town Sites. Portland:; Binford \& Mort, 1978. 2d ed. Previously published as: Historical early Oregon.

Schulmerich, Alma. Washington, D.C., A Walk Thru. Portland, OR: Binford \& Mort, 1978.

Tulloch, James Francis and Keith Gordon. The James Francis Tulloch Diary, 1875-1910:

The True Story of the Ups and Downs of James and Annie Tulloch and Their Nine Children, All of Whom Were Born and Raised on Orcas Island in Washington State's San Juan Islands. Portland, OR: Binford \& Mort, 1978. 1st ed. vii, 124 p., [1] leaf of plates : ill. ; $23 \mathrm{~cm}$.

Walker, Dick. Do Not Test Us: One Man's Ventures Into the Psychic World. Portland, OR: Binford \& Mort, 1978.

\section{$\underline{1979}$}

Atwood, Evangeline. Frontier Politics: Alaska's James Wickersham. Portland, OR: Binford \& Mort, 1979.

Barlow, Jeffrey G. and Christine Richardson. China Doctor of John Day. Portland, OR: Binford \& Mort, 1979.

Edwards, Margaret Watt. The Shands of Banffshire: A Family History. Portland, OR: Binford \& Mort, 1979.

Gardner, Robert. Thank God it's Friday. Portland, OR: Metropolitan Press, 1979.

Gunderson, Vivian D. Bible Learn and Do Book, Genesis Pupil's Book. Portland, OR: Binford \& Mort, 1979-. 
Howe, Carrol B. Ancient Modocs of California and Oregon. Portland, OR: Binford \& Mort, 1979.

Renner, Louis L. and Dorothy Jean Ray. Pioneer Missionary to the Bering Strait Eskimos: Bellarmine Lafortune, S.J. Portland, OR: Binford \& Mort for the Alaska Historical Commission, 1979.

Snyder, Eugene E. Portland Names and Neighborhoods: Their Historic Origins. Portland, OR: Binford \& Mort, 1979.

White, James Seeley. Diving for Northwest Relics: Identification and Dating of Bottles, Pottery, and Marine Hardware. Portland, OR: Binford \& Mort, 1979.

Warner, Mikell De Lores Wormell and Harriet Duncan Munnick. Catholic Church Records of the Pacific Northwest: St. Paul, Oregon 1839-1898: volumes I, II and III. Portland, OR: Binford \& Mort, 1979.

Ziggie.The Summer's Done. Portland, OR: Metropolitan Press, 1979.

\section{$\underline{1980}$}

The Oregon Trail: The Highway of the Pioneers to the Pacific Northwest: From Westport, Now Kansas City, to Oregon City By Way of Forts Kearney, Laramie, Bridger, Hall and Boise, Also the Sublette and Lander Cutoffs and the Bozeman and Applegate Trails and the Overland Rrail to the Sacramento Valley and the California Gold Mines. Portland, OR:; Binfords \& Mort, 1980. 1 map.

DuBose, L. A. and Rachel Sullivan. Revelation Discovered: The Code of the Book. Portland, OR: Binford \& Mort, 1980.

Frank, Gerry. Gerry Frank's Where to Find It, Buy It, Eat It, and Save Time and Money in New York. Portland, OR: Binford \& Mort, 1980. Biennial serial. 1st ed. (1980)-; 2nd ed. 1981.

French, Giles and Jane A Frees. Dear Dad, Love, Jane. Portland, OR: Binfort \& Mort, 1980.

Fries, Emil B. But You Can Feel It: A Statement of My Mother When I Returned Empty Handed Saying, "I Can't See It.” Portland, OR: Binford \& Mort, 1980.

Girard, May Shipton. The Cruel Cold Land: A True Story of People, A Place, A Time. Portland, OR: Metropolitan Press, 1980. 
Gunderson, Vivian D. Bible Learn and Do Book, Genesis Teacher's Manual. Portland, OR: Binford \& Mort, 1980-.

Hatton, Raymond R. High Country of Central Oregon. Portland, OR: Binford \& Mort, 1980. Reprinted by Binford \& Mort in 1987.

Hazzard, Flora Mae. The Ledge of Gold. Portland, OR: Binford \& Mort, 1980.

McKay, Harvey J. St. Paul, Oregon, 1830-1890. Portland, OR: Binford \& Mort, 1980.

Olzendam, Dorothy J. Summer on the Lake. Portland, OR: Binford \& Mort, 1980.

Van Veen, Ted. Rhododendrons in America. Portland, OR: Binford \& Mort, 1980, (c)1969. Reprinted by Binford \& Mort in 1986.

Young, Judy and Lu-sheng Chong. Rhododendrons of China: Species Descriptions and Key From volume III, Iconographia cormophytorum Sinicorum, Beijing Botanical Research Institute of Academia Sinica, 1974. Portland: Binford \& Mort, 1980.

\section{$\underline{1981}$}

Bever, Dale N. Northwest Conifers: A Photographic Key. Portland, OR: Binford \& Mort, 1981.

Preston, Ralph N. Early Washington Atlas: Overland Stage Routes, Old Military Roads, Indian Battle Grounds, Old Forts, Old Gold Mines. Portland, OR:; Binford \& Mort, 1981, (c)1974. 2nd ed.

\section{2}

Allyn, Stan. Heave To, You'll Drown Yourselves! Portland, OR: Binford \& Mort, 1982. $2^{\text {nd }}$ ed. printed in 1984. $3^{\text {rd }}$ ed. printed in $1982,4^{\text {th }}$ ed. in 1992.

Cordano, Vira. Levi Scott, Oregon Trailblazer. illustrations by Lloyd Brown. Portland, OR: Binford \& Mort, 1982.

Fogdall, Alberta Brooks. Royal Family of the Columbia: Dr. John McLoughlin and his family. Portland, OR: Binford \& Mort Publishers, 1982, 1978. 2nd (Bicentennial) ed.

Hatton, Raymond R. Pioneer Homesteaders of the Fort Rock Valley. Portland, OR:

Binford \& Mort, 1982. 
Keith, Gordon. Voices From the Islands: True Stories About Washington State's Fabulous San Juan Islands and Those Who Inhabit Them. Portland, OR: Binford \& Mort, 1982.

Mohan, Joseph M. The Grassland Poet. Portland, OR: Binford \& Mort, 1982.

Munnick, Harriet Duncan. Catholic Church Records of the Pacific Northwest. St. Louis Register. Volume I (1845-1868), St. Louis Register, Volume II (1869-1900), Gervais Register (1875-1893), Brooks Register (1893-1909). Portland, OR: Binford \& Mort, 1982.

Olzendam, Roderic Marble and Keith Gordon. Green Gold for America: The Life and Times of Roderic Marble Olzendam. Portland, OR: Binford \& Mort, 1982.

Rees, Helen Guyton. Shaniko: From Wool Capital to Ghost Town. Portland, OR: Binford \& Mort, 1982.

Sheller, Roscoe. Me and the Model T. Portland, OR: Binford \& Mort, 1982, c. 1965.

\section{$\underline{1983}$}

Easterling, Jerry. Country Chaff. Portland, OR: Binford \& Mort, 1983.

McCart, Dennie D. The Hope Truckline and 75 Miles of Women. Portland, OR: Binford \& Mort, 1983.

Qualman, Al. Blood on the Half Shell. Portland, OR: Binford \& Mort, 1983.

Rees, Helen Guyton and Ada Bell Guyton. "Schoolmarms.” Portland, OR: Binford \& Mort, 1983.

Rees, Helen Guyton. Shaniko People. Portland, OR: Binford \& Mort, 1983.

Preston, Ralph N. Early California Atlas. Portland, OR: Binford \& Mort, 1983. Northern ed., 2nd ed.

\section{$\underline{1984}$}

Dohnal, Karel. Yukon Solo. Portland, OR: Binford \& Mort, 1984.

Marshall, Don B. Oregon Shipwrecks. Portland, OR: Binford \& Mort, 1984.

McCart, Dennie D. Memories of Edenbrook Farm. Portland, OR: Binford \& Mort, 1984. 
Munnick, Harriet Duncan. Catholic Church Records of the Pacific Northwest: Oregon City Register (1842-1890), Salem Register (1864-1885), Jacksonville Register (18541885). Portland, OR: Binford \& Mort, 1984.

Van Voorhis, Ford. The Homesteaders of Chelan Butte. Portland, OR: Binford \& Mort, 1984.

\section{$\underline{1985}$}

Foley, Arthur L. You Can Cure Yourself. Portland, OR: Binford \& Mort, 1985.

Neils, Selma M. The Klickitat Indians. Portland, OR: Binford \& Mort, 1985.

Renner, Louis L. "Father Tom” of the Arctic. Portland, OR: Binford \& Mort, 1985.

Renner, Louis L. The KNOM/Father Jim Poole Story. Portland, OR: Binford \& Mort, 1985.

\section{6}

Clarke, Ann Brewster. Wade Hampton Pipes: Arts and Crafts Architect in Portland,

Oregon. Portland, OR: Binford \& Mort, 1986, (c)1985.

Munnick, Harriet Duncan. Catholic Church Records of the Pacific Northwest: Roseburg Register and Missions (1853-1911), Portland Register (1852-1871). Portland, OR: Binford \& Mort, 1986.

Rees, Helen Guyton. Guytons Galore: From French Huguenots to Oregon Pioneers. Portland, OR: Binford \& Mort, 1986.

\section{7}

Belford, Dale. Golf, the K.I.S.S. Philosophy: (Keep it Simple Stupid). Portland, OR: Metropolitan Press, 1987.

Minard, Eugene Watkins. Evolution of Gods: An Alternative Future for Mankind. Portland, OR: Metropolitan Press, 1987.

Scroggin, Martel. Wasco: An Epic Novel of Early San Francisco and the Untamed Oregon Frontier. Portland, OR: Binford \& Mort, 1987.

Munnick, Harriet Duncan and Stephen Dow Beckham. Catholic Church Records of the Pacific Northwest: Grand Ronde Register I (1860-1885), Grand Ronde Register II (18861898), St. Michael the Archangel Parish, Grand Ronde Indian Reservation, Grand 
Ronde, Oregon, St. Patrick's Parish, Muddy Valley, Oregon. Portland, OR: Binford \& Mort, 1987.

Notson, Adelia and Robert Notson. Stepping Stones: the Pilgrims' Own Story. Portland, OR: Binford \& Mort, 1987.

\section{$\underline{1988}$}

Bledsoe, Helen Wieman. Riverdale School, 1888-1988. Portland, OR: Binford \& Mort, 1988.

Boyd, Edward M. Alaska Broker. Portland, OR: Binford \& Mort, 1988.

Nichols, Dean. Kid on the River. Portland, OR: Binford \& Mort, 1988.

Praetorius, Henry. Immigrant Settler. Portland, OR: Binford \& Mort, 1988.

Preston, Ralph N. Early California Atlas: Southern Edition. Portland, OR:; Binford \& Mort, 1988. 2nd ed.

\section{$\underline{1989}$}

Allyn, Stan. Top Deck Twenty! Best West Coast Sea Stories! Portland, OR: Binford \& Mort, 1989.

Churchill, Samuel. Big Sam. Portland, OR: Binford and Mort Pub., 1989, c. 1965.

Flowers, Ralph. The Education of a Bear Hunter. Portland, OR: Binford \& Mort, 1989. 2nd ed.

Keeper, Berry. The Old Ones Told Me: American Indian Stories For Children. Portland, OR: Binford \& Mort, 1989.

Morgan, Louise. Westward H-O-O-O-o-o-o-o-o, the Olivers. Portland, OR: Binford \& Mort, 1989.

Munnick, Harriet Duncan and Adrian R. Munnick. Catholic Church Records of the Pacific Northwest: Missions of St. Ann and St. Rose of the Cayouse (1847-1888), Walla Walla and Frenchtown (1859-1872), Frenchtown (1872-1888). Portland, OR: Binford \& Mort, 1989.

Munnick, Harriet Duncan. Priest's Progress: The Journey of Francis Norbert Blanchet from the Atlantic Ocean to the Pacific in Three Parishes. Portland, OR: Binford \& Mort, 1989. 
Snyder, Eugene E. We Claimed This Land: Portland's Pioneer Settlers. Portland, OR: Binford \& Mort, 1989.

\section{0}

Ashcroft, Ida. The Book of the Century: St. James, the First 100 Years. Portland, OR: Binford \& Mort for St. James Evangelical Lutheran Church, 1990.

Gerber, Ham. Making Discoveries in Knots. Portland, OR: Binford \& Mort, 1990.

Lofquist, Thelma J. Frail Elders and the Wounded Caregiver. Portland, OR: Binford \& Mort, 1990.

Tetlow, Roger T. and Graham J. Barbey. Barbey: The Story of a Pioneer Columbia River Salmon Packer. Portland, OR: Binford \& Mort, 1990.

Thompson, Atlanta Georgia. Daughter of a Pioneer. Portland, OR: Binford \& Mort, 1990.

\section{$\underline{1991}$}

Allyn, Stan. The Day the Sun Didn't Rise! Portland, OR: Binford \& Mort, 1991.

Dusenbery, Harris and Wilson P. Ware. Ski the High Trail: World War II Ski Troopers in the High Colorado Rockies. Portland, OR: Binford \& Mort, 1991.

Gerber, Ham. Quick-and-Dirty Curve Handbook. Portland, OR: Binford \& Mort, 1991.

Snyder, Eugene E. Portland Potpourri: Art, Fountains \& Old Friends. Portland, OR: Binford \& Mort, 1991.

\section{$\underline{1992}$}

Birt, Anita. The House at Bridal Veil. Portland, OR: Binford \& Mort, 1992.

Fransen, Joean K. Gray \& Columbia's River. Portland, OR: Binford \& Mort, 1992.

Metcalf, George F. Making Waves In the Information and Space Age: Creativity and Management in the Electronic Era. Portland, OR: Binford \& Mort, 1992.

Ratliff, Donald E. Map, Compass and Campfire. Portland, OR: Binford \& Mort, 1992. 
Scroggin, Martel. The Moonlighters: A Fictional Account of Central Oregon's Vigilante Years, 1882-1884. Portland, OR: Binford \& Mort, 1992.

\section{3}

Garner, Ross. Donatus and Other Poems, 1951-1993. Portland, OR: Binford \& Mort, 1993.

Overholser, Marguariete. A Man Is a Man: A Hooker Family Saga. Portland, OR:

Binford \& Mort, 1993.

Overholser, Marguariete. On the Oregon Trail with the Ira Hooker Family, 1848.

Portland, OR: Binford \& Mort, 1993. Second edition printed in 1996.

Paschal, Jill Luan. On the Road With Jill. Portland, OR: Binford \& Mort, 1993.

Snyder, Eugene E. Aurora, Their Last Utopia: Oregon's Christian Commune, 1856-

1883. Portland, OR: Binford \& Mort, 1993.

\section{$\underline{1994}$}

Doerfler, Doris. A History of Sacred Heart Parish, 1893-1993. Portland, OR: Binford \& Mort for Sacred Heart Parish, 1994.

Nichols, Dean. The Copper Sands and Prince William Sound The N.P.M.W.A.R.A., the North Pacific Major World Air Route Area. Portland, OR: Binford \& Mort, 1994.

Nichols, Dean. A Sailor's Yarns and Observations: Two Cats for Puerto Rico. Portland, OR: Binford \& Mort, 1994.

Snyder, Eugene E. The Adventure of the Missing Brother. Portland, OR: Binford \& Mort, 1994.

\section{5}

Bellarts, Larry J. Bird With a Broken Wing. Portland, OR: Binford \& Mort, 1995.

Edwards, Margaret Watt. From Horse and Buggy to Men On the Moon. Portland, OR:

Binford \& Mort, 1995.

Hudrlik, Claudia Bergman and Kathleen Hirsch. Open Sesayou. Portland, OR: Binford \& Mort, 1995.

1996 
Edwards, Margaret Watt. Koom of the Tillamooks. Portland, OR: Binford \& Mort, 1996.

Snyder, Amanda. Amanda's Friends: Prints and Drawings by Amanda Snyder, American Artist, 1894-1980. Portland, OR: Binford \& Mort, 1996.

$\underline{1997}$

Curtin, Cáit. The Grand Lady of Fourth Avenue: Portland's Historic Multnomah Hotel. Portland, OR: Binford \& Mort, 1997.

Holmes, Willa and Anderson Benally. She Who Watches. Portland, OR: Binford \& Mort, 1997.

\section{$\underline{1998}$}

Dusenbery, Harris. North Apennines and Beyond: With the 10th Mountain Division. Portland, OR: Binford \& Mort, 1998.

Snyder, Eugene E. Mexican Notebook. Portland, OR: Binford \& Mort, 1998.

\section{$\underline{1999}$}

Bellarts, Larry J. Broken Wing II. Portland, OR: Binford \& Mort, 1999.

Kimo. Confuse's Says: “Franklin, my dear, I don't give a damn." Portland, OR: Binford \& Mort, 1999.

Marshall, Don. Eh, What's That You Said: Jargon of the Sea. Portland, OR: Binford \& Mort, 1999.

\section{$\underline{2000}$}

Gray, James M. and Shawn Boutwell. How to Master the English Bible. Portland, OR: Binford \& Mort, 2000.

Keeland, Ellen and Lloyd Keeland. The Lusty Life of Loon Lake Lloyd: World War II Marine, Logger, and Resort owner. Portland, OR: Binford \& Mort, 2000.

Keeland, Ellen and Lloyd Keeland. The Lusty Life of Loon Lake Lloyd: World War II Marine, Logger, and Resort Owner: His True Life Stories. Portland, OR: Binford \& Mort, 2001, (c)2000. 2nd ed. 
Roberts, Hugh R. Poems of My Time: Life In the San Juan Islands. Portland, OR: Binford \& Mort, 2000.

\section{$\underline{2001}$}

Bellarts, Larry J. Red-Tailed Peacemaker. Portland, OR: Binford \& Mort, 2001.

Byrd, Dean H. and Stanley R. Clarke and Janice M. Healy, comps. Oregon Burial Site Guide. Portland, OR: Binford \& Mort, 2001.

Churchill. Big Sam. Portland, OR: Binford \& Mort, 2001.

Garner, Ross. The Bridge to China: Poems, 1993-2000. Portland, OR: Binford \& Mort, 2001.

Nelson, Sonja. The Pacific Coast Rhododendron Story: The Hybridizers, Collectors and Gardens. Portland, OR: Binford \& Mort, 2001.

Olzendam, Roderick. It Came to Pass in the San Juan Islands. Portland, OR: Binford \& Mort, 2001.

Renner, Louis L. Father Tom of the Arctic. Portland, OR: Binford \& Mort, 2001.

Walker, Dick. Do Not Test Us. Portland, OR: Binford \& Mort, 2001.

\section{$\underline{2002}$}

Crittenden, Katharine Carson. Get Mears! Frederick Mears, Builder of the Alaska Railroad. Portland, OR: Binford \& Mort; Anchorage, Alaska: Cook Inlet Historical Society, 2002.

\section{$\underline{2003}$}

Gibson, John Merrill. Growing Up On the Lewis \& Clark Trail: A Book of Regional Art and Childhood Memories in Cathlamet on the Columbia. Portland, OR: Binford \& Mort, 2003.

Halvorson, Clara Elizabeth. A Heart for Healing. Portland, OR: Binford \& Mort, 2003.

Snyder, Eugene E. Travels, Stories \& Characters From an Author's Notebooks. Portland, OR: Binford \& Mort, 2003.

\section{$\underline{2005}$}


Satern, Stella Bellingham. The Nehalem River Valley: Settling the Big Timberland. Portland, OR: Binford \& Mort, 2005. $1^{\text {st }}$ ed. 488 p. : ill. ; $23 \mathrm{~cm}$. Stories about the pioneers who settled the Oregon wilderness of the Nehalem River valley, from the $1860 \mathrm{~s}$ through the twentieth century.

\section{Undated Imprints}

Cox, Ross. Adventures on the Columbia. Portland: Binfords and Mort, undated.

Gardner, Walter H. The Perfect Advertisement; or, The Biography of Humphrey Hangapple. Portland, OR: Metropolitan Press, undated.

Atkeson, Ray. Washington and Oregon in Color: Twenty-four Natural Color Photographs. Portland: Binfords \& Mort, undated.

Atkeson, Ray. Twenty-four Views of Oregon and Washington in Color. Portland, OR: Binfords \& Mort, undated.

Keller, Paul and Sam Raddon. Portland Vignettes. Portland, OR: Metropolitan Press, undated. Oregon Journal ed.

Washington in Pictures: One Hundred and Eleven Views from Every section of the State of Washington in Rotogravure. Portland, OR: Binfords \& Mort, undated.

Meany, Edmond S. Mount Rainier: A Record of Exploration. Portland, OR: Binfords \& Mort, undated. Listed as 1916, but this is impossible since Binfords was not used until after 1937.

Moore, Janet. Where Beauty Is. Portland, OR: Metropolitan Press, undated. 